\title{
Gilberto Mariotti
}

\author{
$\mathrm{Wp} / \mathrm{Wp}$ \\ Um relato crítico \\ da experiência de \\ Workplace/ Werkplaza
}

Dissertação apresentada ao Programa de Pós-Graduação em Artes, Área de Concentração Artes Plásticas, Linha de Pesquisa Poéticas Visuais, da Escola de Comunicação e Artes da Universidade de São Paulo, como exigência para obtenção do título de Mestre em Artes, sob orientação da Profa. Dra. Ana Maria Tavares

março de 2009 

Banca Examinadora

São Paulo, de 2009 

$\mathrm{Wp} / \mathrm{Wp}$ 

Para minha família. 
"Não, eu não gosto de trabalhar. Preferiria vagabundear por ai e pensar em todas as boas coisas pra se fazer. Não gosto de trabalhar - ninguém gosta --, mas gosto do que há no trabalho, - a chance de encontrar a si mesmo. Sua própria realidade - para si, não para outros - o que ninguém mais pode saber. Eles podem apenas ver o resultado, mas nunca dizer o que realmente significa."

Em O coração das trevas, de Joseph Conrad 
"No, I don't like work. I had rather laze about and think of all the fine things that can be done. I don't like work, - no man does - but I like what is in the work, - the chance to find yourself. Your own reality - for yourself, not for others - what no other man can ever know. They can only see the mere show, and never can tell what it really means."

From The heart of darkness, by Joseph Conrad 


\section{Abstract}

In a place called "workplace", a site oriented art work, wich I called Workplace/Werkplaza, took place. This masters degree project, written as a narration, means to understand some of the characteritics of the site created by this experience, that was generated in the relation between some reflections about the project and the office building called "Workplace". In the narration, besides that which could have happened in the process of the work and in the work itself, a critical reading of the Mendonça law -that which made possible the creation of Artenexo, Workplace's cultural space- and an aproximation to part of Cildo Meirele's work as a case study for the analysis of Workplace/Werkplaza, are offered. There's also an attempt to problematize this work's photographical registers, as well as the form of the narration itself, as an outspread of the work. 
Resumo

Em um lugar chamado "lugar de trabalho", ocorreu o trabalho de arte elaborado especificamente para este lugar, que chamei de Workplace/Werkplaza. Esta dissertação, em forma de relato, tem por objetivo compreender alguns aspectos do lugar constituído por esta experiência, que se deu na relação entre algumas reflexões e o edifício de escritórios em que ocorreu a intervenção, o "Workplace". Pelo relato, além do que pode ter ocorrido durante o processo de trabalho e no trabalho em si, passa uma leitura crítica da Lei Mendonça, que possibilitou a criação do Artenexo, espaço cultural de Workplace, além de uma aproximação com parte da produção de Cildo Meireles como estudo de referência para a análise de Workplace/Werkplaza. Há também a tentativa de problematização do registro fotográfico deste trabalho, assim como sobre a própria forma do relato enquanto seu desdobramento. 

Sumário:

Introdução........................................................pg 15

1 Início.............................................................pg 19

2 Discurso como contexto.................................pg 27

3 Entorno.......................................................pg 69

4 Descrição.........................................................pg 87

5 (Fiç̧ão)...............................pg 95

4.1 Processo e fracasso................................pg 151

4.2 Considerações finais.............................pg 163

6 Registro como lugar.............pg 175

4.3 Releitura.................................................pg 191

Referências Bibliográficas................................pg 210

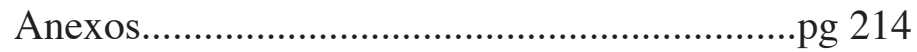





\section{Introdução}

Workplace, Shoppingplace, Shoppingplaza, workplaza, workshop, werkplace, shoppingplatz, werkplaza. Onde se trabalha, onde se compra. O lugar de trabalho, o lugar de compras. O lugar da compra. O lugar do trabalho.

O lugar se chama Workplace. Das implicações desta afirmação, que poderia estar aí despretensiosamente, todos meus estudos até agora não deram conta. Nem a afirmação de que se trata mesmo de um lugar escapa de questionamento. E um lugar nomeado "lugar de trabalho", ou "lugar do trabalho", ou "lugar trabalho" como objeto de estudo, poderia demandar toda uma teoria econômica, ou da economia como produtora de semântica, que obviamente não é objetivo nem o objeto deste trabalho. Devo apontar para uma tarefa muito menos pretensiosa: compreender alguns aspectos do lugar que a experiência contida neste relato definiu. Esta experiência constituída na relação que se estabeleceu entre nossas reflexões e o funcionamento do edifício Workplace. Da construção de uma forma, como reação às formas nas quais ocorreu o que passei a chamar de intervenção, por falta de denominação mais eficiente. E o nome desse edifício foi porta de entrada para estas reflexões. 

Pode incomodar, em uma dissertação de mestrado, a opção pelo uso de primeira pessoa, na forma de relato ou descrição processual, pelo risco, sempre iminente, de que se naturalize o lugar do sujeito.

Pois que a construção do sujeito (este que sofre impressões, que constrói juízos) se dá, neste caso, pela própria narrativa. Assim, este "eu" que vive aqui e que apresentará os pensamentos e reflexões e os objetos, não é quem conta ao leitor sobre tudo, como se de fora da experiência. É antes um construto da experiência da leitura. Mesmo o narrador que chamamos de onisciente, só pode saber da própria narrativa, que é o que seu lugar lhe deixa ver para que narre. $\mathrm{E}$ está aí a condição de uma dissertação sobre a obra: tudo o que estiver aqui só pode ser obra da narrativa.

O desafio seria, então, ver antes a narrativa como lugar de trabalho, para depois vermos como o Workplace remolda o lugar de trabalho que é a narrativa e vice-versa.

Daí pode vir ainda um outro risco: o de construir, protegido pela categoria "escrita de artista", uma narrativa que pareça almejar o rótulo de literatura. Mas ocorre que este lugar - o da criação do sujeito, o lugar livro, texto, dissertação, e enfim a narrativa - é o único em que algumas indagações, ao serem lidas, podem tomar forma. E é por esta possibilidade que se lê este relato. 



\section{Início}

De início, fomos chamados como dois artistas, Carlos Pires e eu, que fariam duas exposições. Só aceitei o convite quando soube que poderíamos desenvolver em conjunto algo que ocupasse todo o espaço das duas salas contíguas reservadas aos eventos. Mais do que trabalhar com alguém com quem poderia discutir, tratava-se de descolar-se de um padrão incômodo de formato expositivo que havia se tornado comum: espaços previamente delimitados a serem preenchidos por algumas peças no chão ou na parede, acompanhadas de etiqueta e créditos. $\mathrm{O}$ curador era um amigo em comum, e haveria algum dinheiro para a produção do trabalho. Aceitamos. 

Chegamos ao edifício ao mesmo tempo em que o poder público retirava do bairro seu maquinário. A Rua Funchal havia sido reformulada, aberta em toda sua extensão, e suas calçadas ainda esperavam acabamento que voltasse a cobrir as tubulações de esgoto. A frente do Workplace era um grande buraco revirado, em parte coberto por tapumes que possibilitavam o acesso à entrada principal. Isso, no entanto, não parecia alterar em nada a relação do prédio e seu entorno. Sua entrada, que dispõe de catracas e um mezanino que abriga o pessoal da segurança, não parecia convidar o pedestre ao espaço interior. Servia apenas de filtro para as empresas que ocupavam seus conjuntos. Um destes conjuntos, no entanto, havia sido reservado temporariamente para exposições periódicas: o Espaço ArteNexo, criado a partir da Lei Mendonça de incentivo fiscal.

Todo o entorno urbanístico do edifício poderia ser lido como um discurso razoavelmente coeso, formado a partir de um padrão repetido pelos nomes que vários empreendimentos similares a este tinham em comum, compostos por um uso indiscriminado de meia dúzia de termos banais em línguas estrangeiras, e que recombinados, compunham novos nomes: Workplace, Shoppingplace, Shoppingplaza etc. Talvez Carlos nem se lembre disso, mas em algum ponto da elaboração do trabalho, passamos a trocar randomicamente os termos por outros, em outras línguas, ironizando sua aleatoriedade. Daí veio o nome que resolvi oficializar quando elaborava o projeto de mestrado, por achar que funcionava como um rebatimento revelador deste tipo de apropriação: Workplace/Werkplaza.

De antemão nos pediram que resolvêssemos o folder. "Resolver o folder" significava fornecer as reproduções dos trabalhos que seriam expostos. Havíamos optado por entender primeiro os contextos que envolviam Workplace, 
1: Este mesmo tipo de associação entre um formato e outro me ocorreu ao pesquisar algumas dissertações e teses em poéticas visuais. Nas prateleiras da biblioteca da ECA, muitos destes trabalhos se apresentavam num formato que me parecia ambíguo, algo entre um livro encadernado de modo mais tradicional e um livro de ata, comumente utilizado por empresas e instituições. Sua edição não se dá em cadernos. É feito no tamanho padrão das folhas A4, apenas sobrepostas, como uma reprodução em xérox. $\mathrm{O}$ verso destas folhas não é aproveitado. Esse formato, desde logo, me interessou como meio. Parece revelar confiança apenas no conteúdo impresso, como se este o livrasse de qualquer conexão com a forma em que acontece.Assim pus-me a pensar em uma forma que pudesse explorar os dois formatos. As páginas à esquerda poderiam conter notas e textos que ocupam o lugar de objeto, enquanto o relato correria pelas páginas à direita.

2: O folder pode ser visto em anexo. 
e desenvolver, a partir de alguma discussão, um trabalho que, neste ponto do processo, tinha resultados imprevisíveis. Logo, não faria sentido trabalhar com a hipótese de um registro fotográfico que viesse antes da abertura da exposição. Mas a burocracia do processo nos obrigava, senão a fornecer reproduções, ao menos a formatar o folder previamente, para que estivesse pronto para a abertura. $\mathrm{E}$ foi o que fizemos. Foi-nos dado como referência um folder feito para o programa de exposições anterior. Um pequeno bloco retangular, com uma aba na extremidade que servia para lacrá-lo, possibilitando seu envio pelo correio. Foi Carlos que associou o formato externo do impresso ao carnê que recebia todos os meses para o pagamento de um apartamento financiado ${ }^{1}$. E isto nos levou diretamente ao vínculo do espaço expositivo com seu financiamento pela lei de incentivo fiscal. Assim, as páginas internas do folder foram recompostas como as folhas destacáveis para o pagamento em vias, típicas dos carnês utilizados para o pagamento do IPTU, Imposto Predial Territorial Urbano. Os dizeres que indicam o conteúdo a ser preenchido nos caixilhos que compõem a página foram substituídos por trechos extraídos de Mínima Morália, de T. Adorno².

Este primeiro resultado não pretendia ser um trabalho autônomo, nem sequer parte do que pensávamos em realizar como intervenção. Mesmo assim serviu de base para nossa organização enquanto dupla de trabalho que propunha colaborações aos demais envolvidos. O programador visual foi chamado a repensar a diagramação e o curador elaborou o texto, que obrigatoriamente deveria integrar o folder, a partir das demandas conceituais deste novo formato. Colocava-se como um primeiro posicionamento sobre a natureza daquele espaço, fundado pela possibilidade de otimização do aproveitamento de tributos. 

Até então eu não dava tanta importância ao papel desempenhado pela lei como parte do contexto que tentávamos desvendar, a ponto de investigar suas formas jurídicas. Nosso foco conceitual era como imperava ali uma idéia de trabalho que parecia engolir e adaptar algumas possibilidades de intervenção, já que havia se aberto naquela estrutura um espaço reservado ao produto cultural que seria apropriado simbolicamente pelo sistema de valores que representava aquela arquitetura. Ou seja, inicialmente havia a percepção deste edifício como uma metáfora da relação entre cultura e arte em sua dinâmica mais recente. 
1: Parto da concepção de Foucault: "O discurso é esse conjunto regular de fatos linguisticos em determinado nível, e polêmicos e estratégicos em outro." Em: FOUCAULT, M. "A Verdade e as Formas Jurídicas". Rio de Janeiro: Nau, 2005 


\section{Discurso como contexto}

Ao rever esta primeira abordagem do que pensávamos ser um elemento não estrutural do contexto de Workplace, me propus a pesquisar os mecanismos dessa lei e suas possibilidades de apreensão e utilização social. Minha leitura do texto da lei, como disponibilizado pela prefeitura, foi se fazendo como um exercício de análise de discurso, mas entendendo o discurso como não apenas um conjunto de fatos lingüísticos ligados entre si por regras sintáticas de construção, mas em um outro nível, fatos polêmicos, estratégicos, políticos ${ }^{1}$.

Se a partir daqui meu relato começa a destoar um tanto do que já se leu, é porque se trata de um relato de leitura. Falo de algumas reflexões sobre a lei que não posso deixar de fora do trajeto, por serem já parte da experiência que, tempos depois, fez-me rever criticamente a memória que havia produzido do lugar e dos espaços com que trabalhávamos. Com efeito, devo registrar estas minhas primeiras impressões, mesmo que depois a continuação do relato possa desmenti-las. 

Um especialista talvez dissesse que o questionamento da forma deste texto advém da falta de treino para as formas jurídicas e de intimidade com os textos que regram. Haveria de ter razão. Foi com dificuldade que absorvi os significados contidos no texto. Mas não por que seja enfadonho, nem por conter alguns termos com os quais o trato cotidiano que têm os profissionais do direito poderia aproximar, mas pela falta de nexo lógico entre os parágrafos, pela volubilidade das afirmações, e principalmente pelo seu ritmo sincopado. Afinal, minha experiência de leitura habituou-me ao pensamento linear, à desenvoltura das ações e cenas dos textos de ficção, ao nexo conceitual que serve de cola aos textos teóricos.

Esta forma jurídica se apresenta como que desprovida de introdução em si mesma. Sua interpelação ao leitor se dá desajeitadamente, através de vários inícios, o que desarmoniza, no sentido clássico, seu todo. A fragmentação é sua principal condição de gênese. Sua edição se dá alternando avanço e retrocesso, num andar conflitante. Contudo, é desta maneira que ganha coerência, já que o conformar-se de modo fragmentado a torna mais eficiente em seus objetivos.

Seria a Lei Mendonça parte disso a que chamamos comumente de contexto? Contextualizar é correr o risco de produzir um panorama, um cenário idealizado a partir do trabalho de arte. Formar a imagem de um todo para que este possa acolher nossas melhores expectativas em relação à potência dos desdobramentos da intervenção. Talvez seja possível situar, não o trabalho em um contexto representável (uma imagem), mas o leitor, tornando visível o lugar ocupado pelo sujeito em meio aos discursos que produzem, a meu ver, o contexto em que se inseriu e se insere ainda WorkPlace/WerkPlaza. 
Lei Mendonça - Lei de incentivo à cultura da Cidade de São Paulo

Lei $\mathrm{n}^{\circ} 10.923$ de 30 de Dezembro de 1990

A Lei $10.923 / 90$ prevê a associação de recursos privados com os do Município de São Paulo, por meio de incentivos fiscais, com a finalidade de patrocinar iniciativas culturais de todos os gêneros.

Para se valer dos benefícios fiscais, os projetos devem ser encaminhados para aprovação de uma comissão, formada por membros indicados pela Secretaria Municipal da Cultura e por Entidades Culturais, a qual também será responsável pelo acompanhamento do desenvolvimento desses projetos.

Prazos de inscrição, com a apresentação de projetos, são publicados no Diário Oficial do Município nos meses de fevereiro, junho e setembro.

A Lei Mendonça ( $\left.n^{\circ} 10.923 / 90\right)$ oferece como benefício fiscal à pessoa física ou jurídica a dedução de $70 \%$ do valor investido no projeto, até o limite de $20 \%$ do total devido de ISS ( Imposto Sobre Serviço ) e IPTU ( Imposto Predial e Territorial Urbano ).

O contribuinte pode lançar a diferença entre o investimento e o desconto do imposto, a seu favor, em outros pagamentos de impostos, num prazo de 24 meses, podendo nesse período resgatar o total de descontos a quem tem direito. 
De qualquer forma, o que não posso dizer sobre esta lei é que ela origina situações. Ao contrário, escuto-a como o anunciar de algo já em andamento. Seu papel é o de responder a uma demanda, um imperativo. De, nesse sentido, realizá-lo. Torná-lo visível, inteligível, oferecendo-lhe contornos, dando-lhe forma. 

Cultura como jogo

Uma primeira pergunta: como a normatização da cultura pode ela mesma influir na dinâmica cultural? Ora, uma lei para cultura se estabelece como fato cultural duplo, ação e meta-ação cultural, já que atua no próprio sistema ao qual pertence, no momento mesmo em que passa a valer. Contudo, esta idéia de contínuo reposicionamento em relação à própria ação, em que sujeito e objeto substituem-se continuamente, não toca a elaboração da lei nem conduz a consciência de que o que se propõe como regra também é fato cultural. Este discurso utiliza a forma indeterminada, impessoal, mascarando a existência mesma de um sujeito, além de sua responsabilidade sobre o que é enunciado. $\mathrm{O}$ ponto de vista é oculto e o que se vê é dado como objeto opaco.

Como lei voltada para política cultural, a Lei Mendonça visa a simples funcionalização da cultura, ou seja, pretende achar um lugar em que a concepção de cultura se encaixe num mais amplo sistema de produção social e econômica. Mostra-se, através do ato de legislar, como se estivesse de fora desta estrutura, ou seja, de um ponto de vista pretensamente neutro ou externo à própria sociedade. Claro que este ponto de vista é, além de uma abstração, impossível na realidade social, mas o discurso jurídico assim se coloca para que se resguarde a ilusão de isenção. Tratase na verdade de uma naturalização do Estado. Este deve, através dessa forma rígida, existir antes de tudo aquilo sobre o que se legisla, como se posicionasse fora da História. Como se legislar não fosse também agir, mas apenas mediar ações, organizá-las. No entanto, as práticas judiciárias são 
Art. $1^{\circ}$ - Fica instituído, no âmbito do Município de São Paulo, incentivo fiscal para a realização de projetos culturais, a ser concedido a pessoa física ou jurídica domiciliada no Município. 
formas pelas quais nossa sociedade definiu tipos de subjetividades, formas de saber. E isto se dá através da definição de fazeres muito específicos. A lei Mendonça é isto: um manual que define fazeres, que por sua vez impulsionam e organizam um jogo.

Do empreendedor

A idéia de um ponto de vista que omite a si mesmo enquanto agente, transparece na própria estrutura rítmica do texto. A impressão inicial, aliás, é de que se trata de um fragmento de texto, já que este parece começar por práticas derivadas de pressupostos ocultos. Os termos e palavraschave para sua compreensão já chegam dessa maneira, como que subentendidos. Provêm da dinâmica vigente na atual política cultural, estabelecendo fazeres conectados aos fazeres instituídos. Por isto o texto da lei se mostra submisso a necessidades ou demandas prementes, urgentes de uma prática que não é posta em questão. O leitor deve simplesmente conhecer agora como o jogo será jogado, por quais regras, daqui por diante. Este tipo de condução talvez seja, até certo ponto, característica de todo texto legislativo no sentido de que faz parte de todo um código anterior. Mas é significativo o fato de, no caso de uma lei específica para cultura, apresentarem-se certos termos na forma de produtos acabados, sem que se revelem suas próprias costuras. Como se elabora um "projeto cultural"? Ou antes, o que vem a ser um "empreendedor cultural"? Alguns objetivos ou intenções, que não chegam a cumprir papel definidor, 
2: Em decreto regulamentador posterior (na versão de 2005), encontrase uma proposição de projeto cultural, mas apenas referente àquilo que nele ou através dele deve-se "promover, preservar e estimular". Ou seja, um norte valorativo.

$1^{\mathrm{o}}$ - O incentivo fiscal referido no "caput" deste artigo corresponderá ao recebimento, por parte do empreendedor de qualquer projeto cultural no Município, seja através de doação, patrocínio ou investimento, de certificados expedidos pelo Poder Público, correspondentes ao valor do incentivo autorizado pelo Executivo. 
aparecerão mais adiante no Decreto Regulador ${ }^{2}$.

Não há progressão lógica dos artigos em relação a temas ou assuntos. Às vezes os artigos estão ligados entre si por alguma idéia corretiva ou de complemento em relação ao artigo anterior. Como se não houvesse tempo para correção. Parece predominar uma confiança na solução de quaisquer questões posteriormente pela própria prática e funcionamento da lei.

Os atores são apresentados como parte de uma situação local e de muita especificidade. Mas trata-se de uma questão local apenas no sentido de que o público que será sujeito destas ações pertence a um determinado lugar social e é possuidor de competências específicas para o desempenho das atividades agora regulamentadas. E é este público que demanda uma decisão. Reconhece a si mesmo rapidamente. Identifica e decodifica facilmente estes termos previamente definidos e já tem experiência em utilizá-los. Os recursos são da cidade, mas os destinatários se definem por este tipo de conhecimento; um saber de classe.

Estes termos tornaram-se senso comum através de um determinado uso, originários de uma cultura de mercado, de uma linguagem empresarial que se impõe em todas as instâncias sociais. O empresário é o destinatário final desta "missiva".

Daí o uso positivo do termo "empreendedor" (e não empresário, homem de negócios, executivo ou administrador) e o esclarecimento mais do que rápido sobre a maneira de ressarcimento. Estabelece-se o papel de troca através do qual os negócios se efetuarão ("certificados expedidos pelo poder público"). É um esclarecimento dado no lugar de prioridade reservado a um objetivo de mensagem, um vínculo primeiro e fundamental. 
$2^{\circ}$ - Os portadores dos certificados poderão utilizá-los para pagamento dos impostos sobre serviços de qualquer natureza - ISS e sobre a propriedade predial e territorial urbana IPTU, até o limite de $20 \%$ (vinte por cento) do valor devido a cada incidência dos tributos.

$3^{\circ}$ - Para o pagamento referido no parágrafo anterior, o valor de face dos certificados sofrerá desconto de 30\% (trinta por cento).

Art. $2^{\circ}$. Para os efeitos deste decreto, considera-se:

I - projeto cultural ou projeto: a iniciativa cultural a ser apresentada e realizada, prioritariamente e em sua maior parte, no âmbito territorial do Município de São Paulo, e que esteja em conformidade com a respectiva política cultural, especialmente no que se refere a promover, estimular e preservar:

a) a produção cultural e artística, preferencialmente a que valorize iniciativas locais;

b) a geração de empregos na área cultural do Município; 
Assim, não se discute o quê, nem como, nem o porquê. Estabelece-se prioritária e inicialmente em troca de quê. Ou por quanto, por qual porcentagem.

Estes termos não precisam ser explicados por serem sinais decodificáveis no âmbito de certas "culturas". O termo cultura, se assim utilizado, é referente a um ideário comum de um determinado grupo, e faz parte da ideologia deste grupo acreditar que seu ideário contém valor universal.

Também os termos relativos à cultura são dados por subentendidos. Dividem espaço com itens relativos a fatos conseqüentemente econômicos: desenvolvimento do turismo, geração de empregos e aquisição de ingressos. Todos sabemos o que é um posto de trabalho, mas poucos de nós podem elaborar com desenvoltura e prontidão uma definição de "produção artística" ou "pluralismo cultural" ou ainda "produção inovadora". Assim há valores implícitos sujeitos a projeção, a serem preenchidos por necessidades mais práticas. 
c) o desenvolvimento do setor de turismo cultural do $\mathrm{Mu}$ nicípio;

d) o acesso às fontes de cultura e o pleno exercício dos direitos culturais pelo cidadão;

e) o apoio, a valorização e a difusão, no Município de São Paulo, do conjunto de manifestações culturais e respectivos criadores;

f) a proteção das expressões diversificadas, responsáveis pelo mais amplo pluralismo cultural;

g) a salvaguarda, a sobrevivência e o florescimento dos modos de criar, fazer e viver dos habitantes da Cidade;

h) os bens materiais e imateriais que compõem o patrimônio artístico, histórico e cultural da Cidade;

i) a produção e difusão de bens culturais de valor universal, formadores e informadores de conhecimento, cultura, ciência e memória;

j) a produção cultural espontânea, que estimule o processo criativo e o acesso a manifestações comunitárias;

1) a produção inovadora;

m) a aquisição de ingressos para eventos culturais realizados no Município; 
Valores do empreendedor

Muito a se promover, estimular e preservar. Contudo há um item, o "i", que se sobressai por um universalismo supostamente insuperável da produção cultural paulista: "bens culturais de valor universal, formadores e informadores de conhecimento, cultura, ciência e memória". Ou seja; tudo o que se sabe, o que se vive, tudo o que se pode prever e lembrar. E que vale para todos.

Nesta universalização se fundamenta o caráter mais visivelmente ideológico da lei; para que qualquer indivíduo possa tomar o lugar de sujeito que se denomina aqui de empreendedor, ou seja, tornar-se apto a participar do jogo, é necessário que tenha tais valores "culturais" como pressupostos. Questionar a natureza destes valores, sua origem, perguntar por sua formação histórica ou questionar-se acerca de sua universalidade já configura inaptidão para sua participação. 

Assim podemos dizer que a lei é uma espécie de manual que define novas regras do jogo, ou um novo jogo, para jogadores já experientes. Estes jogadores agora serão os novos sujeitos da ação, através de fazeres e regras que definem (estas sim) a cultura, e são também definidas por ela. Este modo de fazer e de ser significa submeter-se a uma competição, a um jogo, onde a classe empresarial é o júri. Por sua vez, este manual é, enquanto texto, espaço de jogo de suas próprias contradições, que fundamentam as do jogo político dos indivíduos. Por isso a Lei pode ser vista como parte constitutiva do espaço no qual WorkPlace/WerkPlaza tenta intervir.

Para que o jogo flua, é preciso que a lei forneça valores e modelos de projeção e identificação, como se parte de um sistema, que sempre aparentará ter sido criado para cada um (indivíduo), mas que é constantemente reformulado para qualquer um. Por isto o clima de pressa. Trata-se de uma formulação prática para algo sempre muito anterior e nunca declarado em sua totalidade.

$\mathrm{O}$ empreendedor, personagem desta narrativa altamente interativa, é herói de nobre linhagem, oriunda dos mitos mais surrados: o "vencedor", aquele que "se fez na vida sozinho", etc. Todos ainda em uso por vários outros discursos, ainda necessários.

Quem quer que ocupe este lugar, para os efeitos da lei, deverá: conceber e organizar um projeto para que este seja submetido à aprovação do poder público e depois do empresário; não integrará oficialmente grandes instituições; deverá apresentar novas formas de atuação cultural que seduzam o investimento do empresário. Positivadas, estas condições que antes pareciam adversas, passam a ser descritas como iniciativa, independência e inovação. Tempos atrás, o mais comum seria a defesa de valores 

como tradição, solidez e previsibilidade, em oposição a estes citados anteriormente. Isto por que o capital atual tem a flexibilização como competência mais importante para seu desenvolvimento. A partir da normatização, enquanto discurso, da chamada "Globalização", o conceito de empreendedorismo se torna corrente, mostrando-se como condição para a inclusão tanto dos indivíduos como das próprias administrações públicas nas novas dinâmicas do capitalismo. Esta nova condição prevê tentativas de atrair o capital, cada vez mais fugidio e volátil, por quaisquer meios necessários. Para o Estado, isso significa limitar-se a regular as atividades do capital corporativo, o que neste caso fica mais visível no tocante à natureza do planejamento imobiliário em que está fundado Workplace.

No plano da regulamentação, o Estado parece transferir sua própria condição de subordinação ao capital para as pequenas iniciativas. Pelo seu posicionamento no jogo econômico atual e por assumir para si o papel mediador de um jogo onde interesses privados e públicos se opõem, o Estado se coloca como "empreendedor". Apresenta-se ele mesmo como assujeitado pelas circunstâncias econômicas e políticas das quais é participante.

O discurso em conluio com o capital que funcionava a partir de ficções baseadas nas noções de pátria, estado, tradição é substituído por outro, movido pelo capital, agora ele próprio fictício. 
3: Como produtora de discurso hegemônico, a propaganda tem como condição primeira, a competência de se auto-naturalizar, ou seja, de se apresentar como discurso espontâneo de um todo obscuro da sociedade. Assim, o fortalecimento da marca do investidor aparece como o "efeito natural" de uma ação que por administrar bens chamados culturais, merece retorno, quase como uma cortesia que venha em troca da generosidade dos investidores. Como se a ação da publicidade fosse um mal necessário para que grandes coisas fossem realizadas. Como se publicidade não pudesse ser reconvertida em valor, contabilizada como ganho. 
Das possibilidades do jogo

Em oposição à figura do Estado centralizador, e em favor de um maior controle por parte dos cidadãos de seus impostos, justifica-se que o empresário possa descontar do imposto que deve à cidade o correspondente em certificados emitidos pelo poder público a uma certa quantia a ser investida em determinado projeto cultural. Ou seja, converter um tributo imposto em processos nos quais o próprio poder público deveria investir. Mas há um percentual do imposto previsto que deixa de ser pago pelo empresário à cidade e que ele retém.

Este percentual, no entanto, representa apenas um ajuste em termos de investimento para o financiador do projeto. O que realmente torna o mecanismo lucrativo é a possibilidade que este oferece de exploração das últimas técnicas de publicidade desenvolvidas por esta nova "disciplina" dos meios de propaganda: o chamado "marketing cultural" 3 . Não acho que tenha sido o caso do ArteNexo, espaço cultural do Workplace, talvez por certa inabilidade de condução ou falta de prioridade, mas a exploração das leis de incentivo para a criação de instituições culturais ligadas a grandes capitais, tanto produtivos como especulativos, tem se consolidado como bom investimento, na medida em que aparatos culturais como institutos, centros e fundações exercem na prática a função de produtores e difusores de imagem.

A criação de um instituto cultural pode possibilitar um remanejo constante de recursos que estariam de outro modo "perdidos" para a administração pública. Tais recursos são investidos em manifestações culturais (que 
4: Assim o capital financeiro, no caso do investidor ser um banco, por exemplo, controla as necessidades de produção de seus "clientes", já que dele dependem seus negócios, suas possibilidades de crédito, suas operações relativas a trânsito de capitais, ao mesmo tempo em que opera também com suas produções simbólicas, já que controla os produtos culturais que estes "clientes" consomem. O que mantém estes dois pólos girando entre si é uma produção constante de representações ratificadoras, interligadas e interativas. Acreditar-se como possuidor de certas quantias (hoje representações sem lastro) é acreditar-se como pertencente a certa classe ou grupo que consome um certo pacote de produtos necessários a um certo estilo de vida. Ou seja, uma série de abstrações reiteradas umas pelas outras, em função da manutenção de todas, e deste modo, da manutenção do poder do pequeno grupo de agentes beneficiados. 
na maioria das vezes trazem consigo um apelo comercial infundido pela indústria cultural) que através de meios de registro e informação, são reformulados para serem produtos, distribuídos pelo aparato cultural. Tais produtos levam como marca de produção a imagem do investidor a serviço da propaganda de seus serviços. Uma maneira eficiente de apropriação de manifestações culturais que de outra forma representariam um alto custo, se compradas já como produtos acabados pela industria cultural. Investir na produção destes produtos no seu início também garante, muitas vezes, direitos de reprodução e uma associação mais duradoura do produto à imagem, à marca do investidor. Há ainda a vantagem adicional de se aperfeiçoar em grande medida a manutenção do consumo da marca: estes institutos podem trabalhar dentro de um certo recorte de mercado que tenha seu "gosto" mapeado pelas pesquisas de marketing. Uma elaboração fina do princípio de funcionamento da indústria cultural: apoderar-se do campo de possibilidades de lazer do consumidor e chamá-lo de cultura. E, por conseguinte, dar manutenção aos mecanismos de criação de gosto, através de um recorte estético e de interesse previamente planejado $^{4}$.

O Artenexo, artefato cultural criado pelo Workplace, não chega a se consolidar enquanto remanejador constante de recursos. Contava com investimento limitado e planejamento de curto prazo. À ambição por ganhos rápidos num curto espaço de tempo, faltou o saber especializado do marketing cultural. Daí a provável razão para a curta duração de suas atividades. 
Art. $3^{\circ}$ - Fica autorizada a criação, junto à Secretaria Municipal de Cultura, de uma Comissão, independente e autônoma, formada maioritariamente por representantes do setor cultural a serem enumerados pelo Decreto regulamentador da presente lei e por técnicos da administração municipal que ficará incumbida da averiguação e da avaliação dos projetos culturais apresentados.

Os mecanismos de formação para esta comissão podem ser encontrados em decreto regulador, artigo sétimo: Art. $7^{\circ}$. A CAAPC será composta por representantes do setor cultural e da Administração Municipal.

$\S 1^{\circ}$. Os representantes do setor cultural poderão ser indicados por entidades, instituições, sindicatos e associações civis, sem fins lucrativos e com objetivos e atividades predominantemente culturais, que se cadastrarem na Secretaria Municipal de Cultura, com sede ou seção no Município de São Paulo, existência e atuação efetiva e devidamente comprovadas, pelo prazo mínimo de 2 (dois) anos, e cuja diretoria tenha sido eleita em processo do qual participaram, no mínimo, 20 (vinte) associados.

$\S 2^{\circ}$. As condições de cadastramento e os documentos necessários à comprovação dos requisitos mencionados no $\S 1^{\circ}$ deste artigo serão indicados em portaria expedida pela Secretaria Municipal de Cultura, no prazo máximo de 60 (sessenta) dias.

$\S 3^{\circ}$. As instituições poderão indicar até 2 (dois) representantes para atuar em uma única área.

Art. $8^{\circ}$. A CAAPC será constituída por pessoas de compro- 
vada idoneidade e reconhecida experiência na área cultural, nomeadas pelo Secretário Municipal de Cultura, sendo, no mínimo, 6 (seis) titulares integrantes dos quadros técnicos da Administração Municipal e, no máximo, 7 (sete) titulares e 14 (quatorze) suplentes escolhidos dentre os indicados pelas entidades culturais cadastradas.

$\S 1^{\circ}$. O Secretário Municipal de Cultura escolherá, no mínimo, 1 (um) membro titular e 2 (dois) suplentes como representantes do setor cultural para cada área, dentre as indicações feitas pelas entidades credenciadas.

$1^{\mathrm{o}}$ - Os componentes da Comissão deverão ser pessoas de comprovada idoneidade e de reconhecida notoriedade na área cultural.

$2^{\circ}$ - Aos membros da Comissão, que deverão ter um mandato de 1 (um) ano, podendo ser reconduzidos, não será permitida a apresentação deprojetos durante o período de mandato, prevalecendo esta vedação até 2 (dois) anos após o término do mesmo.

$3^{\circ}$ - A Comissão terá por finalidade analisar exclusivamente o aspecto orçamentário do projeto, sendo-lhe vedado se manifestar sobre o mérito do mesmo. 
Dos jogadores

Neste ponto pós-fixado há um aparente ganho político no sentido de uma certa potencialização do debate acerca dos projetos analisados, através da participação de entidades culturais que tomem a iniciativa de inscrição. Mas ao voltarmos ao texto original, este ganho é posto em risco pela regulação de valores morais "universais".

O enunciado é revelador daquele ponto de vista oculto, ao qual não interessa admitir sua participação: Regulamentar a idoneidade de uma comissão é característico de um lugar de onipotência moral. Como dar "notoriedade" por si só como valor positivo?

Se, como lemos ao lado, a análise é orçamentária, então qual a finalidade da participação de agentes do campo cultural, e não fiscal, ou contábil? Se há um momento no processo de seleção de projetos em que o mérito deva ser discutido, este é o do debate na comissão de avaliação. 
$4^{\circ}$ - Terão prioridade os projetos apresentados que já contenham a intenção de contribuintes incentivadores de participarem do mesmo. 
Somos lembrados então que a discussão dos projetos na comissão não é definitiva para a concretização dos mesmos. Não se trata apenas de uma prioridade para um projeto que se demonstre adiantado no processo. A comissão, utilizando os critérios e intenções para os projetos culturais analisados anteriormente pode validar quase a totalidade dos projetos, já que os itens relativos aos valores são ao mesmo tempo vagos e abrangentes. Derivam de valores sociais amplamente aceitos, justamente por serem indefinidos. Aqui a cultura aparece como um vasto campo uniforme apesar da tentativa de representá-la como cheia de diversidade.

Somente considerando nosso item predileto, previamente citado, o "i” (a produção e difusão de bens culturais de valor universal, formadores e informadores de conhecimento, cultura, ciência e memória;), fica claro como praticamente qualquer atividade humana pode estar inclusa nestes critérios. $\mathrm{O}$ fato é que os projetos dependem de que se convença o investidor. É em torno deste outro personagem que giram as possibilidades de ação cultural. É ele que fará a escolha. Um pressuposto para um valor fundamental, manobrado pelo discurso sempre que necessário: a liberdade. No capitalismo recente, a experiência mais amplamente acessível é a do lugar do consumidor: escolher livremente entre os produtos oferecidos.

Do Gosto

Assim a lei estabelece o mecanismo que deve inserir a cultura no sistema de produção: através da seleção 
5: Para uma extensa fundamentação desta relação: TRACY, D. De. "Élements D’Ideologie". Paris, Libraire Philosophique J. Vrin, 1970;"Penser, comme vous voyer, cést toujours sentir, et ce nést rien que sentir”. 
direta realizada pelo financiador empresário. Ele escolherá na prática as ações culturais dirigidas ao público, através de recursos públicos por critérios privados, característicos de um grupo que tem valores e interesses restritos.

A avaliação dos projetos então tende a ser feita de acordo com dois critérios: o dos interesses comerciais evidentes no envolvimento ou parceria de determinada empresa com determinado produto cultural (portanto dependentes de uma análise mercadológica relativa a este produto e seu público-alvo) e o do gosto, ou seja o juízo estético do empreendedor cultural, formado pelos valores caros a este grupo em particular, mantidos e reproduzidos por sua condição de consumidor.

A ideologia forma o gosto, ao mesmo tempo em que é formada por ele ${ }^{5}$. A manifestação cultural na forma de produto é, neste sentido, uma espécie de mercadoria plena, produzida para determinado público alvo ao mesmo tempo em que produz as possibilidades de apreensão deste público. Um pacote de produtos, que alavanca o consumo de todos os outros. O critério de escolha do investidor se formará dentro da racionalidade do planejamento de marketing, a partir de um gosto predominante, formado pelos valores que de tão hegemônicos, encontram espelho no próprio investidor. O gosto comum é o ponto de relação, o lugar de troca de todos os indivíduos que se quiserem empreendedores. $\mathrm{O}$ mecanismo da lei viabiliza a reprodução deste gosto, por que dele depende a viabilidade dos projetos. Realiza-se plenamente, de modo regulamentado, a máxima ideológica que ironicamente passa a ilustrar a natureza privada das decisões na política cultural: "Gosto não se discute". 
Art. $2^{\circ}$ - São abrangidas por esta lei as seguintes áreas:

I - música e dança

II - teatro e circo

III - cinema, fotografia e vídeo

IV - literatura

V - artes plásticas, artes gráficas e filatelia

VI - folclore e artesanato

VII - acervo e patrimônio histórico e cultural, museus e centros culturais 
Do campo

A cultura passa a ser território vasto e rico a ser explorado, que traz consigo a possibilidade de domínio no campo da economia. É no artigo segundo da lei que estão enumeradas áreas ou campos de atuação, as categorias que organizam seu uso.

Acervo e patrimônio histórico e cultural, ou seja, a memória e registro de todas as anteriores. Aqui, as contradições causadas por uma delimitação tão arbitrária ficam mais visíveis. A memória como registro que conserva patrimônio, sem reformulação, desligada da produção dos fatos. A manutenção e formação de museus e centros culturais. Este seria o campo de referência para a formação do Espaço ArteNexo. A possibilidade de um espaço de produção simbólica, embutido em um edifício comercial. Este é o item que facilita o caráter de empreendimento que deve sustentar a todos os outros. Trata dos espaços de circulação de outros campos de produção cultural.

A divisão destas produções em categorias só pode facilitar em certa medida a organização e seleção dos projetos se a visão de quem seleciona for categorizante. Mais uma vez, a visão de um sujeito que se coloca como que de fora da cultura, tomando-a por conteúdo a ser organizado.

O termo "campo" aponta para o caráter geográfico destas concepções; há um predomínio do espaço como matéria, como alvo de uma ação no tempo presente. Um presente absoluto que dá vida a estes espaços por estarem pretensamente inertes, estanques, passíveis, como paisagens idealizadas. De fato, a definição mesma de paisagem se situa entre duas posições diferentes assumidas pelo su- 

jeito: uma, a de uma classificação de territórios. Outra, de uma ação de processos sobre estes territórios.

Tal procedimento classificatório, fundamento do museu e da geografia em suas fundações, baseia-se em um representar que exclui a si mesmo do quadro de visão. A cultura, que se define entre outras coisas por sua oposição ao que é natural, oferecendo representações da natureza como objeto de transformação, ironicamente ocupa agora o lugar de objeto, para um sujeito ainda mais oculto.

Do artista

Qual a expectativa do Estado em relação à Arte? A de funcionar para a manutenção e revitalização dos valores ideologicamente necessários à manutenção do próprio Estado. Nossa condição atual, no entanto, é a de uma relação de sujeição do Estado ao capital. Toda uma ideologia que valorava positivamente o Estado, representando-o como catalisador de conquistas e poderes, como unificador de vozes de uma grande população de iguais, aliado a abstrações como pátria ou nação, foi substituída por outra, que justifica a sujeição do poder público a interesses privados através de independência, autonomia e eficiência. $\mathrm{O}$ artista, em ambas as situações, é chamado a reforçar valores manobrados pela ideologia, quando não seduzido pela função de abrir caminho para certas investidas do capital. "Chamado" é o termo que escolhi propositalmente para que ainda possa acreditar na possibilidade de uma postura do artista, dimensionada pela potência de seu trabalho, que resista critica- 
6: "De um lado os artistas fazem de tudo, por que tudo lhes é indiferente, de outro lado, se especializam ao infinito". Proudhon, Contradictions Économiques. Citado em BOURDIEU, P. "A economia das trocas simbólicas”. São Paulo: Perspectiva, 2005 
mente a estas demandas. Para tanto é preciso que se questione a convicção de que a arte se constitui como esfera, para além de autônoma, independente da ordem social, o que possibilita uma atuação alienada do sujeito artista. Digo sujeito por ser também este um lugar a se ocupar. Um lugar privilegiado de criação e independência, onde a liberdade se manifestaria a cada ato de expressão. Este lugar é invocado para todos os participantes do campo da ação cultural. Sentir-se artista justifica a ignorância em relação à economia das chamadas políticas culturais. Uma ignorância necessária ${ }^{6}$.

Ritmo e fragmento

Este caráter de provisoriedade e imediatismo que se vê na lei, parece estar ligado à desistência do Estado de sua função mediadora entre setores da produção em âmbito geral. Ele em parte se abstém. Resta uma outra concepção de regular que não inclui mediação, apenas uma redução de atrito entre as partes...

A lei impõe-se pela flexibilização da própria lógica de estruturas anteriores em função da demanda imediata de um capital em movimento contínuo. Não se trata de um imperativo pela manutenção da ordem, mas pela imposição de um ritmo, que serve à manutenção de um estado de coisas sempre precário, e assim, da própria precariedade como condição perene.

É o ritmo o elemento estruturante a composição 

deste texto. Um ritmo afobado e claudicante, marcado por freqüente descompasso. O progresso concatenado, antes valor aferido pelas leis, dá lugar ao descompasso que faz tudo funcionar de modo mais fluido. É a batida fora do tempo, o fôlego irregular, a falta de constância que produz o movimento sem ruído.

Meu relato de leitor aqui parte da fragmentação como experiência. Minha reação a esta fragmentação foi o esforço em recriar nexos, e pela forma mais acessível para mim, reescrevê-la, organizá-la, conferindo ao punhado de itens que pendiam soltos uma ordem linear que pudesse apontar para suas contradições.

Por algum tempo me perguntei se expor os artigos na seqüência em que se apresentavam não seria, de certo modo, reproduzir a forma conflitante e contraditória do texto da lei. Parte da dissertação acabaria por servir de suporte narrativo a este texto, tornando-o legível e desse modo, ratificando seu conteúdo, ao invés de criticá-lo. Afinal, dar corpo a algo tão fragmentário não seria como aderir ao mesmo desejo de composição e harmonia capaz de impedir uma visão crítica de sua fragmentação?

Pensando no texto da dissertação e no texto da lei como formas de organização de pensamento, que se conectam a possibilidades de análise e de reflexão, talvez a dissertação tenha por limite a compreensão das reais dinâmicas econômicas justamente por demandar sentido. Escreveríamos então, sobre economia, irremediavelmente fadados a narrar o passado, embora presos a um presente imperativo. Só os gráficos que vivem estas transformações em tempo real estariam aptos a serem imagens do real, pelo que o real hoje é imagem. E a forma da escrita talvez já não possa descrever as imagens que habitamos.

De qualquer modo, é a forma mesma da dissertação, do 

texto, seu pensamento editivo e ordenador, que possibilitou minha apropriação do texto da lei. E o mesmo, me parece, acontece com a experiência produzida por Workplace/ Werkplaza. 



\section{Entorno}

Ao voltarmos a pensar o que poderia ser feito naquele espaço, é que alguns relevos começaram a emergir dos planos brancos que cobriam aquelas salas. $\mathrm{Na}$ verdade, era preciso querer ignorar as idiossincrasias que teimavam em aparecer para que se pudesse chamar aquele espaço de um "cubo branco", como nos fora descrito anteriormente o ArteNexo. Os tapumes que cobriam as janelas, as portas de vidro que se abriam simetricamente para os espaços contíguos, a única janela que cortava em ângulo as paredes falsas, a tubulação do ar condicionado. Tudo apontava para os vestígios de uma estrutura prévia que havia sido pensada para as situações de trabalho para as quais o prédio fora projetado, e que apesar do esforço para que se atenuasse, insistia em se pronunciar. Deste modo, o ArteNexo nem garantia a já tão questionada neutralidade de um espaço expositivo tipicamente museológico, como ditavam alguns dos princípios de nossa modernidade, tampouco investia na especificidade daquele lugar, que ainda mantinha indícios do quotidiano para o qual havia sido projetado. 

Funcionalismo

A função que exercíamos no quotidiano do Workplace era de difícil descrição para seus funcionários. Implicava numa longa e absorta observação de um conjunto vazio muito bem iluminado, seguida de nossa inexplicável ausência durante dias.

O estranhamento talvez viesse da relação distraída e ao mesmo tempo acostumada que os funcionários mantinham com a arquitetura do prédio assim como com o bairro, de forma geral. Para eles, o prédio era um contêiner de procedimentos habituais, como uma espécie de manual de instruções em tamanho real. Em seu caminho quotidiano de tarefas, era-lhes exigida um tipo de atenção descontínua que se ia prolongando pela duração dos turnos de trabalho. E os espaços do edifício existiam conforme se estruturava a missão do dia.

Por isso não posso dizer que Workplace fosse funcional, como se nele, vantagens funcionais pudessem ser explicadas pelo próprio uso, o que poderia implicar em situações de escolha ou decisão para seus usuários. Ao contrário, o espaço não parecia explicar, muito menos se estruturava a partir de qualquer argumento que pudesse justificar sua existência. Sua relação com o usuário era instrutiva, não construtiva. Um pouco como o modo como a Lei Mendonça colocava as novas regras do funcionamento da cultura: não em razão de uma funcionalidade que pode ser socializada como meio para fins coletivos, para o público, mas em função de uma racionalidade técnica apresentada como inevitável. 

Estruturas e discursos

Após cada um dos períodos em que nos ausentávamos, era de se perguntar se o prédio ainda estaria lá quando retornássemos, tal era a habilidade que exibia em criar a ilusão de sua própria imaterialidade. Ao nos afastarmos uns quarteirões, dava a impressão de se comportar como uma grande placa recortada, cujo contorno ia se alterando à medida em que tornávamos a nos aproximar.

Internamente, o prédio era de uma estrutura ausente, ou mesmo obliterada pelos elementos com que se relacionava. $\mathrm{O}$ andar pelos corredores internos não informava a posição dos conjuntos num todo arquitetônico. Pareciam elementos modulares amontoados em andares. Só do elevador panorâmico é que se abria uma visão cujo limite não era o caminho a ser seguido. Dali o prédio parecia se gabar de sua localização na cidade. Subindo ou descendo, o visitante podia estar absorto a olhar a paisagem de que tinha saído ou que teria de enfrentar novamente. Mas devia, para tanto, tomar o ponto que teria o edifício como se este fosse assim um mirante. Um mirante não oferece vista para si mesmo.

Não estou certo de que uma discussão hipotética que opusesse os princípios estéticos da arquitetura moderna à pós-moderna, em seus discursos, chegaria a servir para uma melhor compreensão de Workplace. Mesmo que admitamos que o pós-modernismo em si deva ser apontado como discurso, o Workplace e projetos vizinhos parecem menosprezar até os princípios básicos do discurso pósmoderno em seus enunciados arquitetônicos. Isto por que havia na geometria previsível de Workplace uma espécie de nostalgia em relação ao moderno, ou pelo menos do 

moderno como discurso da vanguarda, agora reprocessado como discurso do novo, como se isto fosse necessário para retomar, a seu favor, certo gosto arquitetônico até recentemente hegemônico em São Paulo (afinal a cidade teve sua identidade construída a partir da idéia de progresso, termo que foi base para o discurso do capital em sua configuração moderna). A configuração de Workplace é regida pela imagem tanto do "moderno" quanto do "contemporâneo", mas apenas no que estes termos puderem oferecer de estereotipado, no tanto em que ambos puderem ser aproveitados como valores reificados, desligados de quaisquer compromissos autênticos com a noção de espaço público, presente em qualquer um destes discursos.

Urbanismo operacional

A camuflagem depende do meio. Workplace não merece muito do mérito. As construções ao seu redor mimetizavam-se como cópias umas das outras. Não se tratava, que fique claro, de um grande aparato tecnológico, ou projeto de grande elaboração, mas de uma versão barata, de pequeno porte, materiais pouco nobres e proporções não muito acuradas, de um tipo de empreendimento superado tecnologicamente a todo tempo.

Estas construções têm a efemeridade como valor primeiro, por conta da pressão de se apresentarem sempre como a última palavra em projetos, sob risco de perderem investidores acostumados a alugar temporariamente espaços de trabalho, movendo-se continuamente para novos 
1: "Os imóveis [desta região] fazem parte das carteiras de investimentos dos fundos, juntamente com ações, depósitos a prazo, fundos de investimento e outros tipos de aplicação" em FIX, M. "Parceiros da exclusão". São Paulo: Boitempo, 2001 
edifícios que tenham se atualizado em termos de planejamento tecnológico.

A configuração da Rua Funchal (Vila Olímpia, São Paulo), constituída em sua maior parte por prédios comerciais, incluindo Workplace, advém de uma reformulação urbanística de iniciativa do poder público municipal, que originou a avenida chamada "Nova Faria Lima", possibilitando uma série de novos empreendimentos imobiliários na região. Uma das características deste tipo de empreendimento é o fato de comumente ser financiado, através de um sistema de cotas, por fundos de investimento, a maioria, fundos de pensão. Daí a ligação direta entre a especulação imobiliária e a financeira ${ }^{1}$.

Há regiões inteiras da cidade que foram preparadas pelo poder público para grandes empreendimentos. Por preparadas, entenda-se um conjunto de operações que pode se iniciar por alterações em leis de zoneamento, terminar em alterações da agenda de implementação de infraestrutura da cidade (a fim de tornar estas regiões úteis mais rapidamente), passando pelo desalojamento de populações faveladas, ou seja, a destruição dos barracos construídos pelos moradores nestas regiões, que antes permaneciam "esquecidas" pelo poder público. Aliás, é jogando com este suposto esquecimento, que se tornam possíveis à especulação ganhos elevados em um curto espaço de tempo: a partir da imprevisibilidade planejada do investimento público. Hoje uma região residencial, amanhã uma via expressa, hoje uma favela, amanhã uma região altamente valorizada pela construção de condomínios de alto padrão. A parte publicável deste conjunto de operações leva o nome de "Operação Urbana", na qual o poder público cria condições para a iniciativa privada. Este papel facilitador da administração é comum e extensivo ao lugar do Estado exposto 
2: Em uma das asserções de Harvey para este estilo administrativo, o empreendedorismo: “...a parceria público-privada é empreendedora pois, na execução e no projeto, é especulativa, e, portanto, sujeita a todos os obstáculos e riscos associados ao investimento especulativo, ao contrário do desenvolvimento racional e planejado." p 173, HARVEY, D. “A produção capitalista do espaço". São Paulo: Annablume, 2005 
na Lei Mendonça, inclusive pelo uso do mesmo termo: "empreendedorismo"2.

Esta condição de permanente efemeridade satisfaz plenamente os modos de operação especulativos predominantes nas atividades econômicas hoje; a especulação imobiliária e a financeira aparecem como diretamente ligadas à conformação do espaço urbanístico e arquitetônico do Workplace. Novamente nos deparamos com uma nova condição no que se refere aos vínculos entre economia e política. Como se coloca acima do capital produtivo, onde o retorno dos investimentos depende de conformações mais, digamos, estáveis, o capital fictício funda suas estratégias de ganho em sua própria volatilidade, num movimento contínuo em busca de negócios em alta, que paguem muito em pouco tempo. A condição para lucro é a efemeridade de sua atuação.

Apesar de fictício, suas implicações são bem concretas, já que são estes investimentos que conformam os espaços urbanos atualmente. O caráter transitório que marca a lei de incentivo em sua construção textual, que força o constante redesenho urbanístico da cidade, jogando com territórios e populações, e que é base de funcionamento para as operações especulativas no setor financeiro, se transfere para as formas de seus produtos em seus princípios estéticos. Workplace, enquanto construção, revela de maneira emblemática em suas formas este mesmo princípio do efêmero, pela condição de transitoriedade para qual foi planejado.

Daí o interior de Workplace ser um oco reversível, sempre em função de um uso variante, que aceita a fluidez das necessidades que gera e refaz seus espaços: a fluidez do próprio capital. Por isso sua casca contém, mas não informa. Objetiva apenas um aparecimento superficial. Funcio- 
3: Minhas observações encontraram referência em AUGÉ, M. "NãoLugares; Introdução a uma Antropologia da Supermodernidade". Campinas: Papirus, 1994. Escolho com certa dificuldade uma das várias passagens que podem reiterá-las: “..., um mundo assim prometido a individualidade solitária, à passagem, ao provisório e ao efêmero, propõe ao antropólogo, como aos outros, um objeto novo cujas dimensões inéditas convém calcular antes de se perguntar a que olhar ele está sujeito. Acrescentemos que existe evidentemente o não-lugar como lugar: ele nunca existe sob uma forma pura; lugares se recompõe nele; relações se constituem nele [...]."

4: Apontada em seu discurso por autores como O'Doherty (O’DOHERTY, B. "No Interior do Cubo Branco". São Paulo: Martins Fontes, 2002) e Crimp (CRIMP, DOUGLAS. "Sobre as Ruínas do Museu". São Paulo: Martins Fontes, 2005). 
na como um cenário, que se autonomiza ao ocupar repetidamente o primeiro plano, encobrindo o jogo de relações ininteligíveis, apesar de reais, promovidas pelo movimento do capital em sua mais nova versão. Workplace, apesar de ser espaço privado, fechado, acabava por se revelar como lugar de passagem ${ }^{3}$.

Adaptações

O espaço expositivo em que ocorreu a intervenção passou a se mostrar para mim como a superfície de todo este encadeamento de processos. Como uma casca que não chega a se solidificar por conta do movimento constantemente performatizado pelo material fluido que tenta cobrir. Na tentativa improvisada de se configurar um "cubo branco", a ideologia deste "espaço da Arte"4, funciona como referência, como que para recuperar um discurso, que embora já desgastado, ainda pode servir como imagem, como signo para a atividade artística ou cultural. A solidez, a neutralidade, a capacidade de produção de história, os valores ligados a este tipo de espaço que se pretende museológico, enquanto fatores ideológicos, eram encenados de forma a servirem a outro discurso, ligado ao efêmero, ao típico, à possibilidade de um aqui e agora liberador característico da adaptabilidade que rege o museu em sua configuração mais recente. No entanto, Artenexo não representava as últimas concepções de espaço cultural de seu tempo. Para que pudesse existir era necessário que referenciasse uma noção icônica de espaço da arte, para que se colasse nele a ima- 
5: Ver, como eu vejo aqui, uma relação formal entre dois momentos não implica em reconhecer uma relação causal imediata entre um dispositivo legal do funcionamento das políticas culturais e o que ocorre no sistema político instituído, ou na câmara dos vereadores, mais especificamente. Seria ingenuidade fantasiar com os senhores da câmara arquitetando um texto tão poderoso a ponto de colocar as forças econômicas mais diversas em movimento concatenado. Relacionar a lei com o entorno urbanístico de Workplace, pelos pontos de conexão presentes em seus discursos é situá-lo em meio às dinâmicas com as quais tanto a lei quanto o entorno urbanístico se relacionam, e desse modo, entender a especificidade de sua situação política. 
gem de espaço representante da produção cultural, inserido proporcionalmente no todo da cadeia produtiva do capital. Da posição em que estava, não podia repetir o movimento efetuado pelos museus em sua última reconfiguração. Enquanto estes se assemelham cada vez mais aos edifícios de negócios, lojas, ou em alguns casos até parques, o Arte nexo intentava camuflar-se de museu ou galeria, mas numa versão nostálgica, que talvez funcionasse como mensagem mais direta para o jogo burocrático da tributação.

Este espaço adaptado, então, é em parte metáfora e resultado dos processos sociais e econômicos esboçados aqui a partir do que se pode entrever em seus discursos. O edifício Workplace assume a forma das estruturas como estas se representam ${ }^{5}$ : em uma sociedade exclusiva, estruturada em função de uma racionalidade utilitária, forma-se um espaço a parte, onde o que for cultural pode ser visto, tocado e posto a funcionar em consonância com o todo. Assim esta iniciativa despretensiosa procurava dar significado ao lugar de trabalho. Um passo anterior ao da diluição entre trabalho e lazer, dado por projetos arquitetônicos posteriores.

Nomes como Workplace e ArteNexo podem se revelar de um realismo inusitado. Workplace, lugar de trabalho, do funcional, da eficiência, num inglês que tenta explorar o trabalho como valor positivado: a construção toda poderia ser resumida a trabalho, já que este é a unidade de medida última que o torna possível. Mas como em toda mercadoria, qualquer vestígio do trabalho real necessário para sua fatura ameaçaria sua condição de produto fetichizado. Do mesmo modo, trai a si próprio o nome do projeto; "Arte nexo". Parece nos dizer de uma arte que anexada, como um território, passa a trabalhar em prol do todo, ou, em se tratando de um organismo, assume a forma de apêndice. 

Arte, aqui, vista como apenas uma dentre outras manifestações culturais. Esta visão da cultura como parte autônoma de um sistema de produção é a mesma que encontramos no texto da lei aqui exposto. No entender da lei, como vimos, um item da mesma importância que a própria criação de espaços culturais como o ArteNexo. 



\section{Descrição}

Ao tentar elaborar um projeto para o programa de pós graduação da universidade, tive como referência uma estrutura de itens que se repetia em alguns dos projetos que li. Em "memorial descritivo", tentei elaborar uma descrição do que então me lembrava de Workplace/Werkplaza. Hoje sei que o que me lembro do trabalho depende mais deste pequeno relato do que as fotos que guardo da intervenção no espaço de Artenexo. Lia-se:

"Passo agora para uma breve descrição do resultado de nossa intervenção: uma estrutura composta de ripas de madeira que tomava todo o espaço das duas salas, exceto por um corredor de um metro de largura junto à parede. Esta estrutura de ripas era organizada por um padrão, uma espécie de célula de composição que se repetia e tinha continuidade em toda a extensão da estrutura; uma ripa vertical ligada a duas ripas diagonais em direções diferentes 

(estando assim todas as ripas ligadas, pregadas do mesmo modo sempre pelo mesmo número de pregos). À altura de dois metros pra cima foi estabelecido um limite; o espaço foi pintado com um tipo de branco diferente do expositivo, mais brilhante, no caso das paredes e teto. As partes das ripas que passavam desta altura foram pintadas com uma resina brilhante. De maneira que a sensação que se tinha era de que o 'brilho' havia tomado conta do espaço, vindo de cima, descendo até aquele limite um pouco acima das cabeças dos visitantes. Em uma das paredes, (a que havia sido construída tapando as janelas do edifício) este brilho continuava descendo apenas nos espaços em que se contrapunha ao desenho original das janelas, ou seja, formando placas e esquadrias de tinta brilhante nos lugares onde, se não houvessem sido cobertas, poderiam ser vistas as janelas do prédio. Estas "não janelas" brilhantes tinham como referência uma única janela que havia sido poupada e que também recebeu à mesma altura a cobertura de resina.

A iluminação foi alterada para que se mantivessem as sombras das ripas da estrutura e deixasse mais visível a diferença de tons entre as partes opacas e as brilhantes. Ao final, a estrutura propunha ao visitante que ele entrasse por uma porta de vidro e seguisse próximo à parede, contornando as ripas, como quem dá a volta ao redor de uma cerca. Este caminho, no entanto, deixava ver por entre as ripas toda a estrutura e os desenhos nas paredes. Enquanto se caminhava ao redor, o contraste entre o branco expositivo e a cobertura brilhante que descia do teto ia ficando mais visível. Como o percurso se dava próximo à parede, passava-se espremido entre os desenhos de janelas e a estrutura de madeira que, embora se assemelhasse a uma cerca ou jaula ou um destes suportes feitos em espaços fechados para reformas em tetos e coberturas, deixava à mostra seu 

funcionamento através de seus vãos (cada ripa guardava cerca de um metro e meio de sua vizinha mais próxima), além de sua precariedade enquanto divisória do espaço. $\mathrm{Na}$ verdade a estrutura não se validava nem como cerca, pelos espaços vazios, nem como suporte, por manter em todas ripas uma distância segura do teto, nem como estrutura em si por ser, apesar de visualmente limpa e geometricamente organizada, precária demais para suportar qualquer peso.

Ineficiente em tudo isso, também falhava em evitar a descida do teto deste espaço outro, que não reflete, do mesmo modo plano, a luz plana dos espaços expositivos. Pelo contrário, guardava uma relação mais passiva, de integração ou submissão a este plano descendente.

O final do percurso era simplesmente a outra porta de vidro que, simétrica à primeira, poderia também ter sido usada como porta de entrada e vice-versa. Entrar, andar e sair. E estava-se entregue novamente àquele corredor comercial que oferecia a opção entre outro conjunto e o elevador, e por este, subir ou descer."

Uma série de imagens que se alinham, justapondo-se, até que se fixa um caminho que o leitor só pode enxergar depois de por ele ter passado. Um relato em que eu pretendia ser razoavelmente objetivo, tentando guardar meus pré-juízos para depois, para com isso valorizar um trabalho de análise crítica que o projeto de mestrado oferecia como objetivo principal. Na verdade, uma pequena narrativa quase sem tensão, que já mostrava, na mesma medida em que tentava esconder, o caminho que me faria seguir em direção àquilo que eu já planejava concluir a respeito de Workplace/ 

Werkplaza. Minha pretensa objetividade em relação ao que me dizia a memória esquecia de que, ao descrever, eu já delimitava o caminho do expectador pelo trabalho, colado que está na verdade ao caminho do leitor. Fora já o relato que criara este caminho a pretexto de descrição e não mais a intervenção, cuja possibilidade de experiência já era indisponível.

Estabelece-se assim uma bifurcação inevitável. Um caminho construído pela descrição da intervenção, dado pela possibilidade de leitura, e outro que a intervenção constitui e, reciprocamente, por ele é constituída. O primeiro é lugar construído pelo campo ou meio onde a análise critica do trabalho se propõe a ocorrer, ou seja, a dissertação de mestrado enquanto possibilidade de pensar e realizar; inevitavelmente, um desdobramento discursivo da intervenção. O segundo é lugar tornado possível, agora, pelo primeiro.

Este desdobramento discursivo da ação inicial que é a dissertação acaba me indicando o entendimento do próprio texto como lugar, sem, no entanto, que se oponha a este entendimento uma tentativa de compreensão mais aprofundada da relação que a intervenção conseguiu estabelecer com o espaço de ArteNexo. 
1: Em "A idéia de circulação na obra de Cildo Meireles", Dissertação de Mestrado de Thaís de Souza Rivitti, São Paulo, fevereiro de 2007.

2: “A explicação parece simples: assistimos, no começo, à descrição de um estado; ora, a narrativa não se contenta com isso, exige o desenvolvimento de uma ação, isto é, a mudança, a diferença." Em Todorov, T. “Os gêneros do discurso". São Paulo. Martin Fontes, 1980. 


\section{5. (Ficção)}

A combinação destas duas tarefas me remete a parte da produção de Cildo Meireles, com a qual proponho uma rápida aproximação.

Duas questões me atraem nesta produção, características que parecem presentes em toda sua trajetória, podendo servir de referência para a análise de Workplace/ Werkplaza. A primeira seria a relação de tensão que seus trabalhos estabelecem com os espaços em que se inserem. A segunda seria a colaboração que se estabelece entre algumas de suas intervenções e seus relatos. O próprio Cildo, em entrevista, afirma que várias de suas obras se fundam na oralidade ${ }^{1}$. Esta consciência sobre a condição de dependência em relação à memória, e sua reelaboração através do relato, pode servir como referência importante para a compreensão do texto da dissertação acadêmica como lugar de desdobramento do objeto analisado.

Relatos de algumas das intervenções realizadas por Cildo ainda circulam como novas possibilidades de experiência. Embora nasçam de descrições, pelo caráter subversivo das intervenções, passam a constituir narrativas ${ }^{2}$, que por sua vez constituem novos desdobramentos das intervenções iniciais.

Escrevo esta aproximação como um parêntesis (que pode conter relações entre Workplace/Werkplaza e situações que se colocam como paradigma para qualquer intervenção), de modo que este relato se dê num movimento contínuo entre minhas percepções, resultantes do contato com os trabalhos, e a elaboração de certos aspectos de seus contextos discursivos. 


\section{Inserções em circuitos}

ideológicos, projeto cédula (1970) Carimbo de borracha sobre cédulas, dimensões variáveis.

3: Devo a Carlos Arouca o relato aqui reproduzido (e um tanto reformulado), pelo qual agradeço. 
Inserções

Não consigo elaborar a experiência com "Inserções em Circuitos Ideológicos" fora da forma narrativa. É pelo relato que subsistem ainda hoje alguns dos que considero os melhores trabalhos de Cildo Meireles, e apesar de funcionarem em diálogo com alguns dos objetos alterados expostos em montagens demonstrativas, a potência conferida a estes trabalhos pela narrativa independe das cédulas ou garrafas de coca que restam nas vitrines dos museus. O recontar de experiências vividas ainda circula. Por exemplo: a lembrança infantil narrada por um amigo ${ }^{3}$, de, na pressa em comprar qualquer coisa, conferir o valor da cédula e perceber uma inscrição não familiar, fora de lugar, mas ainda lá. Perguntar ao pai "quem é Herzog" é já saber que este alguém morreu, foi morto. É reconhecer imediatamente no rosto do pai a expressão que sinaliza a transposição de um limite, que reprova a tentativa (involuntária?) de forçar entrada no distante mundo dos adultos. E que eficientemente faz calar a pergunta seguinte, que deve ressoar por tempos ainda: Quem?

Assim a culpa está posta. Neste caso em relação ao pai, mas em tantos outros casos, em relação ao pai de todos: O Estado da ditadura. Em todo caso, somos perguntados como a sujeitos livres, uma pergunta que só quem se considera livre pode se fazer. $\mathrm{O}$ espaço público está instaurado novamente, ali, no caixa da padaria, naquele momento ou situação, até que recebamos as respostas de sempre, ou antes, até aceitarmos as respostas de sempre. É neste tipo de memória pessoal em que se dá a base de desdobramento do trabalho, garantindo uma relação de mútua constituição entre obra e sujeito. 
4: "Quando a ideologia religiosa se põe a funcionar diretamente interpelando a criancinha Louis como sujeito, o neném Louis é já-sujeito, ainda não sujeito religioso, mas sujeito-familiar. Quando a ideologia jurídica [...] se põe a interpelar como sujeito o jovem Louis falandolhe não mais de Papai-Mamãe, nem do Bom Deus e do Menino Jesus, mas da Justiça, ele era já um sujeito, familiar, religioso, escolar, etc.[...] Quando, enfim, mais tarde, em decorrência de circunstâncias auto-heterobiográficas, do tipo Front Populaire, Guerra da Espanha, Hitler, Derrota de 1940, cativeiro, encontro com um comunista, etc., a ideologia política (em suas formas comparadas) se põe a interpelar como sujeito o Louis que se tornou adulto, faz tempo que ele era já, sempre-já um sujeito, familiar, religioso, moral, escolar, jurídico... e ei-lo como sujeito político! Que, no retorno do cativeiro, passa do militantismo católico tradicional para o militantismo católico de vanguarda: semi-herético, depois lê Marx, se inscreve no partido comunista, etc. Assim se passa a vida. As ideologias não cessam de interpelar os sujeitos como sujeitos, 'recrutar' sempre-já sujeitos. Seu jogo sobrepõe-se, entrecruza-se, contradiz-se sobre o mesmo sujeito, sobre o mesmo indivíduo semprejá (várias vezes) um sujeito. Cabe a ele se virar..." Em ALTHUSSER, LOUIS. "Sobre a reprodução". Petrópolis, RJ: Vozes, 1999 
Curioso que uma das mais controversas definições de ideologia também dependa, para sua formalização mais plena, de um momento constituído pela narrativa. Althusser a inicia privilegiando a descrição de estruturas abstratas, que representariam nossas relações sociais, econômicas e políticas, mas acaba fazendo seu raciocínio desembocar em uma espécie de crônica do sujeito: o pequeno Louis é chamado aos seus deveres, à paga de suas dívidas de origem, a se constituir como célula de submissão em uma estrutura já dada, a encontrar seu lugar em vastas ficções que, interpostas, formam o plano ideológico ${ }^{4}$.

Ao mesmo tempo, imaginar estas estruturas é necessariamente abstrair, condição de pensamento de que Cildo se apropria em vários trabalhos da série de Inserções. É necessário imaginar um sistema (torná-lo imagem) para que seja possível a inserção de uma pequena diferença, a inversão de um signo, a realocação de um dado, para que se altere a narrativa mais particular, para que o ato de se comprar umas balas na padaria se revele para além da aparência mais normativa.

Cito Althusser, não para defender uma ciência marxista pretensamente não ideológica, mas porque me interessa como sua forma-teoria acaba por mimetizar formas de discurso ao mesmo tempo em que as descreve.

O narrar da formação do pequeno Louis talvez diga sobre o ser ideológico com propriedade justamente pela forma como narrativa, ideologia, e discurso se relacionam. Assim sujeito e objeto vão sendo constituídos um pelo outro, e o texto de Althusser parece indicar isso, a despeito de si mesmo. 


\section{Zero Cruzeiro}

(1974-78)

Litogravura

offset sobre papel,

$6,5 \times 15,5 \mathrm{~cm}$.

5: CHAUÍ, M. de S. "Cultura e Democracia: o discurso competente e outras falas". São Paulo: Ed. Moderna, 1981. Devo a indicação de que este texto conversaria com "Inserções..." a Marlito de Souza Lima, a quem agradeço. 
Cruzeiro

Ao invés de um discurso pretensiosamente não ideológico, um discurso crítico, que no interior do discurso ideológico, possa operar o desdobramento de todas suas contradições. Um contra-discurso ${ }^{5}$. "Inserções em circuitos ideológicos" parece de fato se formar a partir dos interiores do discurso. A crítica trabalha a partir da análise de um meio, que é tomado quase como matéria-prima para a intervenção. Com alguns poucos signos invertidos ou realocados, a operação consegue uma desnaturalização poderosa, e ainda conservar o discurso em sua aparência inicial, apenas para que esta saliente suas próprias contradições. Não é uma cédula falsa que poderia sustentar a pergunta anônima sobre o assassinato de um jornalista; devem ser todas cédulas "verdadeiras", para que se contraponha a representação "política" que serve de lastro para operações financeiras à nova possibilidade de atuação política inaugurada pelo ato de carimbar estas cédulas uma a uma. A questão circula no mesmo meio que os valores representados pela cédula e desse modo estes mesmos valores são questionados.

Em "Zero Cruzeiro", esta inversão se dá, dentre outros elementos, pela figura de um índio que toma o lugar da figura, tradicional em cédulas, de um representante político, personagem de uma ficção sobre o passado funcionando para validar o poder que, sendo presente, se quer eterno. Assim, a representação do índio em "Zero Cruzeiro" ganha novo sentido, que só é possível a partir de uma imagem construída a partir da representação de um espaço econômico. Retirada de um fluxo alienado de imagens que se realiza por meio da imprensa, a imagem inócua do índio, antes 

aplainada, volta-se para o espectador como uma Olímpia tísica e irônica.

Toda a série de "Inserções..." desmonta a idéia de um mundo dividido por áreas disciplinadas e estanques. $\mathrm{O}$ fato de termos em vários trabalhos da série o papel moeda como suporte formal para as intervenções, sempre retoma e aponta para a contradição gritante entre uma representação da identidade nacional e a esquizofrenia que marca as relações entre homem e capital. As dicotomias alienantes já cristalizadas: forma e conteúdo, economia e política, arte e vida, passam se revelar conectadas e tensionadas.

A representação de um Estado homogêneo é flagrada pelas figuras realocadas de representantes daqueles que não se inserem na lógica de produção e consumo que valida o acesso à vida política. $\mathrm{O}$ índio e o louco são não-cidadãos, por não serem capazes de assimilar a ordem e o progresso como valores fundados em uma racionalidade civilizatória, como objetivo coletivo.

Trata-se, portanto, de uma intervenção no que aparece como o estado natural das coisas, revelando o Estado naturalizado das coisas. E uma intervenção nisto que se revela como tipo de representação síntese, ícone autônomo do discurso ideológico; o dinheiro.

Ideologicamente, o dinheiro é a origem e o fim de todas as coisas. Socialmente, o proceder transacional proposto pelo dinheiro requer a abstração das coisas, relações e vivências humanas como competência básica de seu funcionamento. O que é representado passa a ocupar planos posteriores ao que representa. Representar é estar no lugar de algo, e o dinheiro passa a ocupar o lugar de qualquer coisa. Assim a questão da representação assume aqui um duplo viés: o da ideologia como representação e o do dinheiro como meio de representação. 


\section{Olvido}

(1987-89)

Tenda de células, ossos, velas e trilha sonora, alt. $400 \mathrm{~cm}$, diam. $800 \mathrm{~cm}$. 


\section{Esquecimento}

Contraposto a este relato, que reativa as operações presentes em "Inserções...", há outro, em primeira pessoa, que se origina de uma experiência ocorrida em visita à Bienal de São Paulo, edição de 1989. Lembro-me de me encontrar em uma sala escura onde o que identifiquei como o trabalho era mostrado por uma iluminação especial, que o amarelava, ou antes, realçava seu tom amarelado. Antes de se entrar já se podia ouvir um ruído que tomava o espaço; uma serra elétrica em ação. Impossível não associá-la ao corte de árvores. Ao centro da sala uma tenda de cédulas de países americanos no centro de uma espécie de piscina de ossos amparados por uma mureta de velas.

$\mathrm{O}$ percurso que fiz dentro do prédio por vários outros trabalhos me reaparece fragmentado e ao mesmo tempo repetido, como um filme primitivo. Quantos trabalhos vi naquele dia? Parece que a própria forma de edição fotomecânica já é constitutiva das lembranças que tenho ou produzo do trabalho. Uma colagem onde fotos e textos agregados posteriormente ao todo ocupam o mesmo plano hierárquico em que vive a experiência direta com "Olvido" (1989).

Apesar de, a começar pelo título, esta já se propor a falar de um esquecimento histórico, não percebo neste caso uma potencialização da obra causada pela reativação de uma memória especial. Ao contrário, me parece que este esquecimento histórico não passa por um sujeito consciente, apesar das reflexões propostas. Há um lapso entre a experiência possibilitada pela instalação e uma espécie de dever sentir, que de tão idealizadamente coletivo, se tor- 

na inacessível. Suspeito que esta sensação se deva a uma postulação de valor, a uma relação pouco desmistificante, pouco reveladora entre as questões históricas lançadas pelo trabalho e um suposto espectador. É como se esperasse uma reação culposamente aquiescente à recuperação de um tema que foi estrategicamente esquecido, para logo depois deste enfrentamento com a obra, todos pudéssemos esquecê-lo novamente, só que desta vez de modo talvez mais reconfortante, por termos concedido a isto uma lembrança socialmente concordante, como num memorial. Depois se volta rapidamente para um espaço de vivência cultural concentrada, como quer ser o de qualquer edição da Bienal, e o tema se dilui entre tantas outras coisas a serem experimentadas ou experienciadas (a depender da potência de cada trabalho em separado).

Não me parece que o sujeito que se constitui a partir desta experiência se veja obrigado a confrontar-se com as perguntas feitas em "Inserções...", e que seriam imperativas também neste trabalho: Quem são as vítimas, e principalmente, quem são os assassinos. Ao contrário, em "Inserções..." a estratégia da denúncia está ligada à razão sobre si. Está fundada no apontar para si, para a consciência do terreno ideológico.

O lugar que toma a instalação no prédio da Bienal parece pressupor ou desejar a autonomia do trabalho ao espaço arquitetônico e, portanto, à lógica institucional inerente ao evento cultural. A experiência possível é a do contato com um espaço à parte de todo o resto, como um suposto espaço da representação em si. O cheiro das velas, a luz amarelada que trabalha para a sensação de esmaecimento, o ruído calculadamente perturbador, tudo faz parte de uma estratégia de encenação. As qualidades cenográficas do trabalho são seus elementos construtivos mais importantes. 

Os elementos justapostos; ossos, cédulas, velas, assumem seu caráter de alegoria, falam mais para além de si mesmos do que sobre sua própria condição. Há um drama sendo encenado que, por mais que tenha algum peso, guarda de forma segura a possibilidade de que o assistamos de fora, de entrar e sair à vontade do espaço de encenação. O espectador pode simplesmente permanecer expectador...

Assim, embora o drama aponte para uma culpa que deveria nos obrigar a rever valores morais, a forma cenográfica do trabalho o mantém separado das razões políticas e econômicas que agem no real. E a própria idéia de que algo pode ocorrer a despeito de um real circundante é fundamentalmente ideológica.

Não que a tentativa de interlocução explícita entre trabalho de arte e arquitetura como dado deva ser louvada em qualquer caso, a qualquer preço. Há exemplos nesta mesma edição da bienal de apropriações da arquitetura que chegam a ser caricatas por seu oportunismo. Contudo, esta aparente oposição entre cenário e intervenção está no centro das possibilidades da forma quando se trata do prédio da Bienal.

Na edição da Bienal em que "Olvido" é exposto, em 1989, a idéia de uma "arte brasileira" já está bem consolidada, por possibilitar a exploração de um nicho mercadológico criado a partir da demanda internacional por visões de alteridade. "Olvido", a meu ver, não se contrapõe a esta situação de forma contundente...

A pessoalidade destas memórias talvez dê uma pista de como estes trabalhos propõem, de modos muito diferentes, a constituição dos sujeitos a partir destas experiências.

"Inserções..." e "Olvido" utilizam dois procederes, duas estratégias diferentes, recorrentes no modo de atuação de Cildo. Uma é a tomada de posição, que a partir de uma 

visão analítica, identifica no real algum sistema de qualquer ordem, reconhece-o enquanto condição de existência do real, e a partir disto pensa uma intervenção precisa, pontual, quase mínima neste sistema, encarando-o como o espaço ou a matéria-prima espacial do trabalho. Outra é a montagem de instalações que se estruturam a partir de elementos cenográficos, espaços carregados simbolicamente, que convidam o espectador a se empenhar em uma narrativa contida pelo trabalho, carregada de metáforas. Um espaço que poderíamos chamar de alegórico.

Tais modos de agir aparecem às vezes bem próximos entre si, ou funcionando alternadamente, às vezes em trabalhos diferentes, às vezes até no mesmo trabalho. Portanto não é o caso de separar os trabalhos em dois grandes grupos, mas sim de tentar entender dialeticamente estes procedimentos.

Mimese

Uma hipótese que podemos explorar é a de que entre as novas formas do capital e estas formalizações de Cildo há uma relação que, sem ser determinante, existe enquanto procedimento mimético inicial em seu trabalho. Ou seja, num primeiro momento de criação, as "Inserções..." assimilam algo da forma disto a que costumávamos chamar de sistema. Este sistema incorpora ideologicamente em seu modo de agir uma negação da representação como a conhecíamos. E introduzir uma cunha conceitual neste sistema, como é feito em "Inserções...", demanda uma visão de 
Razão/Loucura

(1976) Bamboo, correntes

de metal, cadeado e chave

$80 \times 150 \mathrm{~cm}$. 
sistema que só acontece por abstração, ou seja, no campo da representação.

$\mathrm{O}$ argumento muito utilizado para Duchamp de que a representação tem fim na "Fonte" foi várias vezes aplicado ao trabalho de Cildo Meireles. Vê-se a coisa (o dado, a chave, a cédula), logo não está a representação da coisa (uma foto, uma tela, um desenho). Contudo, estas coisas que Cildo em primeiro momento apresenta são muitas vezes já partes de sistemas, de uma relação entre coisas ou elementos participativos de um sistema, ou metáforas para sistemas inteiros. Uma distância intransponível entre chave e chaveiro ("Razão- Loucura", 1973), dada pela curta corrente, aponta para a relação de interdependência entre problema e solução, e pode ser metáfora para condições sócio-materiais tanto quanto ou paralelamente para limites do pensamento. Importa se a chave e o chaveiro falam de uma impossibilidade de concatenação mental, moral, internalizada. Mas também não deixam de falar de lapsos resultantes desta impossibilidade de concatenação, visíveis em nossa vida coletiva.

Uma nota de cruzeiro, na árvore de dinheiro, por exemplo, já é parte mesmo do sistema, por se colocar no circuito mercadológico da arte, ao mesmo tempo em que serve de visualidade metafórica para este, traindo-o em certa medida, já que o circuito desenvolve estratégias de opacidade de representação para que se mantenha o apelo consumista que esquenta as relações mercantis.

O mesmo parece ocorrer em vários trabalhos realizados por ele na década de 1970, a começar por toda série de inserções (nas cédulas, nas garrafas de coca-cola). Mesmo quando o trabalho se apresenta como objeto, que um primeiro olhar pode confundir como uma forma adaptada ao espaço expositivo, este acaba se revelando uma peça 


\section{Malhas da liberdade}

(1976) Quadro feito de estruturas modulares de ferro, $120 \times 120 \mathrm{~cm}$, atravessado por placa de vidro, $40 \times 100 \mathrm{~cm}$.

Mutações geográficas: Fronteira Rio/São Paulo (1969/70) Mala de couro, $60 \times 60 \times 60 \mathrm{~cm}$, com repartição interna para materiais (terra e plantas) retirados de cada um dos lados da fronteira a que o título se refere.

Arte Física: 30 km de linha estendidos (1969) Caixa de madeira, 60x40x8cm, contendo $30 \mathrm{~km}$ de linha e um mapa cujo detalhe prioriza a fronteira Rio/ Sao Paulo.

\section{Cruzeiro do sul} (1969-70) Cubo de madeira; metade pinho, metade carvalho. 9x9x9mm. 
solta que aponta para sua função de origem, e assim, aponta também para o discurso para o qual deixou de funcionar. É assim com "Malhas da liberdade" (1976), onde o próprio título é montado, como o objeto, revelando contradições. É assim também com "Arte física/Cordões: $30 \mathrm{~km}$ de Linha Estendidos" (1969) e "Mutações geográficas: Fronteira Rio/São Paulo" (1969/70), trabalhos onde a geografia assume o primeiro plano temático. E em "Cruzeiro do Sul" (1969/70) essa estratégia talvez seja levada ao extremo, até em termos físicos. A menção ao mapa é direta e assim é a própria representação geográfica que volta se revelar como, histórica, econômica e política.

Mapas

É insuficiente, para a produção de um contra-discurso, que se realize uma representação de um circuito ou sistema através de uma parte de seu funcionamento. É necessário que possamos representar a nós mesmos enquanto sujeitos na relação que mantemos com estes circuitos, sistemas ou discursos. Além de nos situarmos, é preciso que tenhamos consciência também de nossa incapacidade de representação total e unívoca. Todo mapa tem um caráter de precariedade e transitoriedade.

Não é o caso de exigir-se de uma obra de arte que exerça a função de um mapa, mas não deixa de ser perigoso esquecer as conexões históricas entre os dois. A modernidade investiu muito em representações que, a pretexto de 
6: HARVEY, DAVID. "Condição Pós-Moderna". São Paulo: Loyola, 2006 
possibilitar que se conhecesse o mundo, acabaram obliterando a capacidade deste modo de representar, unívoco e onisciente, de transformação do próprio mundo. Os mapas, a partir do renascimento, trazem na sua forma a relação intrincada entre representação e produção; o espaço só pode ser conquistado por meio de sua produção, que por sua vez se estrutura a partir da representação a partir do plano, do ponto de vista único da perspectiva, um esquadrinhamento do mundo que então passa a se mostrar como globo ${ }^{6}$.

Acredito que neste sentido, estes trabalhos que citei acima, especialmente "Cruzeiro do Sul", funcionem como uma espécie de contra-mapas, já que há uma tomada de posição em relação à representação que reconecta as esferas separadas pela cartografia tradicional e situa o sujeito a partir, não de uma visão apaziguante, mas de uma sucessão de reflexões.

Representação

Este tipo de procedimento maneja na direção de fazer a representação e a abstração jogarem a despeito de suas funções ideologizantes, em prol de desvelamentos dos discursos que as capturaram.

Há, no entanto, um processo de mutação destes discursos por conta de uma transformação das formas de atuação do capital. Se o dinheiro em si já capacita para um modo específico de abstração, o sistema financeiro proporcionará o desdobramento desta competência de pensamento na mesma medida em que esta the proporcione ganho. Se 
7: Claro que podemos encontrar as origens históricas deste processo alguns séculos antes e uma análise detalhada das andanças do capital exigiria um trabalho à parte. Por isso acho suficiente para este argumento um recorte rápido que retome estas transformações do início da década de 1970 por podermos localizar aí não apenas mudanças drásticas na esfera econômica, mas, necessariamente, a formalização de um discurso que procurava, a partir daquele momento, validar e fazer fluir estas mudanças como representações possíveis, disponíveis na mídia, com grande potencial de adesão de vários setores e classes no mundo todo. "Globalização" é a palavra-chave neste novo discurso. 
antes o dinheiro tomava a forma de qualquer coisa, a partir do início da década de 1970, se desencadeará um processo em que este se tornará auto-referente enquanto signo. As coisas que antes ocupavam segundo ou terceiro planos, agora somem de vista definitivamente. O capital se autonomiza?

Trocar retratos de políticos estampados em cédula por outras figuras menos familiares, a operação presente em "Inserções...", já não daria conta, a partir deste momento, da elaboração de um contra-discurso. O capital já não precisa da mesma validação simbólica do Estado, embora mais do que nunca o utilize como testa de ferro para seus negócios agora literalmente indescritíveis. Os índios e os loucos, que figuraram as notas alteradas em Inserções, e que antes cometiam o pecado de não trabalharem, agora estarão perdoados se simplesmente assumirem o novo lugar que lhes é oferecido, como ao resto da população; o de consumidores.

A crise de representação que decorre deste processo não se limita, obviamente, ao mercado financeiro. Este, como nova referência para as atividades do capital, passa a produzir competências que se alastram socialmente sob o título de nova ordem instituída e sua expressão se dá principalmente pela aceleração do ritmo de todo o fluxo das mercadorias (a começar pelo próprio dinheiro) no limite das possibilidades das novas tecnologias.

Em todo o discurso da propaganda e mídia expressa pelo processo globalizatório ocorre a positivação do efêmero como novo valor conciliatório da vida contemporânea. Isto porque o capital passa tomar a própria efemeridade como principal estratégia de atuação.

A partir desta raiz, temos dois desencadeamentos que podem ser colocados como vertentes deste processo, 
8: Tomo emprestada a interpretação do verbo por Flusser em: FLUSSER, VILEM. "Filosofia da Caixa Preta; ensaios para uma futura filosofia da fotografia". Rio de Janeiro: Relume Dumará, 2002 
e que eu gostaria explorar um pouco mais, por achar que podem ser esclarecedores para esta análise: A ascensão da Imagem à condição de mercadoria, e a hegemonia, no jogo capitalista, daquilo que Marx já havia definido como "Capital Fictício".

Imagem e ficção

Sem a pretensão de expor aqui um panorama abrangente da discussão acerca da primazia da imagem e suas implicações para uma representação coletiva de mundo em seus desdobramentos filosóficos, gostaria de propor um recorte que direcione a questão para as competências desenvolvidas pela forma imagem. Como ela se estrutura a partir de um todo realizável, no sentido de que dificilmente se mostra como algo a ser quebrado em partes e nunca como parte de um outro todo, um fluxo contínuo de presentificações acessíveis a todos: tornar imagem tornou-se realizar vivências que almejam este presente contínuo de um real onde tudo é posto como efêmero.

De fato imaginar tornou-se realizar. Um pouco de paciência com a ambigüidade dos termos: realizar no sentido de ratificar, através da produção da imagem, a nova possibilidade de representação coletiva de mundo e assim (próximo ao sentido que o verbo guarda na língua inglesa) percebê-lo desta nova maneira ${ }^{8}$. Realizar imagens hoje significa fazer parte, embora a partir dos anos 1970, fazer parte já significasse no mínimo o consumo de imagens. 
9: O capital fictício “...é definido como capital que tem um valor monetário e existência como papel, mas que, num dado momento do tempo, não tem lastro em termos de atividade produtiva real... em HARVEY, D. "Los límites del Capitalismo y la Teoria Marxista", México: Fondo de Cultura Econômica, 1991

Um termo não utilizado por Marx, embora muito difundido, é "capital financeiro". Vários autores o utilizam como descritivo de uma unificação do capital produtivo e o capital bancário, quando este último exerce hegemonia sobre o primeiro. O termo é freqüentemente usado para descrever economicamente a globalização, caracterizada pela expansão e domínio de ganhos especulativos obtidos em operações financeiras. Capital fictício, no entanto, seria o conceito mais acurado, que nasce das relações entre capital industrial, comercial e de juros MARX, K. “O Capital”, São Paulo: Difel, 1980 
Parece-me que neste ponto há um cruzamento relevante entre as novas possibilidades de atividade econômica e a construção de um discurso ideológico. A realização de imagens requer a assimilação de uma parte da fatura do discurso através de uma estética que passou a dispensar grandes aprendizados técnicos, fornecendo uma boa formação para seu uso através de um consumo disciplinado de seus produtos. O consumo de imagens significa o desenvolvimento de uma competência para a abstração ligada ao sentido da visão. Toda imagem é a apresentação de uma parte como o todo. Contudo ela faz parte de um fluxo de fragmentos que já não é representável. O ser ideológico aqui corresponde à sensação de se contemplar um todo apaziguante, quando tal visão corresponde a um mergulho em um cada vez maior número de partes, num movimento sem possibilidade de volta.

Ao mesmo passo que a vida se apresenta como imagem, não há abstração disponível para que se dê a representação das novas movimentações performatizadas pelo capital. O termo cunhado por Marx já aponta para como a representação é constitutiva deste conceito: "capital fictício"9.

Como ler o uso do termo "ficção" neste caso? Próprio de uma ficção, este personagem (o capital) se estabelece narrativamente, ganhando vida no tempo. Um elemento que nasce no imaginário e se torna realizador, passando depois a condição hegemônica no real. Sem pretensão de produzir teoria econômica, devo fazer com que meu texto possa abraçar narrativas para que meu relato prossiga. Seu andamento me permite saltar a explicação detalhada sobre sua formação histórica. De qualquer forma, a um certo ponto, o que se pode verificar é que as atividades de empréstimo em que está fundado o setor bancário, ou seja, o capital a juros, 

que no capitalismo recente tem presença generalizada, age de certa forma como uma representação de todas as formas de capital que a precedem. A representação aqui se baseia em uma projeção no tempo. Qualquer negócio resulta em uma certa receita que pode ser mais ou menos previsível. A previsão desta receita num recorte de tempo, (um ano, por exemplo), dividida pela taxa de juros, resulta num capital "criado". Este capital deixa de ser uma mera projeção caso outra representação ocorra: se por um título de propriedade este puder ser transferido comercialmente. Este título de propriedade não chega a ser capital real, mas tem poder de interferência real na economia como um todo. Passa assim a ter movimento próprio. O mesmo acontece com títulos de dívida pública, por serem um direito de apropriação de parte da receita pública, proveniente de impostos ainda a serem cobrados. E o mesmo acontece com ações e letras de câmbio, por representarem o direito à parte da mais-valia a ser obtida através da atuação do capital sobre o trabalho. Todos estes títulos de dívida, ações, títulos de propriedade, convertem-se, num momento posterior, em mercadorias negociáveis por si mesmas, e sua cotação no mercado se autonomiza em relação ao capital real.

Esta rápida explicação narra, além da evolução a que se refere, um processo abrangente de transformação de nossa capacidade de representar. Um movimento que desenvolve novas competências quanto ao sentir e ao pensar. Um tipo de abstração necessária tanto para a compreensão do conceito quanto para a própria leitura da narrativa que o contém e define.

Este movimento me faz voltar a um dos aspectos que não cheguei a aprofundar em minhas observações de "Olvido". Parece-me que os elementos que se apresentam a pretexto de representação da história de massacres das 

populações indígenas americanas obliterada por discursos de dominação, acabam se mostrando como signos que, na dinâmica da instalação, ou seja, pelo modo com que se relacionam, não ocupam lugares fixos em relação aos significados. Ossos, moedas, tenda, serra, como numa igreja barroca, não remetem a um significado original. Antes, fazem parte de um movimento cíclico de uma sintaxe onde signos e significados trocam de lugares constantemente.

Exemplifico narrando uma outra evolução: A cruz é signo cujo significado é Jesus Cristo, que por sua vez pode, simultaneamente, ser significado para o Cordeiro (Agnus Dei), que, quando traduzido do latim para o grego, passa de imagem a conceito, já que o correspondente para a isto em grego é agné, ou seja, pureza. A palavra dá origem ao nome próprio Agnes e/ou Ignês, que reaparece como na figura de uma santa que segura nos braços um cordeiro, que aponta novamente para pureza, e assim para Cristo e começamos tudo de novo.

Evidente que meu exemplo não vem por acaso. "Olvido", até onde entendo, se apropria causticamente da tradição católica mais ligada à teatralidade barroca que foi estética hegemônica estreitamente ligada ao discurso de dominação européia em toda a América Latina. Mas o caráter alegórico de que se apropria "Olvido" pode também ser relacionado à atuação deste outro signo, que já procurei identificar como onipresente no contexto mais recente: o dinheiro.

O dinheiro como signo atuante sob a primazia do capital fictício já não encontra paradeiro certo, já não encontra significado para além de si mesmo. Como forma mercadoria ele já viaja ocupando tanto o lugar de signo como o de significado alternadamente, até simultaneamente. Não se trata mais de uma representação simples, 

um dizer A para significar B, como ocorre em uma metáfora. Trata-se de uma sucessão de signos e significados que não se referem a nada fora de sua própria dinâmica, e nem por isso produzem uma dinâmica limitada, pelo contrário, esta dinâmica acaba por englobar e se apropriar de tudo.

Um processo de alienação radical por definição não pode ser onisciente, mas parece ter guardado para si as outras duas qualidades divinas. Se Marx já havia definido o dinheiro como meio de onipotência, a própria globalização agora lhe concede onipresença.

Se nos é inacessível a capacidade de representar o jogo de forças aos quais estamos sujeitos e das quais somos sujeitos, isto se dá inclusive por uma ideologia não apenas da ordem do discurso como representação confortável do mundo, mas como disponibilizadora de fazeres instrutivos para sua reprodução. A fatura do discurso competente hegemônico foi delegada a partir da produção de imagens que antes eram só consumidas, através de uma relação de consumo, baseada em competências limitadas aos sentidos.

Contrapondo a nova situação à questão da capacidade de abstração discutida a partir de trabalhos realizados por Cildo no início dos anos setenta, se estabelece a dúvida sobre o quanto ainda nos é possível representarmos a nós mesmos como indivíduos atuantes em algum plano comum de atuação política. O sujeito histórico parece incapaz de se olhar como, se já não único (indivíduo), ao menos como que conectado às razões, aos motivos, ações e reações de sua própria história. Seria ainda possível a elaboração por este sujeito de mapas confiáveis para sua localização no jogo do capitalismo atual? 


\section{Volátil}

(1980/94)

Madeira, cinzas, vela e gás natural. 300x1500x400 cm.

\section{Missão/Missões \\ (1987) \\ 600.000 moedas, 800 hóstias, 2000 ossos, área $4 \mathrm{~m} \mathrm{~h} 236 \mathrm{~cm}$.}

\section{Desvio para o vermelho, (1967-84)}

Sala branca, objetos vermelhos incluindo carpete, mobília, aparelhos elétricos, enfeites, livros, plantas, comida, líquidos e pintura. 100x $50 \mathrm{~m}$.

10: Este risco já aparece como tema em "FiatLux" (1973/79), embora me pareça que neste, a visibilidade do risco não chegue a se desconectar do real por conta de seu apelo a elementos do quotidiano ligado a seu caráter de ação performática.

\section{La bruja}

(1979-81)

Vassoura com cabo e base de madeira e linhas de algodão.

Dimensões variáveis. Instalação, XVI Bienal de São Paulo. 
Durante a década de 1980, a maioria das realizações artísticas de Cildo passa a ter uma relação, digamos, mais fundante com os chamados espaços culturais. Um dos primeiros deste período, "La Bruja" (1979/81), trabalho que dialoga com o conjunto das obras da Bienal, ainda pode ser visto como uma intervenção em um discurso formado pela própria exposição, e como ela se dá naquele espaço arquitetônico específico. Contudo, a maioria dos trabalhos a partir deste ponto parece mais dependente de um espaço expositivo que ideologicamente já era, há tempos, chamado de neutro. Isto por, a meu ver, se estruturarem a partir de um movimento de auto-encerramento. Não que isto seja possível, aliás, a questão é justamente esta: fazer parecer possível. Parecem almejar a uma condição de autonomia, mesmo quando elementos utilizados apontem metaforicamente para alguns limites ou contradições do meio em que se inserem. "Volátil" (1980), por exemplo, que funciona como dramatização de um risco iminente ${ }^{10}$, e cujo título parece se referir a um estado mais amplo de tensões sociais, coloca-se um pouco como um espaço à parte. A explosão possível pode se dar ali, naquele meio, ou em qualquer lugar, metaforicamente? "Desvio para o vermelho" (1984), um trabalho portentoso, também se coloca como um ambiente encenado, montado. Assim como, muito próximo estruturalmente de "Olvido" (1987/89), "Missão/Missões" (1987).

Evidente que não desenvolvo tanto quanto poderia aqui, em função de uma maior clareza do argumento, algumas grandezas destes trabalhos. "Desvio para o vermelho", por exemplo, consegue descobrir muito do aspecto 

ideológico de um ambiente familiar, quotidiano, justamente por serem os objetos cobertos por uma única cor. Não é meu objetivo um juízo definitivo desses trabalhos, apenas o levantamento de algumas características que talvez passem a ser constitutivas e sintomáticas de uma nova condição.

Contudo, se estes trabalhos se inserem num meio como o cultural de forma mais confortável, pouco tensa, deve dizer bastante deles o processo pelo qual a cultura foi instrumentalizada para a otimização da circulação de mercadorias, que agora incluem produtos culturais. Se desde a década de 1960 Debord já apontava para a capacidade da cultura de validar e promover todas as outras mercadorias, os anos 1980 mostraram que esta capacidade pode ser administrada em favor de uma reformulação da idéia de história, de conhecimento e de memória. O que se mostrava necessário, se a tarefa adiante era a de substituir valores como durabilidade e confiabilidade nas tradições, por efemeridade e volatilidade. Era mesmo preciso que este representante icônico da cultura que é o museu se reorganizasse, agora como um espaço habilitado para reconfigurações imprevistas, reajustável a todo o momento para uma visão que trabalha a memória e o conhecimento pelo procedimento da colagem de fragmentos interessantes, de imagens consumíveis. Será que "Volátil" propunha um sujeito que despertasse para a volatilidade do próprio meio que lhe ajudava a se sustentar como trabalho? Parece-me que o trabalho não chama atenção para a contradição de uma volatilidade como valor positivado...

O museu sempre foi fundamental para discursos de poder por oferecer a manipulação do espaço e tempo históricos. Na década de 1980, contudo, está em andamento um processo que possibilitará aos museus oferecerem os veredictos históricos do presente. Sua função se alterou 

para a edição cultural de tudo o que pode representar um aqui e agora glorioso. É o espaço onde se encena o viver cosmopolita que valida uma relação permissiva com nossa condição, por vender visões pretensamente amplas de um determinado real. Este novo museu funciona como a fotografia; quanto mais se recua para melhor captar o todo, mais se fica preso a um novo fragmento. O museu em si é um cenário. E se os trabalhos passam a se constituir como cenários, talvez haja aí uma acomodação formal que lhes retire força.

Adicione-se ainda que o fenômeno de internacionalização da arte que neste momento é celebrizada como brasileira, depende radicalmente do espaço museológico como base de circulação para os trabalhos no mundo todo. Por isso o espaço do museu, além de cenário modulável, ganha em eficiência quando os valores de uma pretensa neutralidade são mantidos pelos espaços de todas as filiais culturais interligadas em suas agendas e cronogramas: passa a ser imperativo que os trabalhos viajem e se adaptem a espaços distantes, que assimilarão tanto mais trabalhos quanto se mantiverem, digamos, mais básicos forem seus interiores. Parte da ideologia cosmopolita já dependia da possibilidade de trânsito sem muito atrito entre as chamadas culturas locais e certos internacionalismos. Uma sublimação na esfera da cultura para as frustrações de ordem político-econômica. A partir deste momento começa a vigorar uma diretriz que hoje me parece dominante: a adaptabilidade cada vez maior do trabalho de arte como condição para sua circulação.

O museu parece se comportar como fonte produtora de representações que preparam ou validam os terrenos conquistados ou a conquistar pelo capital. Se pudermos retomar as evoluções da imagem enquanto mercadoria, e as evoluções das atividades de um capital globalizado, arrisco dizer que 

a chamada arte brasileira (e acho que analogamente isto já valesse para a chamada arte latino-americana) só pôde ser assimilada neste circuito cultural internacional na condição de imagem.

É nesta condição que certas particularidades são apagadas em função de um discurso assimilatório. A imagem enquanto forma é o resultado da edição visual a que estes trabalhos, antes agindo em um contexto local que possibilitava um contato mais direto entre obra e expectador, têm de se submeter. Quando digo edição, me refiro à formulação de um discurso. Contudo, este se dá imageticamente, através de reproduções que não se limitam às tecnologias fotomecânicas. O museu, enquanto forma, está muito próximo da fotografia, e edição é seu ato fundamental. A transformação da cultura em comoditie depende deste mecanismo. Manifestações culturais são ajustadas ao formato de produto e circulam como mercadorias que, como culturais, têm o poder de alavancar o consumo de pacotes inteiros, destinados a modos desta nova vida contemporânea. $\mathrm{O}$ museu, entre outras coisas, assimilou a função de rubricar estes pacotes, torná-los legíveis para o consumo disto, que agora deve ser chamado de cultura, e que o discurso dominante se felicita por tornar acessível a todos que puderem arcar com as despesas.

Não afirmo, volto a dizer, que não haja tensão. Pelo contrário, não haveria ponto em investigar uma relação mimética destes trabalhos com certas formas do capital se estes revelassem apenas conformação. Minha escolha justamente leva em conta a qualidade que apresentam ao deixarem à mostra as tensões causadas pelo contato das ações com o mercado da cultura. Se não pudéssemos observar este conflito nestes trabalhos, não haveria nada para ver, já que a mimese se daria homogeneamente, como forma final, e não 

como um princípio que se contraponha dinamicamente a outros.

Tento evitar o risco de colar neste texto a própria encenação onde os trabalhos se tornam personagens com destino fixo e previsível. Em todo caso, não posso deixar de perceber como recorrente este aspecto cenográfico, para mim um elemento formal que se conecta ao modo como nossa visão de mundo se reconfigura.

Transgressão

A questão que tento formular é se esta forma cenográfica que pode ser isolada aqui e ali na trajetória de Cildo chega a possibilitar a consciência de nossa própria condição de sujeitos alienados das possibilidades de representação, necessária para nossa própria emancipação. Posto de outro modo: se a partir de um determinado momento já não é possível uma intervenção, em quaisquer sistemas ou discursos, pelo fato de as novas formas do capital, e com ele, o funcionamento mesmo de nossas relações com o mundo, já não mais serem passíveis de representação como a conhecíamos, esta forma cenográfica talvez esteja mais próxima de uma representação, digamos, mais realista de nossa atual condição. Como se o real tivesse se tornado ininteligível a ponto de ser menos enganosa uma forma que tenha no cenário um pressuposto formal. Este "simulacro" formalizado, para usar um termo controverso, não estaria mais próximo de um realismo justamente por explicitar sua condição de alegoria autônoma? 


\section{Através}

(1983-89) Redes, vidro, venezianas, cercas, grades, arame farpado, correntes, corda, bola de celofane. Área aprox. 225m.

11: Agradeço a Rodrigo Naves, que, depois de pacientemente ter ouvido minhas idéias ainda rascunhadas para este texto, chamou minha atenção para a especificidade do "Através". 
Para isto, esta "forma cenário" deveria trazer em si a possibilidade de uma autoconsciência que lhe conferisse dimensão crítica. Uma investigação neste sentido talvez possa apontar para um trabalho que a meu ver se coloca como exceção à maior parte da produção de Cildo na década de 1980, o "Através" (1983/89). Investigação, claro, sem a expectativa de um veredicto.

"Através", trabalho pensado ao longo da década de 1980, parece estruturar-se a partir mesmo da contradição entre esta formalização cenográfica e seu entorno, por ser, por assim dizer, um cenário inabitável ${ }^{11}$. $\mathrm{O}$ espaço autocentrado, presente em vários trabalhos que mencionei anteriormente, não fica aqui a serviço de algo que se encena em seu interior, apontando para uma pretensa autonomia. Serve como fechamento, mas não como palco. Não acolhe o sujeito como um ambiente de uma experiência estética privilegiada, antes oferece os limites físicos impostos por seus elementos de constituição, grades e barreiras de todo tipo e tamanho, como condição mesma de sua estada num entorno que, por não se relacionar com ele em conformidade estética, mantém independência ou autonomia, mas uma autonomia crítica, para que lhe seja justa enquanto representação mais realista. Não há malabarismos como o mero impedimento físico aos passantes. Ao invés disso, está posto o constrangimento da condição de passante como única possibilidade de fruição. Todo o real está tomado e não se oferece nenhum tipo de remissão ao expectador. $\mathrm{O}$ espaço é problematizado como algo guardado. O que talvez seja suficiente para que possamos chamar de uma operação de contra-discurso é o fato de não oferecer ao expectador nenhuma satisfação imediata, nenhum tipo de liberação sensória.A resistência se dá por conta mesmo de uma problematização explícita da impossibilidade de transgressão. 
12: Em MEIRELES, C. “Cildo Meireles”. London: Phaidon, 1999

13: BORGES, JORGE LUIS. "O Fazedor". São Paulo: Difel, 1984

14: Uma digressão; Há algo de muito próximo entre o relato seco de Althusser e o conto de Borges. Ambos parecem ser vítimas de uma espécie de nostalgia irreparável de vivências infantis. Em Borges os espaços dados ao sujeito são feitos de uma memória tangível, e por isso os tempos são interpenetráveis como cômodos de uma grande biblioteca. Nota-se um gosto infantil de mover-se por estes espaços deslumbrando-se com uma série de primeiras vezes, e de aproveitar este deslumbramento com o mundo que inevitavelmente se perde quando as explicações pas- 
Não-ficção

É curioso como o escritor argentino Jorge Luis Borges parece ter se tornado referência literária obrigatória quando se pretende discutir questões ligadas ao simulacro e a representação no estudo da arte. Asseguro que não era minha intenção citá-lo. Pessoalmente teria escolhido antes outros autores menos consagrados. Relato apenas que Cildo, em livro dedicado ao seu trabalho ${ }^{12}$, numa seção chamada "The artist's choice", escolhe Borges como referência. Ali, o famoso conto de Borges, "O jardim de caminhos que se bifurcam", é editado como que interagindo com reproduções fotográficas de "Através" e alguns rascunhos referentes ao seu projeto. Relendo alguns de seus contos e poemas, fica evidente, como relação possível, uma constância de reflexões sobre representação. Além do clássico que é escolhido no livro, me parece importante mencionar "Museu", um pequeno conto que se encontra em "O Fazedor"13. Neste conto, é narrada a fatura de um mapa, tão fidedigno ao império representado, que coincidia com este, ponto a ponto. $\mathrm{O}$ tal mapa é abandonado pelas gerações posteriores à ação do tempo e da natureza ("as inclemências do sol e dos invernos"), e hoje o que resta são as ruínas do mapa, habitadas por animais e mendigos.

Nas narrativas de Borges só há de fato a ficção ${ }^{14}$. Vivemos desta "crassa mitologia", trocando de máscaras em função da repetição dos atos. A circulação se dá pela própria representação, pelo ato de nomear, de imaginar. Como em "Museu", os espaços planificados de nossas representações obcecadas por controle não resistem ao tempo. O que não as impede de permanecerem como ruínas 
sam a constituir mais a experiência do que uma ignorância saborosa. Inversamente em Althusser também é descrito um mundo perdido, em decorrência da consciência trazida por cada uma das ideologias que se substituem sucessivamente no assujeitamento do indivíduo.

15: Ou ainda uma outra possibilidade, ou talvez todas as possibilidades que pudermos elaborar. Teorizar sobre ficção, aferir seus trajetos, medi-los, talvez corresponda a atitude que leve a criação deste mapa. $\mathrm{O}$ abismo sedutor que significa guardar o mundo em suas medidas. $\mathrm{O}$ ato incompreendido para quem foi seduzido pela ilusão controladora do arquivo é o que resta de sanidade a Don Alejandro, personagem de outro conto de Borges, "O Congresso", que ordena a queima dos registros, das atas, dos livros: "_Quatro anos levei eu a compreender aquilo que vos digo agora. $\mathrm{O}$ empreendimento em que estamos metidos é tão vasto que engloba - sei-o neste momento - o mundo inteiro. [...] $\mathrm{O}$ Congresso do mundo começou com o primeiro instante do mundo e há de prosseguir quando formos pó. Não há lugar em que ele não esteja. O Congresso é os livros que queimamos. O Congresso é os caledônios que derrotaram as legiões dos Césares. O Congresso é Job em plena esterqueira e Cristo na cruz. O Congresso é aquele rapaz inútil que desperdiça o meu gado com as rameiras." Todas as possibilidades que pudermos elaborar ou ainda uma outra: a deste mapa roto, habitado por mendigos, ser lido como toda teoria, que já ganha a mesma dimensão da ficção que teoriza.

\author{
Marulho \\ (1991-97) Deck de madeira, \\ livros, e trilha sonora. Dimen- \\ sões variáveis. Instalação, \\ Bienal de Johannesburgo.
}


habitáveis. Seriam estas ruínas os espaços periféricos que habitamos, em reprodução ao império? Ou como metáfora do saber científico, do museu enquanto signo da cultura, da possibilidade de experiência e sobrevivência em um mundo onde a representação se torna o real possível ${ }^{15}$.

A recontextualização destes contos de Borges talvez tenha o mérito de nos situar na discussão sobre representação, ou mais, a representação como campo de disputa, e a partir das possibilidades de representação no mundo contemporâneo, a disputa de poder travada no campo discursivo.

Oposição

Em "Marulho" (1991/97) é quase uma paisagem inteira que se cenografa. Novamente um ambiente é criado para o sujeito, um ambiente dentro de outro, o museológico. Em "Ku kka ka kka" (1999) esta forma cenográfica adquire uma eficiência máxima em termos de adaptação ao espaço do museu. Este trabalho é composto por duas estufas de vidro, onde estão expostos vasos de flores. Em uma delas, as plantas verdadeiras convivem com excrementos falsos. $\mathrm{Na}$ outra se dá o inverso. O aspecto vitrinesco destas estufas ressalta o papel de galeria do espaço expositivo. Estas vitrines dispostas simetricamente determinam sua leitura pela relação entre si e não com seu entorno, espacialmente falando. Podemos ver, então, na autonomia desta metáfora, uma potencialização da ironia em relação ao circuito, ou sua mera adaptação a este. Uma inversão do discurso a 


\section{Ku KKa Ka KKa}

(1999)

Flores, flores de plástico, excremento, excremento de plástico. Vitrines de metal e vidro. Dimensões variáveis. 
partir da mimese, ou uma realização formal de forças irrepresentáveis, além de uma abstração disponível.

Se a arte pode perceber a si mesma, num movimento reflexivo, como parte da alienação, a forma cenográfica destes trabalhos pode significar um processo crítico que, a partir desta percepção do real, passa a refletir a condição inverossímil de qualquer representação que não se dê já de saída como cenográfica, assumindo o cenário como forma icônica para a encenação.

Encenação como recusa da ilusão, um não crer que mantém consciência, mas que observa o jogo com interesse, e assim compreende sua dinâmica oculta.

Retomo, do início deste parêntesis, os dois procedimentos entre os quais oscilaram minha aproximação: o de uma intervenção precisa, e o de uma instalação cenográfica, que ao longo das transformações narradas aqui, passaram a circular preponderantemente por meios diferentes. As instalações que encenam são revividas pelo circuito internacional de arte, e circulam no campo da imagem em que vive o museu, possibilitadas pelo funcionamento cultural hoje. Enquanto que as intervenções, procedimentos de cunha conceitual, ainda circulam enquanto experiência no meio discursivo de seus relatos, que são, no trabalho de Cildo Meireles, um espaço de atuação, tanto quanto a circulação na economia ou o circuito fechado dos aparatos culturais. 

Nesta bifurcação potencializam-se ainda relações entre os dois campos, como neste meu exercício, dependente de uma escrita organizadora de memória, ou antes, de uma memória que produz experiência por meio da escrita. Se ainda falamos de "Inserções..." como um trabalho que opera de dentro de discursos, isto se dá em vários níveis e possibilidades de interlocução, e em vários tempos diferentes. Este mesmo texto pode ser lido como desdobramento daquela ação. 



\subsection{Processo e fracasso}

Era preciso que enfrentássemos o espaço expositivo. Pensamos em um desenho inicial para o espaço, uma estrutura que se contrapusesse a um outro elemento, que agiria nas superfícies, que criasse um espaço outro a se sobrepor e contrapor aquele que se nos havia sido oferecido, aquele em que estávamos. O brilho de que fala a descrição do projeto. A opção pela estrutura veio da necessidade de reorganizar o espaço de modo a revelar as paredes falsas e sua relação com o exterior do prédio. Era uma maneira de fazer com que o espaço que funcionava como recuo para a apreciação de obras que pendiam das paredes, que validavam a obliteração de seu desenho, suas entrâncias, ângulos e suas janelas, criasse alguma resistência. Daí o outro elemento, a pintura, que fizemos assumir a dupla função de apontar para o exterior, para que revelasse sua contradição com a configuração ambígua dada ao espaço pelo Artenexo, e criasse este outro espaço, que funcionaria para um deslocamento espacial de algo como uma instancia superior de experiência, travada acima dos passantes.

Falar de como se fizeram as idéias parece inócuo. Se havia idéias, fazíamos com que conversassem. Não dividíamos tarefas. Contrapúnhamos pequenos resultados a outros, discutindo esta forma que se alterava a cada questionamento. O processo de colaboração é feito de discussão, argumentação constante. E quando tudo isto falha, é estratégia, manha, e até um certo tipo de chantagem intelectual. E por um momento ou outro voltávamos a discutir os detalhes que nos pareciam fundamentais para o trabalho. Levávamos nosso fracasso muito a sério. 

Pedi a Carlos que elaborasse um relato da experiência de Workplace/Werkplaza, do qual reproduzo a parte que trata desta primeira aproximação com o espaço do Artenexo:

“ [...] Fomos visitar o espaço, um centro comercial com salas de escritório que disponibilizou duas para o projeto. A primeira sensação, acho que de ambos, foi o pé direito baixo dessas construções. Começamos em cima disso a pensar. Precisávamos deixar essa sensação um pouco pior, o branco brilhante suspenso foi o elemento que talvez desse esse efeito. Só que precisávamos de algo que o mantivesse suspenso. Pensamos, então, na estrutura central feita com o mínimo de elementos para mantê-la em pé. Mas essa, frágil, não conseguia cumprir sua função, a massa branca a atravessa na parte superior. Mesmo ocupando o espaço repetindo um desenho funcional considerando a possibilidade mais simples para apoios de sarrafos de madeira, isso ficou com uma aparência precária - um observador falou em barraquinhas de festa junina de interior, outro, na parte de baixo de um píer. Essa aparência precária não estava completamente fora do nosso horizonte, tinha que ser uma estrutura de sustentação que não conseguia sustentar a massa invisível branca. Na minha ingenuidade, achei que o cuidado, entre todos os outros, de procurar uma correspondência ao brilho do branco na madeira fosse suficiente para evitar essa leitura, o que obviamente não aconteceu como pude ouvir em alguns depoimentos. A alcunha de minimal apareceu em outros, como no trabalho anterior. Mas alguns depoimentos, de pessoas que não eram do ramo, saíram desses lugares comuns culturais e propuseram leituras interessantes: o observador que falou na estrutura de um píer, notou, em seguida, que as coisas parecem acontecer no píer, que estamos nessa subvida a espera daquilo que não 

alcançaremos; ou outro que questionou certa obsessão dos "artistas" com a reiteração da forma de estrutura, como se a lógica ou racionalidade no trabalho fosse mais uma espécie de ritual do que um elemento orientado para algum meio de esclarecimento. A realização desse que foi meu último trabalho - e, ao que parece, continuará sendo - mais essas trocas que nos recolocam de frente com o que fizemos, formam o resto dessa interessante, do ponto de vista individual apenas, e fracassada experiência."

Sim, falar de Workplace/Werkplaza (Wp/Wp) talvez seja narrar um fracasso. Mas em relação a quais objetivos?

Num primeiro momento, aos objetivos que sentíamos como demanda do próprio Artenexo, personificado ali por seus organizadores ou produtores. Não que tenhamos sentido algum tipo de pressão. A empreitada toda era de tal insignificância que não poderia justificar nada nesse sentido. Mas havia a postura de quem, tendo isso por negócio, esperava que houvesse algum tipo de resultado estético aprazível que se encaixasse no gosto do financiador. Ou que pelo menos cumprisse as tarefas que qualquer produto da indústria cultural costuma cumprir.

Num segundo momento, pode-se colocar a demanda do Artenexo enquanto projeto, que se podia ler em sua configuração: um produto que reverberasse os discursos a que tenho me referido, que se contivesse ao lugar e função que todo o projeto havia reservado para a arte: o de objeto enfeitiçado que justificasse a criação de um espaço cultural. Em relação a estas expectativas, parecia fazer sentido que estivéssemos trabalhando no Artenexo, um canto 

esquecido de um circuito cultural para além de secundário. Era necessário fazer algo a altura deste aparelho cultural. Quanto a isso, me parece, fomos bem sucedidos.

Para nós era importante não nutrir nenhuma ilusão em relação às possibilidades de inserção social, de criação de interlocução com esta abstração que de hora em hora é reclamada para justificar todo tipo de ação de viés paternalista: "o público". Afinal, é de resultados sociais quantificáveis e verificáveis que dependem hoje a liberação de verbas para qualquer ação que, se utilizando do discurso ligado ao campo de produção contemporânea das artes, se presta a viabilizar ações sociais paliativas que potencializem as adaptações exigidas pelo movimento do capital pela cidade.

Mas, para além destes momentos, talvez o fracasso significasse para nós a única condição possível para que se mantivesse o caráter negativo daquela ação. Um "bom trabalho" é juízo devedor de uma noção cristalizada de intervenção, quando vista de fora dos contextos, pelo grupo restrito que já assimilou uma postura pseudocritica como fórmula de análise. Agradar a nós mesmos, educados que estamos para a ironia facilmente desmontável da arte contemporânea, já nos faria desconfiar de sua possibilidade crítica.

A autonomia do trabalho por si não poderia validar sua potência. Ele deveria se alimentar de uma autonomia que cortejasse a dissolução de si nas estruturas de Workplace, sem, no entanto, ceder a elas. O trabalho estaria assimilado no momento mesmo em que se apresentasse como a imagem do absurdo associada à produção de "arte contemporânea", exposta naqueles escritórios adaptados. Por outro lado não bastaria ser similar a situações típicas do edifício como que para denunciá-las. Em nenhum momento 
1: Algumas questões que ficam como apontamentos para estudos futuros (tendo em mente as evoluções de que tratei em minha aproximação com o trabalho de Cildo Meireles): esta forma de intervenção artística, baseada em um proceder que pensa ações pontuais abstraindo contextos para neles intervir, enquanto fenômeno cultural, não estaria afiliada aos procedimentos acionados pelo grande capital, impostos mundialmente a partir da década de setenta e, portanto, não traria nos seus procedimentos o indício mais evidente de adesão em relação às competências postas como condição de atividade deste capital recente?

Os modos de atuação deste tipo de produção artística orientada para a especificidade do lugar dependem, no jogo econômico das relações de trabalho entre artistas e empreendedores culturais, de uma relação demandante de propostas e projetos artísticos. Esta relação, ao mesmo tempo em que valoriza o desenvolvimento de um olhar para a especificidade de cada situação, também exige do trabalho, na mesma proporção, um tipo especial de adaptabilidade. Num panorama geral, a diferença entre as situações é supervalorizada, em reforço negativo do que é comum a toda atuação hoje, ou seja, uma predominância dos procedimentos desse capital volátil, já que o jogo do qual participam estas situações é sempre o do capital. A demanda do lugar passa a ser, na verdade, a de que se realce sua singularidade em meio à planificação e padronização que ganha terreno, e não que se revelem as contradições de sua estrutura, nem que exponha sua identidade ideológica em relação ao jogo do qual faz parte.

Qual então a possibilidade de se criar alguma resistência por meio de uma forma tão similar a do discurso hegemônico? Não estaria qualquer intervenção presa à imitação das dinâmicas do espaço econômico responsável pela realização dos espaços com que esta dialoga, e desse modo, funcionando para sua reprodução?

Apesar de estas questões rondarem meu olhar sobre $\mathrm{Wp} / \mathrm{Wp}$, sei da complexidade e abrangência com que um estudo deveria arcar para discuti-las a contento. Mantenho como nota para que me mantenha perguntando. 
Wp/Wp colocava a dúvida de que não pertencia, enquanto forma, àqueles espaços ${ }^{1}$.

Em seu relato, Carlos menciona como marco de chegada a sensação de achatamento que diz ter tido naquele espaço. Ele recupera outra função do brilho: acentuar esta sensação de achatamento. Ao falar da estrutura que deixaria o branco brilhante suspenso, também acusa sua incompetência em funcionar como apoio, como se realmente esperássemos que cumprisse esta tarefa. Alguns elementos do trabalho já funcionavam no todo de modo a expor certas impossibilidades, marcando oposição à ideologia do espaço Artenexo. 

Aparecem também umas poucas vozes que se dispuseram a alguma interlocução, construindo analogias com as formas presentes. Estas falas ficaram para mim como retorno cultural. $\mathrm{Wp} / \mathrm{Wp}$ parecia haver tocado de algum modo um imaginário considerado popular, fazendo-o reagir. Ficava claro ali o esforço de relação ou conexão entre o que se presenciava e uma ou outra imagem que guardasse uma experiência de mundo. Estas experiências também chegavam como relatos, já que estas formas análogas (barracas de festas populares ou piers), vinham condicionadas à narrativas que as moldavam.

Mas o que mais me chama atenção, é claro, foi o modo como o termo fracasso aparece como conclusão e ao mesmo tempo como que uma abertura para uma categoria moral, uma condução ética da relação entre obra, trabalho e contexto. Uma condição fundamental para a arte, como se fosse inevitável e mesmo preferível. Afinal, pensar em sucesso significaria sujeitar o trabalho de arte à mesma lógica que o Workplace parecia encarnar. Qualquer sentido de sucesso, naquele contexto, significaria imediata adesão ao espaço. Se a crítica que apontava a ritualidade do apego à estrutura era válida, também garantia nossa possibilidade de frustração com o resultado. Contanto que ela entrasse como um "apesar de", como uma resistência que, apesar de frustrada, não houvesse se entregado facilmente. 
1: Contudo, qualquer questionamento em relação à potência de WP/WP se dará dentro mesmo de seu desdobramento discursivo, logo a narrativa deve abarcar também estes questionamentos; afinal a descrição citada já não antecipava algumas das questões previamente colocadas e já não funciona internamente a partir delas? Por isso aponto, nas notas subsequentes, para algumas partes de minha descrição que vejo como antecipações dos pontos pelos quais se desdobra esta tentativa de análise.

2: "...uma estrutura composta de ripas de madeira que tomava todo o espaço das duas salas, exceto por um corredor de um metro de largura junto à parede. Esta estrutura de ripas era organizada por um padrão, uma espécie de célula de composição que se repetia e tinha continuidade em toda a extensão da estrutura..."

3: "À altura de dois metros pra cima foi estabelecido um limite; o espaço foi pintado com um tipo de branco diferente do expositivo, mais brilhante, no caso das paredes e teto. As partes das ripas que passavam desta altura foram pintadas com uma resina brilhante. De maneira que a sensação que se tinha era de que o 'brilho' havia tomado conta do espaço, vindo de cima, descendo até aquele limite um pouco acima das cabeças dos visitantes. Em uma das paredes, (a que havia sido construída tapando as janelas do edifício) este brilho continuava descendo apenas nos espaços em que se contrapunha ao desenho original das janelas, ou seja, formando placas e esquadrias de tinta brilhante nos lugares onde, se não houvessem sido cobertas, poderiam ser vistas as janelas do prédio. Estas "não janelas" brilhantes tinham como referência uma única janela que havia sido poupada e que também recebeu à mesma altura a cobertura de resina." 


\subsection{Considerações finais}

Cheguei a propor, em algum ponto deste relato, uma avaliação da dimensão crítica de $\mathrm{Wp} / \mathrm{Wp}$ em relação ao quanto de tensão este pode ter conseguido produzir em seus espaços de trabalho, como operou para desvelar as contradições dos discursos em que se inseriu ${ }^{1}$.

Embora não resultem, a meu ver, em uma forma cenográfica, há vários elementos em $\mathrm{Wp} / \mathrm{Wp}$ que guardam relação com elementos construtivos de Workplace. Trata-se de uma estrutura ${ }^{2}$ que se coloca a todo o momento como construção, ao contrário da construção em que se insere o trabalho, Workplace, que se coloca como imagem, que nega sua gênese construtiva. Seus materiais, apresentados como tendo em si mesmos sua finalidade, apontam para o interior do edifício, reverberando através de suas paredes móveis, realocáveis. $\mathrm{O}$ brilho ${ }^{3}$ que geralmente cobre, vela, esconde, chama a atenção justamente para a falta de brilho do que está acessível. Brilho que paira acima de nossas cabeças, mesmo sem muito encanto, revelando o desencantamento de todo o resto. Impossível determinar se tornado inacessível numa ascensão, ou se desce e escorre uniformemente do andar de cima, como uma condição, que apesar de previsível, se mostra inevitável. A revelação das janelas externas, pela pintura feita de brilho, recobrando a escala do edifício, oferecendo ao sujeito sua localização no entorno, na estrutura geral em que se encontra, sem, no entanto, oferecer-lhe a paisagem que, apresentada pela arquitetura como imagem, faria evitar a visão particular, a experiência do mundo, afastando o sujeito ainda mais daquilo que pode avistar. 
4:" Ao final, a estrutura propunha ao visitante que ele entrasse por uma porta de vidro e seguisse próximo à parede, contornando as ripas, como quem dá a volta ao redor de uma cerca. Este caminho, no entanto, deixava ver por entre as ripas toda a estrutura e os desenhos nas paredes. Enquanto se caminhava ao redor, o contraste entre o branco expositivo e a cobertura brilhante que descia do teto ia ficando mais visível. Como o percurso se dava próximo à parede, passava-se espremido entre os desenhos de janelas e a estrutura de madeira que, embora se assemelhasse a uma cerca ou jaula ou um destes suportes feitos em espaços fechados para reformas em tetos e coberturas, deixava à mostra seu funcionamento através de seus vãos (cada ripa guardava cerca de um metro e meio de sua vizinha mais próxima), além de sua precariedade enquanto divisória do espaço. Na verdade a estrutura não se validava nem como cerca, pelos espaços vazios, nem como suporte, por manter em todas ripas uma distância segura do teto, nem como estrutura em si por ser, apesar de visualmente limpa e geometricamente organizada, precária demais para suportar qualquer peso." 
Assim, muito do que se coloca como mimético, apenas aparece como oposição ao que se apresenta, e que não se apresentava antes justamente por não se contrapor a nada, por ser parte de um discurso inequívoco, opaco. Esta condição de opacidade, contraposta a si mesma, passa a produzir um certo espelhamento negativo.

Mas de forma mais contundente acredito que a tentativa de um contra-discurso se dê no tempo interno do trabalho, pelo movimento reverso do ritmo peculiar característico dos discursos que se colocam como o contexto em que se inseriu o trabalho. Se este ritmo conforma um continuum temporal, em Wp/Wp ele é exposto. Em oposição a este continuum, o tempo que o trabalho oferece como experiência; o tempo exigido para a experiência do trabalho ${ }^{4}$.

O trabalho não se mostra como mistério técnico, mas sim um questionar a partir do fazer, e logo, sobre a razão do fazer, ou seja, a origem do próprio trabalho, tanto de arte como de sua noção mais naturalizada. Expondo uma mecanicidade característica de qualquer função, expõe a funcionalização de todos os fazeres relacionados ao espaço de trabalho, e a racionalização destes fazeres, enquanto justificativa ideológica para as relações de trabalho.

Estando a construção, seus materiais, seus procedimentos e sua estrutura tão a mostra, o trabalho funciona, como uma espécie de célula ou núcleo referente ao ato de trabalhar, talvez uma representação icônica do trabalho e sua relação com o espaço institucional, empresarial. A economia da forma se dá pela própria austeridade de um fazer econômico em tudo: tanto nos materiais, como em seus procedimentos, prioriza-se o mínimo necessário, o suficiente apenas para seu estabelecimento. Assim o trabalho e sua economia operam como signos de Trabalho e Economia, sem que, no entanto, percam sua identidade de forma. 
5: "Ineficiente em tudo isso, também falhava em evitar a descida do teto deste espaço outro, que não reflete, do mesmo modo plano, a luz plana dos espaços expositivos."

6: Os módulos formados por três ripas de madeira afixadas remetem, impossível não mencionar, ao instrumento de tortura que deu origem à palavra trabalho (do latim tripalium, donde o verbo românico tripaliare, fonte do português trabalhar). Talvez tenha sido mesmo melhor que não tenhamos feito esta relação durante o processo de criação da intervenção, evitando que viesse a obrigar-nos a explicar a forma, colocando-a a serviço de uma ilustração. 
A relação de tensão, em relação ao espaço ${ }^{5}$, evita a abstração requerida pelo capital, sempre necessária para que a mercadoria não se identifique com seu fazer, o que exporia sua contradição. Ocorre uma reconexão entre as duas unidades últimas que circulam submetidas ao funcionamento do capital: o trabalho e a mercadoria. O discurso assim as apresenta, como duas pontas de um processo que perseguem uma a outra. São, contudo, partes de um mesmo corpo, faces da mesma moeda; se tudo pode ser convertido em valor trabalho, também tudo pode ganhar aparência de mercadoria sem passado, origem ou razão. Aqui, a obra de arte, já assimilada socialmente como uma espécie de mercadoria líder, como algo cujo preço de funcionamento é exatamente sua supervalorização, como algo que "naturalmente" estaria ali para que todas as relações de trabalho sejam legitimadas, como expressão do papel conciliatório da cultura, se volta para o espectador como mercadoria que trai seu destino, que revela seu processo de constituição, antes embutido, rascunho apagado da forma final. Volta-se como uma decepção, uma obra que fracassa em justificar o quotidiano de trabalho, contrariando a esperança de que o tempo entregue ao trabalho dê algum resultado: não há resultado apresentado por estas formas, há só um retorno ao seu processo de constituição, dirigindo a percepção do sujeito para os processos em que está inserido ${ }^{6}$. Uma antivitrine, que ao abarcar a passagem, pretende voltar o olhar do passante para sua própria condição.

Se trabalho e mercadoria perfazem circuitos continuamente, impulsionados por tal ritmo peculiar, o fazem como que espelhados, representados pela moeda. Este signo universal apenas mantém seu poder de significação enquanto mantiver sua capacidade de circulação. Talvez seja esta a circulação de que sente falta o indivíduo que 

percorre o corredor de $\mathrm{Wp} / \mathrm{Wp}$. Rodeia hesitante o produto de um esforço inútil, a reparar na precariedade da estrutura, sem nunca ser coberto pelo brilho que o faria semelhante ao dinheiro.

Wp/Wp não se oferece como um espaço convenientemente acolhedor, e embora não se coloque de forma tão cindida com seu entorno, como um cenário fechado, também se fecha para passeios do sentir, também se coloca como limite. Este limite abrange a circulação do espectador. Caminha-se, neste caso, no limite entre trabalho e espaço, por um corredor que parece estar prestes a ser eliminado pelo avanço da estrutura interna. Esta sensação, contudo, não se deve a nenhum efeito dramático ou ótico. Pelo contrario, se deve a percepção óbvia de seus materiais; ripas de madeira pregadas de forma simples e metódica, assim como o vazio entre elas, que afasta qualquer participação entusiasmada ou interatividade ilusória. Transforma o passar em um andar envergonhado. Aponta para o ato de circular como sendo de uma finitude pouco dignificante. Com isso contribui para que se revele a glamourização forçada do quotidiano circulatório dos espaços do prédio. Pela circulação é que se dá o ritmo, e pela impressão deste ritmo, a eternização de uma condição de permanente precariedade.

O sujeito que se via triunfante por obedecer a esta lógica, por ser submetido à circulação perene, que se justifica como meio e fim para tudo, se vê então num circular depressivo, sem missão. Parece-me que em Wp/Wp, o lugar do sujeito é desvelado e, ao mesmo tempo, proposto por este percurso, por esta desaceleração melancólica Não me refiro, evidentemente, ao ritmo físico do visitante que pode até caminhar mais rápido. Isto só poderia revelar o incômodo do trajeto, ou mesmo uma relação viciada de não leitura, de uma busca por signos imediatamente eficientes, 

freqüiente tanto nas auto-estradas quanto nos museus, mas que aqui é frustrada e termina sem resposta a cada vez que o percurso é realizado. Wp/Wp aponta para uma condição do sujeito de todos estes espaços que se instrumentalizam, mais do que uma critica ao espaço expositivo institucionalizado. A própria precariedade deste espaço específico (ArteNexo), sua tentativa tosca, embora amplamente divulgada, de se apresentar como um "cubo branco", signo de sofisticação, é absorvida pela intervenção como parte da estratégia; o prédio todo é frustrado em sua tentativa de exercer o papel a que se propõe, o de acolher e delimitar Cultura. Ocorre um refreamento do sujeito para quebra da condição rítmica do discurso em que se insere.

As lacunas deixadas pelo trabalho, sua falta de comando em relação ao expectador, ao mesmo tempo em que não lhe deixa alternativa, sua recusa em legitimar-se como "obra de arte", sua precariedade, são todas reveladoras da precariedade de seu entorno, da falsa liderança exercida por uma arquitetura autoritária, que é valorizada hoje como reafirmação de um gosto padronizado. O gosto formado e formador da ideologia dominante é questionado, sem que se proponha sua substituição por alguma outra forma de cunho apaziguador ou conciliador. $\mathrm{O}$ juízo nega que a forma seja arte, e a forma parece negar que o que lhe serve de entorno seja vida.

É por este percurso obrigatório existente em Wp/ Wp que se aproximam e se conectam dois sujeitos possíveis: o que se fundaria pela descrição e o que, através do primeiro, se tornaria possível. Tanto a narrativa que tenta dar conta da experiência passada no espaço da intervenção quanto a experiência proposta pela própria narrativa tomam forma pelo tempo.

Por uma sucessão de passos, dados pelo corredor 
7: "O que distingue a linguagem de todos os outros signos e lhe permite desempenhar na representação um papel decisivo... [é] o fato de ela analisar a representação segundo uma ordem necessariamente sucessiva: os sons, com efeito, não podem ser articulados senão um a um; a linguagem não pode representar o pensamento de uma só vez na sua totalidade; é necessário que o disponha parte a parte, segundo uma ordem linear. Ora, esta é estranha à representação.” ... “...substitui a comparação simultânea das partes (ou das grandezas) por uma ordem de que se deve percorrer os graus uns após outros. É neste sentido estrito que a linguagem é análise do pensamento: não simples corte, mas instauração profunda da ordem do espaço." Em FOUCAULT, M. "As palavras e as coisas". São Paulo: Martins Fontes, 1967 p 117. 
que resiste em meio ao espaço expositivo e a estrutura interna, é que se forma o lugar do sujeito em Wp/Wp, da mesma forma que, pela sucessão das partes, este se forma na narrativa que se inicia com a descrição da intervenção e continua por estas páginas. É a narrativa que reinstaura o espaço do trabalho ${ }^{7}$. O texto é o lugar ocupado por ele desde então. 
1: "Entretanto, uma vez que descobrimos o que é o objeto retratado, a fotografia instantaneamente transforma-se para nós- não mais um confuso conglomerado de tons claros e escuros, de bordas incertas e volumes ambivalentes, ela agora mostra uma 'coisa' que investimos de uma identidade plena, de um ser. Com a maioria das fotografias que vemos, essa decodificação e essa investidura ocorrem instantaneamente, inconscientemente, 'naturalmente"'. Victor Burgin, em Olhando fotografias. 


\section{Registro como lugar}

Pelo que me lembro, chegamos rapidamente a um consenso em como fotografar o trabalho. Um procedimento metódico, ainda que executado com certa pressa. Ao propor o projeto de análise da intervenção para a dissertação de mestrado, achei em meus arquivos este conjunto de imagens produzidas no espaço expositivo, que deveria cumprir a função de registro visual de Wp/Wp. Depois de havê-las procurado sem sucesso por um tempo, vê-las novamente resultou em uma divertida incredulidade. Foram necessários alguns minutos para que eu convencesse a mim mesmo de que se tratavam das mesmas fotos que havíamos feito no Artenexo naquela ocasião. Embora seu objeto fosse claro e os materiais presentes na intervenção estivessem ali visíveis, sua organização era outra. As relações entre material e forma, que se intensificavam sempre que me lembrava da intervenção, haviam sido substituídas por outras, como se o trabalho tivesse passado por uma remontagem caricata.

Não se trata de discorrer aqui sobre os limites e a impossibilidade, atribuída ao registro fotográfico, em conter a experiência original. Pelo contrário, o que sempre me espanta são as possibilidades da fotografia em originar experiências, fazendo com que seus temas passem a existir apenas em função de seu próprio registro ${ }^{1}$. 

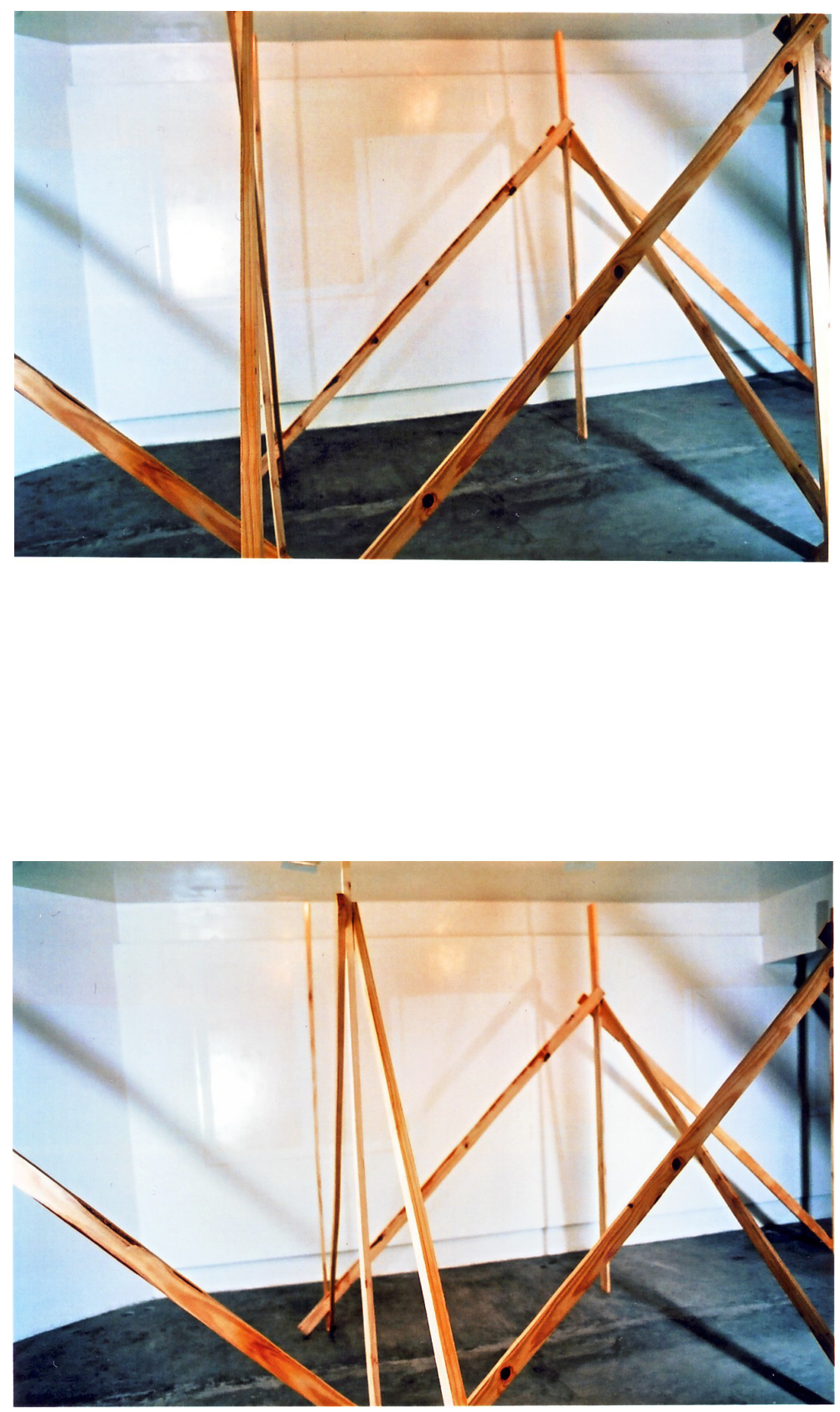
Mas em que consistia este nosso método improvisado? Em percorrer o trajeto que a fisicalidade da estrutura propunha ao visitante, fazendo da câmera o olhar de um visitante imaginário. Esta visão, que se construiria sempre a partir de pontos do trajeto, nos parecia a melhor opção para um registro que falasse das possibilidades de experiência presentes no trabalho. Sem dar-nos conta, estávamos construindo uma narrativa visual tão ou mais fechada do que o relato ordenado que transcrevi de meu projeto. 


$$
\frac{\Delta \mathbb{N}}{\Delta x}
$$


Contudo, mesmo esta narrativa poderia nos reaproximar de $\mathrm{Wp} / \mathrm{Wp}$ em alguma medida, justamente pela quase imposição deste percurso, pelo modo como havíamos ocupado as duas salas destinadas às exposições. Afinal a estrutura de ripas que tomava o espaço deixava para circulação um corredor que margeava as paredes externas de apenas um metro de largura.

Mas o efeito é o oposto porque cada um destes enquadramentos contradiz a especificidade do trajeto. Por que cada fragmento se afirma como um todo autônomo. Cada quadro reivindica para si a reutilização "original" dos elementos que antes víamos na intervenção, que, se no trabalho participavam de um conjunto de estruturas com certa organicidade, agora retornam revertidos em linhas e campos de cor que se cruzam e se sobrepõem, formando planos estanques junto a um branco pálido. O chão de cimento, as paredes pintadas de brilho, as ripas de madeira, são formas que, colidindo entre si, se solidificam no plano, reaparecendo como cor, tons e linhas. São, enfim, elementos de uma composição bidimensional; a estrutura do campo visual criado pela fotografia. 

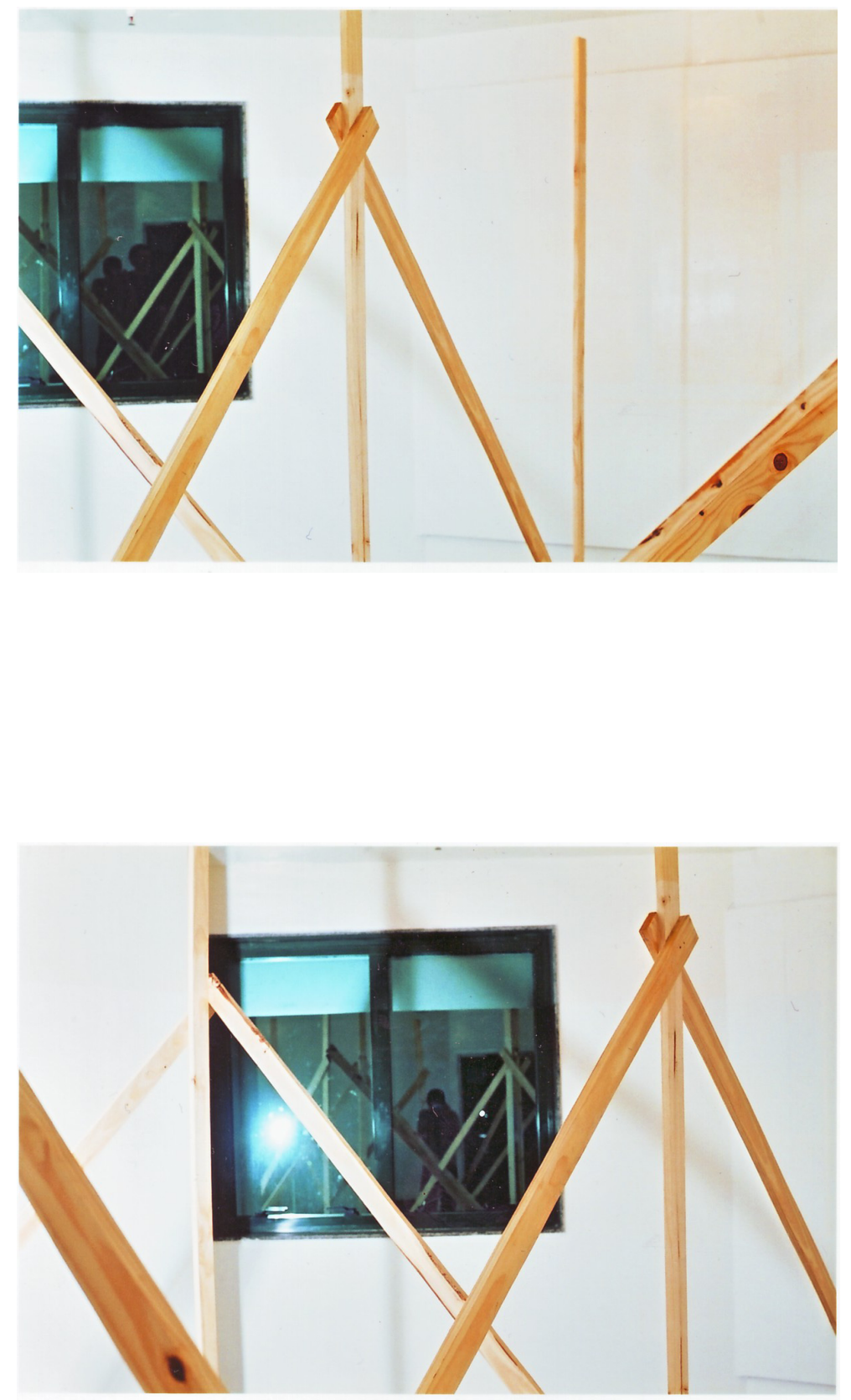
Além disso, essa organicidade a que me refiro no trabalho, funcionava de modo a não privilegiar visões do todo, ou de perspectivas abrangentes, oposto do que faz a fotografia. Ao caminhar por $\mathrm{Wp} / \mathrm{Wp}$, uma ponta de ripa coberta de brilho não cabia no mesmo momento perceptivo que o desenho das janelas. A estrutura se tornava inteligível pela sua modulação e não por se oferecer de uma só visada. A composição das fotografias despreza a relação modular da estrutura em favor do fragmento solto. Não admite outro princípio organizador que não seja o enquadramento pelo qual realiza a si mesma.

São estas imagens que agora são reativadas para este relato de $\mathrm{Wp} / \mathrm{Wp}$. Mas qual o papel que exercem neste novo meio de circulação? 


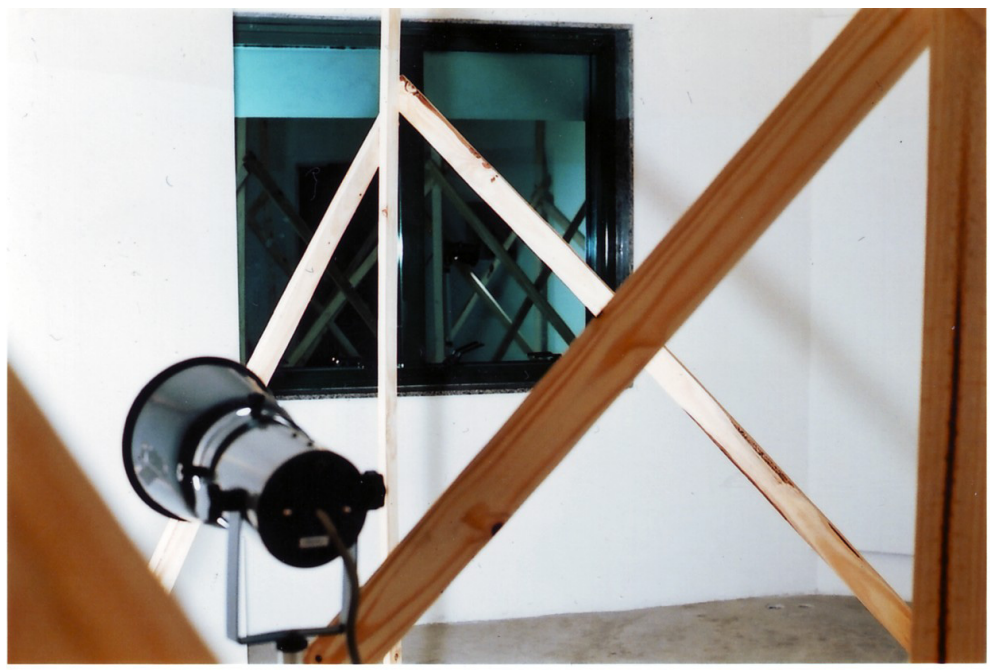


Uma das fotos feitas no espaço expositivo, antes descartada da função de registro, por um momento me parece reveladora destes limites: ela contém o holofote que por descuido nosso, aparece em meio à estrutura, conferindo volume e consistência à memória referente à intervenção. A explicitação do fazer (registro) parece aplacar as pretensões de uma visão totalizante. Contudo, passa a investir em nova estratégia: a promessa de revelar um momento único e valioso, como um desvendar de algo secreto.

O movimento para fora do campo ideológico é realizado pela consciência mesma de que não há como se permanecer fora dele. Uma reação ao movimento que nos impulsiona continuamente para o através, no esforço de se reter o que se esconde antes do apresentar-se da imagem. Um momento anterior à demanda de abstração ou talvez bem posterior. Ou, ainda, a tensão dinâmica que envolve tais momentos. Estar onde a foto não nos leva, ou seja, nela mesma. Se a câmera é o olhar mecânico, nosso olhar já é, em si mesmo, um meio, que talvez contenha possibilidades de um sentir a ser construído para além e antes da imagem. 
2: MALRAUX, A. “O Museu Imaginário”. Lisboa: Edições 70, 1965 
Texto como imagem

Já há algum tempo a fotografia é vista como um campo de reflexão possível, e não apenas como técnica de registro de produções anteriores, que a utilizariam como arquivo. No entanto, o caráter constituinte, em termos de produção, que desenvolveu a própria forma do acervo (e sua exposição) é freqüentemente obliterado. É como se fosse possível que a produção não guardasse conexão com a circulação destas obras. Como se, novamente, o arquivo pudesse ser neutro. O aparelho fotográfico e seus meios de circulação trabalham juntos em suas programações.

A fotografia que antes era vista como mídia, agora é vista como campo. No entanto é um pensamento fotográfico que parece ter sido transferido e ampliado para a esfera da cultura. No "Museu imaginário" de Malraux², este processo parece ser estruturante, até mesmo para a construção de seu texto.

Neste livro, o ritmo é marcado pela tônica das relações entre obra e artista, entre obra e as próximas obras de uma linha, como numa visita monitorada. É a história enquanto linha autônoma, mas consciente de seu pertencimento a um texto. Uma visão de Arte do ponto de vista da Cultura.

O operador de xérox, a quem peço que copie parte do livro, troca acidentalmente a ordem das páginas, o que resulta em mais uma comparação feita; um pequeno distúrbio na linha que não se rompe. Depois de quase cem páginas, a autoria do fazer, do classificar e o realizar museológico, começa a ser exposta mais claramente.

O próprio texto passa a agir pela colagem e a cita- 
3: "A Execução de Maximiliano de Manet é o Três de Maio de Goya, menos o que este quadro significa. Olímpia é a Maja Nua, assim como a Varanda é as Majas à Varanda, menos o que significam os dois Goyas." Idem: p45

4: "O Museu imaginário nasce de uma metamorfose tão profunda como aquela de que nasceram as primeiras coleções italianas: como os deuses antigos durante o Renascimento, os deuses que ressuscitam à nossa frente são amputados da sua divindade." Idem: p173

5: "Não há tradução.” Idem: p 237

6: FLUSSER, V. "Filosofia da Caixa Preta; ensaios para uma futura filosofia da fotografia". Rio de Janeiro: Relume Dumará, 2002 
ção exaustiva de obras e autores, ao mesmo tempo em que exige um esforço imaginativo, e portanto realizador - revela a inacessibilidade de cada um dos objetos a que se refere. Fica evidente que o raciocínio demanda o contato com todas as obras, logo o texto utiliza seus nomes como ilustrações (imagens que são). Nomes de obras e fotos ocupam como que o mesmo plano de potência ${ }^{3}$.

Aos poucos, as referências vão se destacando da linha, separando-se, entrecortadas, umas das outras, autonomizando-se. O mesmo ocorre com as ilustrações: antes expostas, agora sobrepostas e cortadas em detalhes que fazem outras obras, ou seja, imagens. Assim como os nomes das obras se tornam obras / relatos. A forma do discurso vai amoldando tudo em pela metamorfose, que no texto é conceito e processo que explica o nascimento do museu imaginário ${ }^{4}$ A imagem ou representação novamente demonstra sua dependência em relação ao tempo. O espaço novamente se dá pela narrativa, pela linguagem.

Interessante que a edição portuguesa do texto revele o nosso "detalhe" como "pormenor". Um termo se refere ao corte, outro à dimensão. Em italiano a tradução é "particolare". Faz lembrar o trabalho de Giovanni Anselmo, em que pequenas projeções da palavra "particolare" nos aparecem nas pernas enquanto andamos pelo espaço expositivo, procurando debilmente pela suposta exposição...5

Esta visão "cultural" da arte se dá por uma forma fotográfica, imagética. Arte como ilustração de uma grande narrativa em linha. E tal procedimento, estratégia ou visão fotográfica vaza para os próprios procedimentos, ações ou estratégias culturais. $\mathrm{O}$ olhar totalizante, o olhar que se mostra como neutro, o olhar realizador que se naturaliza. $\mathrm{O}$ aparelho, como definido por Flusser ${ }^{6}$, contamina e conforma os meios de circulação, e vice versa. $\mathrm{O}$ museu funciona 
7: "Um fato de primordial importância social é de que a fotografia é um local de trabalho, um espaço estruturado e estruturador dentro do qual o leitor distribui, e é distribuído por, quaisquer códigos com os quais ele ou ela tenha familiaridade, de modo a fazer sentido." Victor Burgin, em Olhando fotografias.

Fotos: Carlos Pires e Gilberto Mariotti 
fotograficamente, e também todos os aparelhos culturais.

Fotos de trabalho

Ao reaparecerem aqui como discurso, estas fotos não se colocam como representação de $\mathrm{Wp} / \mathrm{Wp}$. Realizam o próprio espaço expositivo do ArteNexo em associação a lógica cultural pela qual este se amoldava. A fotografia, seus procedimentos, sua visão, é já um lugar de trabalho ${ }^{7}$, pelo qual se realizam as imagens, a forma de um discurso atualmente plenamente hegemônico. Se o Wp/Wp demonstrara alguma resistência em relação aos seus contextos, era a função dessas fotos aplainá-lo, ordená-lo, prepará-lo para os meios de circulação subseqüentes ao espaço expositivo em que ocorreu. Se com alguma força a intervenção pôde evitar o brilho que a tornaria imagem atraente, restou ao proceder fotográfico buscar uma certa esterilização de seus elementos mais poderosos. Uma evidência, pois, de alguma potência contida em $\mathrm{Wp} / \mathrm{Wp}$, deve ser o fracasso destas imagens enquanto elogio da intervenção. São ridículas. Isto talvez se deva a resistência da intervenção à sua planarização. $\mathrm{Ou}$ então, simplesmente, ao fato de ter podido enfrentar dois fotógrafos que, com ela, estavam predispostos a uma boa dose de conivência. 
1: Este talvez seja o deslocamento que ritualiza todo o circuito perceptivo da arte, mais até do que o deslocamento contínuo das obras pelos circuitos econômicos impulsionados pela mercadoria-obra hoje: o deslocamento do trabalho que deixa vago o lugar para sua descrição. Não o relato ou narrativa como possibilidade de experiência, de que sentia falta Benjamin em seu "O Narrador", mas a narrativa que se acredita estar a cargo das imagens. Como num outro salto, como descrito por Flusser, do texto para a imagem de funcionamento opaco, que ideologicamente se mostra como descrição. 


\subsection{Releitura}

Ao reler minhas considerações sobre a dimensão crítica de $\mathrm{Wp} / \mathrm{Wp}$, escritas antes do exame de qualificação pelo qual passaram, sou obrigado a me perguntar se, pelo relato, não manobrei o espaço da dissertação para que este acolhesse a possibilidade de validação do trabalho. É possível que os juízos tenham acontecido como uma conseqüência maquinal do andamento da narrativa, do encadeamento de idéias e cenas. Contudo, o relato, enquanto forma, ainda guarda a possibilidade de crítica na medida em que não pretender um posicionamento privilegiado, externo ao relato mesmo.

Sendo minha posição parcial, assumi o lugar de quem, ao narrar, oferece outra experiência, em prejuízo da que tive e que agora transformo. O relato toma o lugar do trabalho. Não é o trabalho, não relata o trabalho, não representa o trabalho ${ }^{1}$.

Assumir este lugar criticamente pressupõe reconhecer como esta posição determina minhas percepções, assim como determina o modo como construo narrativas que se servem delas. De alguma forma, o relato do que se leu aqui ainda deveria continuar a apontar para a pergunta sobre o que se pode realmente ver, e sobre o que se é capaz de ler. E se não posso oferecer Wp/Wp a uma crítica distanciada, ao menos pode ser objeto de crítica este relato.

Ainda resta mais um movimento a fazer: reler estas últimas considerações como discurso que valida $\mathrm{Wp} / \mathrm{Wp}$ a fim de discuti-las. Enquanto ainda posso, levanto alguns pontos para os quais proponho questionamentos que talvez sejam disparadores de novas discussões. 
2: "Embora não resultem, a meu ver, em uma forma cenográfica, há vários elementos em $\mathrm{Wp} / \mathrm{Wp}$ que guardam relação com elementos construtivos de Workplace. Trata-se de uma estrutura que se coloca a todo o momento como construção, ao contrário da construção em que se insere, que se coloca como imagem, oferecendo aspectos construtivos apenas para que se obliterasse sua gênese construtiva."

3: "Seus materiais, que apresentados como tendo em si mesmos sua finalidade, apontam para o interior do edifício, reverberando no interior de suas paredes móveis, realocáveis. O brilho que geralmente cobre, vela, esconde, chama a atenção justamente para a falta de brilho do que está acessível. Brilho que paira acima de nossas cabeças, mesmo sem muito encanto, revelando o desencantamento de todo o resto. Impossível determinar se tornado inacessível numa ascensão, ou se desce e escorre uniformemente do andar de cima, como uma condição, que apesar de previsível, se mostra inevitável. A revelação das janelas externas pela pintura feita de brilho, recobra a escala do edifício, oferecendo ao sujeito sua localização no entorno, na estrutura geral em que se encontra, sem, no entanto, oferecer-lhe a paisagem que, apresentada pela arquitetura como imagem, faria evitar a visão particular, a experiência do mundo, afastando o sujeito ainda mais daquilo que pode avistar." 
A começar por esta aparente contradição entre os elementos que poderiam ser considerados construtivos, presentes ainda no espaço Artenexo e em Workplace de modo geral, e o movimento que encobertava a construção do edifício ${ }^{2}$. Ocorre que tais elementos pareciam ter sido deixados como pistas, ou sobras de um momento construtivo, e que ideologicamente poderiam conferir algum valor a Workplace, numa tentativa de conexão simbólica com o mundo do trabalho que o nome do empreendimento prometia. Mas exatamente por sobrarem, estes elementos deixavam ver a total falta de organicidade entre forma e função proposta por seu projeto arquitetônico.

Sobre a amarração formal do trabalho, chegamos a nos perguntar se esta dicotomia entre estes dois planos (um acessível ao espectador, outro que acontece acima pela diferença de brilho) poderia apontar para uma mistificação do que estaria inacessível, orientando o olhar para este patamar acima como uma instância liberadora ou conciliado$\mathrm{ra}^{3}$.

A maneira como estes dois espaços se relacionam não me leva a crer que esta leitura fosse possível. Esta camada de brilho, descendente ou ascendente, só revelaria a repetição do espaço pela lógica de sua construção. Acho ainda que a relação produziria a desmistificação de uma instância de idealização que se reproduz indefinidamente. Esta questão talvez demonstre menos pertinência em Wp/ Wp do que quando aplicada a este exercício de revisão, que também se estrutura a partir de uma separação de espaços para a construção de um meta-discurso.

Ainda medindo o fracasso, me pergunto se o trabalho, ao investir em uma certa precariedade, não foi ca- 
4: "Assim, muito do que se coloca como mimético, passa a aparecer como oposição ao que se apresenta, e que não se apresentava antes justamente por não se contrapor a nada, por ser parte de um discurso inequívoco, opaco. Esta condição de opacidade, contraposta a si mesma, passa a produzir um certo espelhamento negativo."

5: "Mas de forma mais contundente acredito que a tentativa de wpwp de oferecer alguma resistência tenha se dado no tempo interno do trabalho, pelo movimento reverso do ritmo peculiar que pude identificar como elemento formativo do discurso da lei mendonça. Se este ritmo conforma um continuum temporal, em $\mathrm{Wp} / \mathrm{Wp}$ ele é exposto em oposição a este continuum, o tempo que o trabalho oferece como experiência; o tempo exigido para a experiência do trabalho." 
paz de produzir tanto contraste em relação ao Artenexo ou mesmo Workplace quanto esperávamos ${ }^{4}$. Por outro lado, como o trabalho poderia se relacionar de forma crítica com o entorno sem um primeiro movimento mimético? A criação de diferença pura e simples não condenaria $\mathrm{Wp} / \mathrm{Wp}$ a pretender a produção de um espaço idealizado, adaptável a qualquer situação? Ainda penso que era exatamente num primeiro movimento de mimetismo que se fundava a possibilidade de crítica de $\mathrm{Wp} / \mathrm{Wp}$. Este havia de investir e se apropriar do mesmo, para que se evidenciassem as formas que, nesta situação, haviam se naturalizado. Assim, racionalizar certas circunstâncias não significava aderir à ideologia. Mas terá significado fracasso, se o resultado tiver chegado próximo demais da precariedade a ponto de, ao invés de subvertê-la, continuá-la. Certamente que a dificuldade está em evidenciar algo, de dentro da situação, sem produzir mais um segmento do espetáculo vigente.

Mas acho que, afinal, um trunfo do trabalho era que sua estratégia não pressupunha a revelação repentina de um todo mais abrangente. Aliás, não propunha revelação, no sentido de que o trabalho não funcionava a base de sinapse como um ganho de percepção.

Ao falar deste tempo ${ }^{5}$, que era para mim uma matéria importante para o trabalho, refiro-me, não ao tempo exigido como pressuposto para uma compreensão adequada do trabalho, mas ao tempo que o percurso exigia. E principalmente ao modo como a própria fisicalidade da estrutura criava um percurso de visão, fazendo com que o espectador participasse, com a forma mesma, de sua própria edição. Ainda estou certo de que ela forçava um movimento reverso, de resistência mesmo à experiência temporal oferecida pelo prédio. Ao invés de "resistência", talvez eu pudesse 
6: "O trabalho não se mostra como mistério técnico, mas sim um questionar a partir do fazer, e logo, sobre a razão do fazer, ou seja, a origem do próprio trabalho, tanto de arte como de sua noção mais comum. Expondo uma mecanicidade característica de qualquer função, expõe a funcionalização de todos os fazeres relacionados ao espaço de trabalho, e a racionalização destes fazeres, enquanto justificativa ideológica para as relações de trabalho." 
dizer "trava" ou "cunha", como para uma ligação mais direta com a aproximação que propus com os trabalhos de Cildo dos quais tratei mais ao início de minha aproximação. Poderia também dizer "tensão". Mas a aproximação com o trabalho de Cildo me faria ver ainda que este andar pelo espaço deixado entre estrutura e parede pode muito bem se assemelhar ao andar por dentro de certos trabalhos que, em um segundo momento da aproximação, entendi como estando mais próximos de uma forma cenário. Teríamos transformado todo o Artenexo num cenário? $\mathrm{Wp} / \mathrm{Wp}$ teria ficado mais próximo então de uma instalação do que uma intervenção? Estou propenso a achar que é a forma pela qual o percurso se mantinha entre o espaço expositivo e estrutura, que garantia a $\mathrm{Wp} / \mathrm{Wp}$ a possibilidade de explorar uma tensão que uma instalação não teria. Isto por que um cenário, por definição, teria de encobrir o espaço para se realizar como nova referência. O movimento de $\mathrm{Wp} / \mathrm{Wp}$, ao contrário, era de descoberta.

Há este momento em que minha crença nas possibilidades de $\mathrm{Wp} / \mathrm{Wp}$ ultrapassa o limite do bom senso... ${ }^{6}$ $\mathrm{Se}$, ao discutir o processo do trabalho ligado à expectativa de fracasso, eu dizia da desconfiança que me traria a sensação de sucesso a reboque de uma ironia facilmente legível para um certo grupo de espectadores, ("Mas, para além destes momentos, talvez o fracasso significasse para nós a única condição possível para que se mantivesse o caráter negativo daquela ação. Um "bom trabalho" é juízo devedor de uma noção cristalizada de intervenção, quando vista de fora dos contextos, pelo grupo restrito que já assimilou uma postura pseudocritica como fórmula de análise. Agradar a nós mesmos, educados que estamos para a ironia facilmente desmontável da arte contemporânea, já nos faria 
7: "Estando a construção, seus materiais, seus procedimentos e sua estrutura tão a mostra, o trabalho funciona, como uma espécie de célula ou núcleo referente ao ato de trabalhar, talvez uma representação icônica do trabalho e sua relação com o espaço institucional, empresarial, funcional. A economia da forma se dá pela própria austeridade de um fazer econômico em tudo: tanto nos materiais, como em seus procedimentos, prioriza-se o mínimo necessário, o suficiente apenas para seu estabelecimento. Assim o trabalho e sua economia operam como signos de Trabalho e Economia, sem que, no entanto, percam sua identidade de forma."

8: "A relação de tensão, em relação ao espaço, evita a abstração requerida pelo capital, sempre necessária para que a mercadoria não se identifique com seu fazer, o que exporia sua contradição." 
desconfiar de sua possibilidade crítica.") agora é coerente que eu duvide da possibilidade de que o trabalho realmente tenha atingido tal ponto de desideologização. É provável que apenas este mesmo grupo treinado pudesse distinguir este contraste negativo.

Por outro lado, a possibilidade desta representação não se aplicaria a qualquer produto de trabalho, ou mesmo a qualquer trabalho de $\operatorname{arte}^{7}$ ? Pelo contrário, sempre vi em muitos trabalhos a tentativa de fazer com que a estrutura ou a forma construtiva apontasse por si mesma para a liberação do espaço institucional, como um espaço livre dentro de um sistema de normas desta crença de autonomia pretensamente liberadora. Acredito que $\mathrm{Wp} / \mathrm{Wp}$ já desmontava de início.

Poderia ter havido, de minha parte, uma idealização em relação à ideologia dominante ${ }^{8}$ : hoje a mercadoria precisaria se identificar com o seu fazer para se auto-valorizar (preço). Em uma discussão recente, Carlos defende que o movimento da ideologia não seria mais o de esconder, mas o de mostrar o "trabalho" para vender mais caro a mercadoria. E eu estaria romanticamente operando com a fase do capitalismo liberal. Ao tratar da Lei Mendonça, tentei apontar para as evoluções ideológicas que interagem com o circuito cultural, e que acho, valem também neste caso. Se o trabalho deixou de ser valor positivado em si, a mercadoria hoje, de modo geral, se valoriza ao expor, não o trabalho, mas o custo em alguns casos. Ao mesmo tempo em que é o consumo o valor predominante, e não mais o trabalho. De qualquer modo não acho que estes processos ocorram de forma homogênea. Curiosamente é na área da cultura como mercadoria que o trabalho me parece ser frequentemente 
9: "Ocorre uma reconexão entre as duas unidades últimas que circulam submetidas ao funcionamento do capital: o trabalho e a mercadoria. O discurso assim as apresenta, como duas pontas de um processo que perseguem uma a outra. São, contudo, partes de um mesmo corpo, faces da mesma moeda; se tudo pode ser convertido em valor trabalho, também tudo pode ganhar aparência de mercadoria sem passado, origem ou razão. Aqui, a obra de arte, já assimilada socialmente como uma espécie de mercadoria líder, como algo cujo preço de funcionamento é exatamente sua supervalorização, como algo que "naturalmente" estaria ali para que todas as relações de trabalho sejam legitimadas, como expressão do papel conciliatório da cultura, se volta para o espectador como mercadoria que trai seu destino, que revela seu processo de constituição, antes embutido, rascunho apagado da forma final. Volta-se como uma decepção, uma obra que fracassa em justificar o quotidiano de trabalho, contrariando a esperança de que o tempo entregue ao trabalho dê algum resultado: não há resultado apresentado por estas formas, há só um retorno ao seu processo de constituição, dirigindo a percepção do sujeito para os processos em que está inserido. Uma antivitrine, que ao abarcar a passagem, pretende voltar o olhar do passante para sua própria condição.

Se trabalho e mercadoria perfazem circuitos continuamente, impulsionados por tal ritmo peculiar, o fazem como que espelhados, representados pela moeda. Este signo universal apenas mantém seu poder de significação enquanto mantiver sua capacidade de circulação. Talvez seja esta a circulação de que sente falta o indivíduo que percorre o corredor de $\mathrm{Wp} / \mathrm{Wp}$. Rodeia hesitante o produto de um esforço inútil, a reparar na precariedade da estrutura, sem nunca ser coberto pelo brilho que o faria semelhante ao dinheiro."

10: "Wp/Wp não se oferece como um espaço convenientemente acolhedor, e embora não se coloque de forma tão cindida com seu entorno, como um cenário fechado, também se fecha para passeios do sentir, também se coloca como limite. Este limite abrange a circulação do espectador. Caminha-se, neste caso, no limite entre trabalho e espaço, 
restaurado como valor estético autônomo, que passa a agregar valor econômico aos produtos culturais, o que não me parece ocorrer na maioria dos segmentos produtivos.

Em “Talvez seja esta a circulação de que sente falta o indivíduo que percorre o corredor de Wp/Wp" talvez deva refazer a sentença trocando "indivíduo" por "sujeito", ou ao menos atenuar a afirmação, que pode ser entendida como uma projeção redutora das possibilidades de percepção do expectador, como se este fosse um personagem subestimado de saída. Mas eu me referia a uma forma de percepção disseminada culturalmente (uma espécie de emplastro Brás Cubas que paira como valor pelo desejo comum). A pretensão de definir assim esse sujeito seria facilmente evitada se eu substituísse a ultima frase por algo como "[...] que o manteria em seu impulso", ou "em movimento".

Ainda penso que um mérito primeiro do trabalho era a estratégia de se situar entre formas reconhecidas, sem, no entanto, fazer-se reconhecer por alguma em especial: a descrição já determinava esta negação sucessiva de contornos reconhecíveis: "não funcionava como cerca, nem como suporte, nem como...". Porém esta negação ainda continuava em relação a qualquer categoria cristalizada para a produção artística: não mostrava o caráter cenográfico de uma instalação, não oferecia o aconchego de um espaço "convenientemente acolhedor" ${ }^{10}$, não se colocava como forma escultórica, por conta da conexão entre a estrutura e a superfície brilhante. Assim o trabalho acontecia ao falhar sucessiva e alternadamente em campos ou espaços próxi- 
por um corredor que parece estar prestes a ser eliminado pelo avanço da estrutura interna. Esta sensação, contudo, não se deve a nenhum efeito dramático ou ótico. Pelo contrario, se deve a percepção óbvia de seus materiais; ripas de madeira pregadas de forma simples e metódica, assim como o vazio entre elas, que afasta qualquer participação entusiasmada ou interatividade ilusória. Transforma o passar em um andar envergonhado. Aponta para o ato de circular como sendo de uma finitude pouco dignificante. Com isso contribui para que se revele a glamourização forçada do quotidiano circulatório dos espaços do prédio. Pela circulação é que se dá o ritmo, e pela impressão deste ritmo, a eternização de uma condição de permanente precariedade. O sujeito que se via triunfante por obedecer a esta lógica, por ser submetido à circulação perene, que se justifica como meio e fim para tudo, se vê então num circular depressivo, sem missão. Parece-me que em WP/WP, o lugar do sujeito é desvelado e, ao mesmo tempo, proposto por este percurso, por esta desaceleração melancólica Não me refiro, evidentemente, ao ritmo físico do visitante que pode até caminhar mais rápido. Isto só poderia revelar o incômodo do trajeto, ou mesmo uma relação viciada de não leitura, de uma busca por signos imediatamente eficientes, freqüente tanto nas auto-estradas quanto nos museus, mas que aqui é frustrada e termina sem resposta a cada vez que o percurso é realizado. WP/WP aponta para uma condição do sujeito de todos estes espaços que se instrumentalizam, mais do que uma critica ao espaço expositivo institucionalizado. A própria precariedade deste espaço específico (ArteNexo), sua tentativa tosca, embora amplamente divulgada, de se apresentar como um "cubo branco", signo de sofisticação, é absorvida pela intervenção como parte da estratégia; o prédio todo é frustrado em sua tentativa de exercer o papel a que se propõe, o de acolher e delimitar Cultura. Ocorre um refreamento do sujeito para quebra da condição rítmica do discurso em que se insere.

As lacunas deixadas pelo trabalho, sua falta de comando em relação ao expectador, ao mesmo tempo em que não lhe deixa alternativa, sua recusa em legitimar-se como "obra de arte", sua precariedade, são todas reveladoras da precariedade de seu entorno, da falsa liderança exercida por uma arquitetura autoritária, que é valorizada hoje como reafirmação de um gosto padronizado.

O gosto formado e formador da ideologia dominante é questionado, sem que se proponha sua substituição por alguma outra forma de cunho apaziguador ou conciliador. O juízo nega que a forma seja arte, e a forma parece negar que o que lhe serve de entorno seja vida." 
mos de si, para que escavasse o seu próprio. Ser definido pelo que não foi em vários momentos diferentes, e ainda agora, como acontece neste espaço discursivo.

Após mais uma leitura, fico com a impressão de que gasto nestas considerações um bom tempo defendendo a possibilidade que havia em $\mathrm{Wp} / \mathrm{Wp}$ de apontar contradições, de revelar tensões que o aparelho cultural com o qual lidava pretendia negar. E também de evitar a relação de cumplicidade que este aparelho reservava para o trabalho, subestimando o antagonismo que poderia haver entre qualquer resultado e a situação que administrava. 

Mas como leitor de meus argumentos, tenho a sensação de que à medida que estes se conectam para meu próprio convencimento da força de $\mathrm{Wp} / \mathrm{Wp}$, vai se perdendo a força do relato como lugar de transformação. A lógica, que constrói a intervenção como forma potente, vai minando a narrativa que poderia conter lições valiosas e cuja forma não cabe no formato prescrito para conclusões.

Por qual critério pode-se avaliar $\mathrm{Wp} / \mathrm{Wp}$ ? Penso que o trabalho terá tido algum interesse se houver ocupado seriamente o lugar da impossibilidade que enfrenta qualquer intervenção artística em dar resposta definitiva às tensões contraditórias de que participa social e politicamente. Este relato, apesar de inconclusivo a respeito deste critério, pretende ao menos confirmar a resistência de $\mathrm{Wp} /$ $\mathrm{Wp}$ ao movimento culturalmente administrativo que queria lhe impor um lugar social predeterminado e instrumental (o Workplace ainda me aparece como uma metáfora invo luntária desta visão totalitária, ao mesmo tempo em que era agente participante de sua lógica - quase um aparelho metonímico). Muito embora este mesmo relato, que se supõe crítico desta experiência, a tenha sublimado para tornar a solidificá-la em um prolongamento deste lugar socialmente predeterminado para a arte enquanto representação: a academia. Nenhum pecado nisso, já que tais prolongamentos agem de forma integrada, como estará integrada a eles qualquer possibilidade de intervenção nestes espaços.

Mas ainda vale explorar a dúvida da possibilidade de resistência neste desdobramento de $\mathrm{Wp} / \mathrm{Wp}$, tanto quanto em seu momento inicial como intervenção. E a leitura, o lugar construído pelo texto, é a forma que garante o exercício da dúvida.

Pois que, conforme posiciono linearmente cada uma das palavras que escolho, cavo o caminho pelo qual obrigo 
11: "É por este percurso obrigatório existente em Wp/Wp que se aproximam e se conectam os dois sujeitos possíveis de que tratei no início do texto: o que se fundaria pela descrição e o que, através do primeiro, se tornaria possível. Tanto a narrativa que tenta dar conta da experiência passada no espaço da intervenção quanto a experiência proposta pela própria narrativa tomam forma pelo tempo. Por uma sucessão de passos, dados pelo corredor que resiste em meio ao espaço expositivo e a estrutura interna, é que se forma o lugar do sujeito em $\mathrm{Wp} / \mathrm{Wp}$, da mesma forma que, pela sucessão das partes, este se forma na narrativa que se inicia com a descrição da intervenção e continua por estas páginas. É a narrativa que reinstaura o espaço do trabalho. O texto é o lugar ocupado por ele desde então." 
meu leitor a avançar, como acontecia em Wp/Wp.

E meu leitor avança repetindo comigo as palavras que escolhi para ele, de forma a estarmos eu e ele, simultaneamente, neste mesmo lugar/forma que é o texto. Ele caminha em direção às minhas conclusões como eu antes dele, por meio da linearidade da escrita. E as conclusões, que deixo ao fim do caminho, são resultado desta linearidade, são concebidas conforme se concebe a estrutura deste mesmo texto $^{11}$.

Se há pertinência em falar do texto como o lugar do trabalho, esta possibilidade se torna mais apreensível neste ponto. A prática do relato parece ter reelaborado os espaços do Artenexo (eles ainda me aparecem como aspirantes a uma abstração limpa, pura, embora esta aspiração se voltasse contra a provável riqueza presente em sua especificidade, que negava a si mesma) a ponto de reinaugurálo como lugar de experiência. A leitura do relato oferece a possibilidade de vasculhar este lugar, ao mesmo tempo em que o reconstrói.

Talvez o maior indício de uma tentativa de resistência a se formar de dentro do texto seja minha ação sobre o nome de Workplace, tomada a posteriori, durante a recuperação da memória que ativei para o projeto de mestrado, quando passei a chamar o trabalho de Workplace/Werkplaza. Neste momento o trabalho iniciava sua existência como relato. $\mathrm{O}$ próprio nome do trabalho passou a propor este movimento que eu quis ter visto na intervenção, o de apresentar mimeticamente um discurso para reescrevê-lo, contrapor-se a ele, alinhá-lo a um espelhamento, resultado da própria aleatoriedade que produziu o nome do edifício.

Isto parece apontar tanto para a possibilidade de resistência dentro do discurso, quanto, talvez paradoxalmente, para a arbitrariedade do ato de nomear, e assim definir, de- 

limitar, projetar o espaço da intervenção em contraste com o espaço anterior. Por isso a manutenção da dúvida.

Mas também este relato se constrói ocupado em estar consciente de si e de suas possibilidades de leitura, neste outro contexto, o da universidade. E também este texto poderá ter ocupado seriamente o lugar da impossibilidade que enfrenta qualquer intervenção artística em dar resposta definitiva às tensões contraditórias de que participa social e politicamente. E com sorte, esta narrativa terá construído este outro lugar do trabalho, e a escrita deixará entrever por sua estrutura, como em $\mathrm{Wp} / \mathrm{Wp}$, este objeto que falta, que escapa, por meio da forma assimilada de um pequeno livro. 
Referências bibliográficas:

ADORNO, T. "Teoria Estética". São Paulo: Martins Fontes, 1982.

ALTHUSSER, L. "Sobre a Reprodução". Petrópolis: Vozes, 1999

ARANTES, O. "Urbanismo em Fim de Linha". São Paulo: Editora da Universidade de São Paulo, 2001

ARANTES, O. "Depois dos Modernos". São Paulo: Editora da Universidade de São Paulo, 2000

AUGÉ, M. "Não-Lugares; Introdução a uma Antropologia da Supermodernidade". Campinas: Papirus, 1994

BENJAMIN, W. "O Narrador, Considerações sobre a Obra de Nicolai Leskov" in "Obras escolhidas". São Paulo, Brasiliense, 1985

BORGES, J. L. "O Fazedor". São Paulo: Difel, 1984

BORGES, J. L. "Livro de Areia". Lisboa: Editorial Estampa, 1975

BOURDIEU, P. “A Economia das Trocas Simbólicas”. São Paulo: Perspectiva, 2005

BOURDIEU, P. “La Distinction”. Paris: Ed. De minuit, 1979

BRANDÃO, H. N. "Introdução à Análise do Discurso". Campinas: UNICAMP, 2004 
BURGIN, V. "Olhando Fotografias" in FERREIRA, G e COTRIM, C. seleção "Escritos de artistas; anos 60 e 70”. Rio de janeiro: Jorge Zahar Editor, 2006

CANDIDO, A. [et al.]. "A personagem de Ficção". São Paulo: Perspectiva, 2005

CARCANHOLO, R. A. "O Capital Especulativo Parasitário: Uma Precisão Teórica sobre o Capital Financeiro, Característico da Globalização". para UFES

CHAUÍ, M. de S. "Cultura e Democracia: o discurso competente e outras falas". São Paulo: Ed. Moderna, 1981

CRIMP, D. "Sobre as Ruínas do Museu". São Paulo: Martins Fontes, 2005

EAGLETON, T. “A Idéia de Cultura”. São Paulo: UNESP, 2005

EAGLETON, T. "A Ideologia da Estética". São Paulo: Jorge Zahar, 1993

FIORI, J. L. "Brasil no Espaço". Petrópolis: Vozes, 2001

FIX, M. "Parceiros da Exclusão". São Paulo: Boitempo, 2001

FLUSSER, V. "Elogio da Superficialidade". São Paulo: Annablume, 2008

FLUSSER, V. "Filosofia da Caixa Preta; ensaios para uma futura filosofia da fotografia". Rio de Janeiro: Relume Dumará, 2002

FLUSSER, V. "Língua e Realidade". São Paulo: Annablume, 2004 
FOUCAULT, M. “As Palavras e as Coisas”. São Paulo: Martins Fontes, 1967

FOUCAULT, M. A Ordem do Discurso". São Paulo: Loyola, 1996

FOUCAULT, M. “A Verdade e as Formas Jurídicas". Rio de Janeiro: Nau, 2005

FOSTER, H. "Recodificação; Arte, Espetáculo, Política Cultural". São Paulo: Casa Editorial Paulista, 1996

HARVEY, D. "Condição Pós-Moderna”. São Paulo: Loyola, 1996

HARVEY, D. “A Produção Capitalista do Espaço”. São Paulo: Annablume, 2005

HARVEY, D. "Los Límites del Capitalismo y la Teoria Marxista", México: Fondo de Cultura Econômica, 1991

JAMESON, F. "A Cultura do Dinheiro". Petrópolis, Rj: Vozes, 2001

MALRAUX, A. “O Museu Imaginário”. Lisboa: Edições 70, 1965

MARX, K. "O Capital", São Paulo: Difel, 1980

MEIRELES, C. "Cildo Meireles". London: Phaidon, 1999

MONEGAL, E.R. "Borges, Uma Poética da Leitura". São Paulo: Perspectiva, 1980

NAVES, R. “A Forma Difícil”. São Paulo: Ática, 1996 
O'DOHERTY, B. "No Interior do Cubo Branco". São Paulo: Martins Fontes, 2002.

RIVITTI, T. de S. “A idéia de circulação na obra de Cildo Meireles”, Dissertação de Mestrado para USP, São Paulo, 2007.

SMITHSON, R. "Robert Smithson, The Collected Writtings" Nova Iorque: NYUP, 1996

TODOROV, T. “Os Gêneros do Discurso”. São Paulo. Martin Fontes, 1980

TRACY, D. De. “Élements D`Ideologie”. Paris: Libraire Philo sophique J. Vrin, 1970

WILLIAMS, R. “Cultura”. Rio de Janeiro: Paz e Terra, 1992

WU, C. "Privatização da Cultura, a intervenção corporativa na arte desde os anos 1980. "São Paulo: Boitempo, 2006 


\section{Anexos}



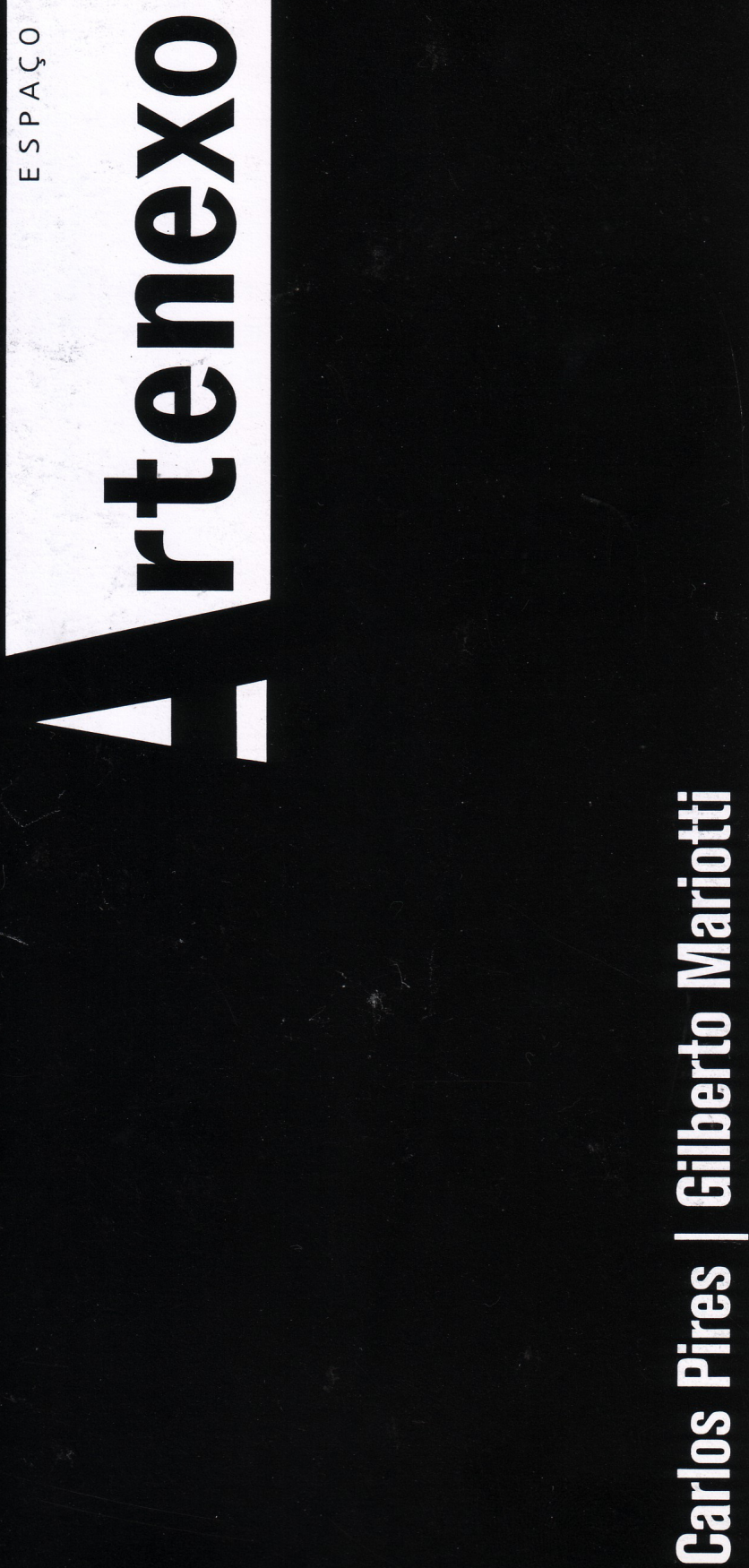


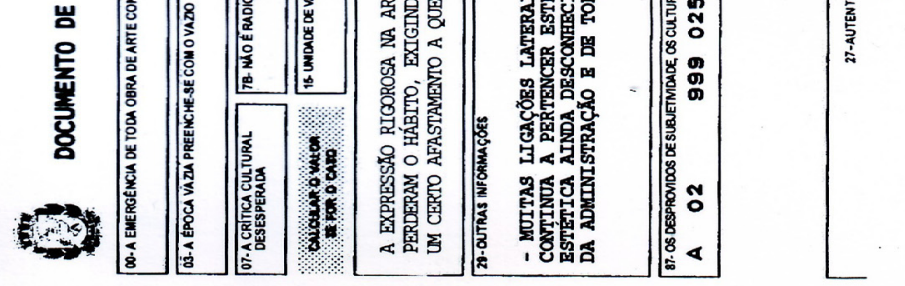

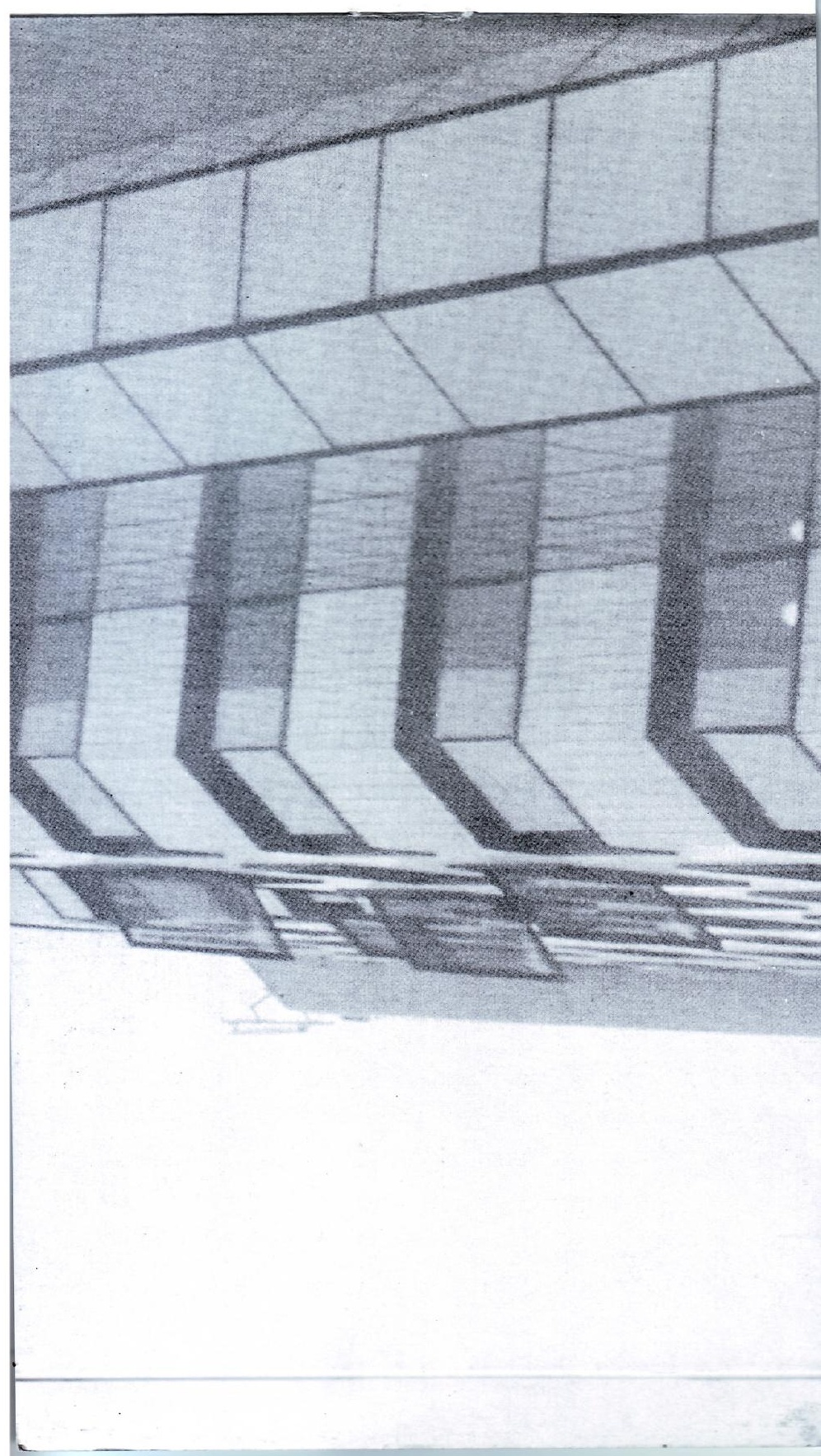




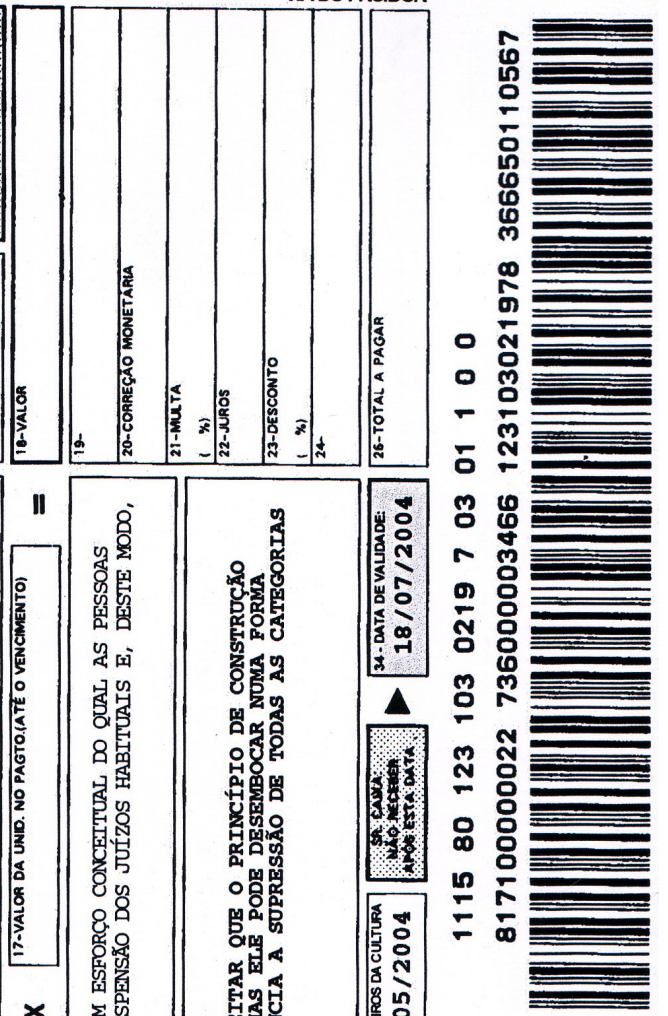

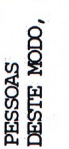

द्वे क्षे

穴最

8舄

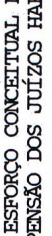

官窟

ชุष

密

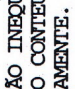

通是

综

谣

造

国瓷

最贯告

造圄

ज牲

젓요

迢运

息畏

\&्ये열

눈롱

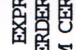

喵罗

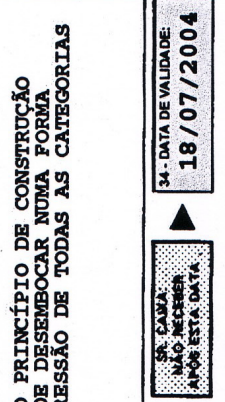

여ㅇㅕㅕㅁ

总问

为乐

봅분

罂究

है⿴囗十

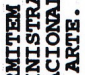

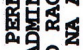



분중

短最

웡정

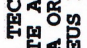

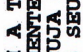

하의.

oํㅓํㅇํㅇ

붒붕우

国实圆

s解的

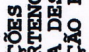

论俰

句能

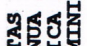

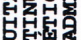

部弱

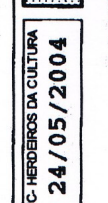

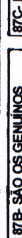

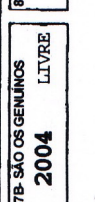




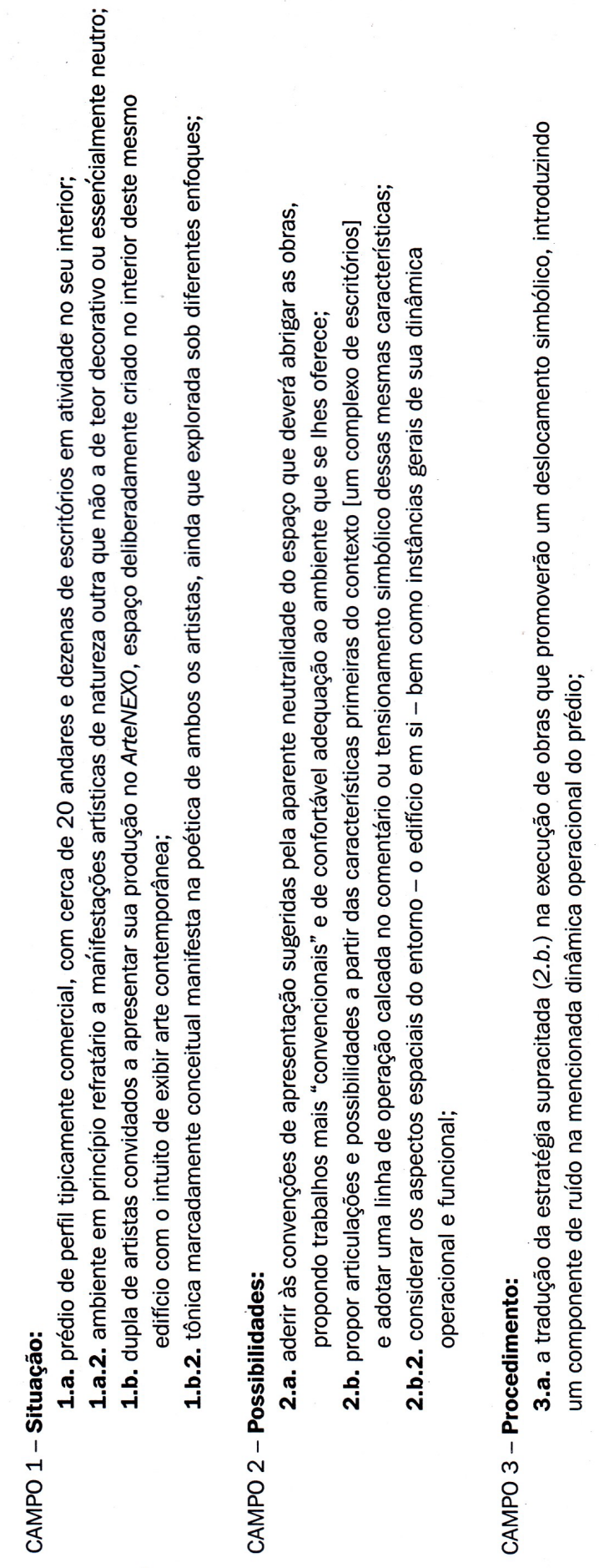



FEODOR ADORNO

INIMA MORALIA, TEORIA ESTETICA

VADOFRUDOR
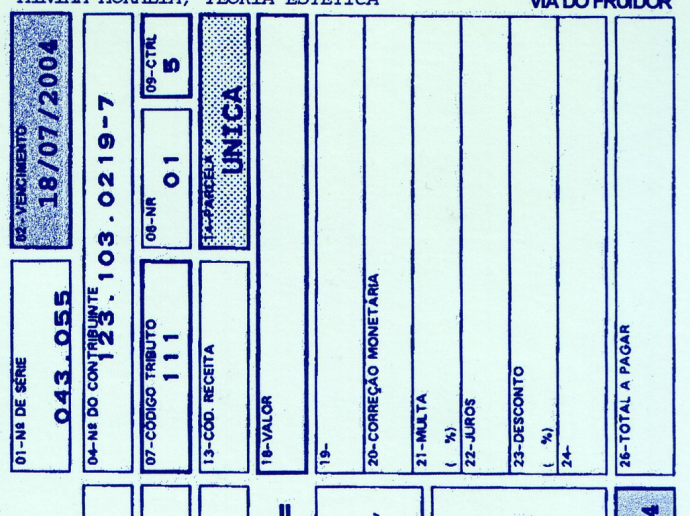

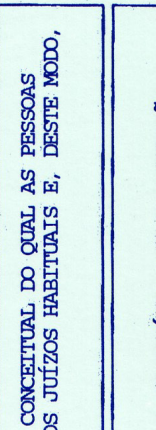

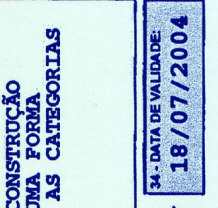

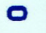

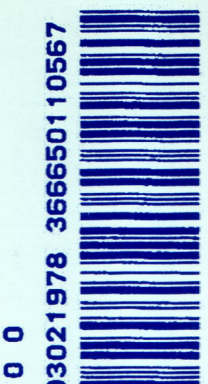

음

$-$

5

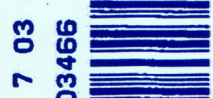

ก

๑

ริ

吕

\%

的

의우

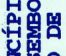

붐의

임영

을

圈质

究㩆

这息

है.

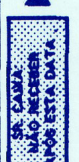

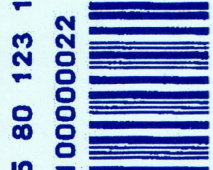

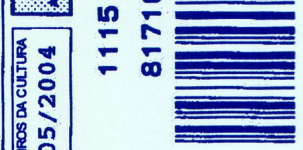

इू है

छुष

客

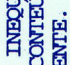

\&

咚客

봉

谣

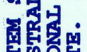

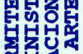

番影

ธै।

붕중

官瓷

월

急的

毁屠

웡ำ

影留

国狊

oํํำ

불붕요

鲴臣

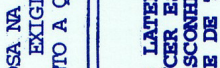

\%

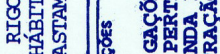

군

品能

ชธ์

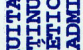

论败合

逼突

通

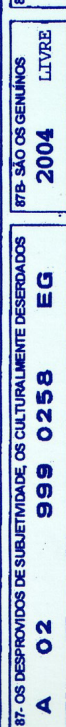

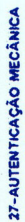




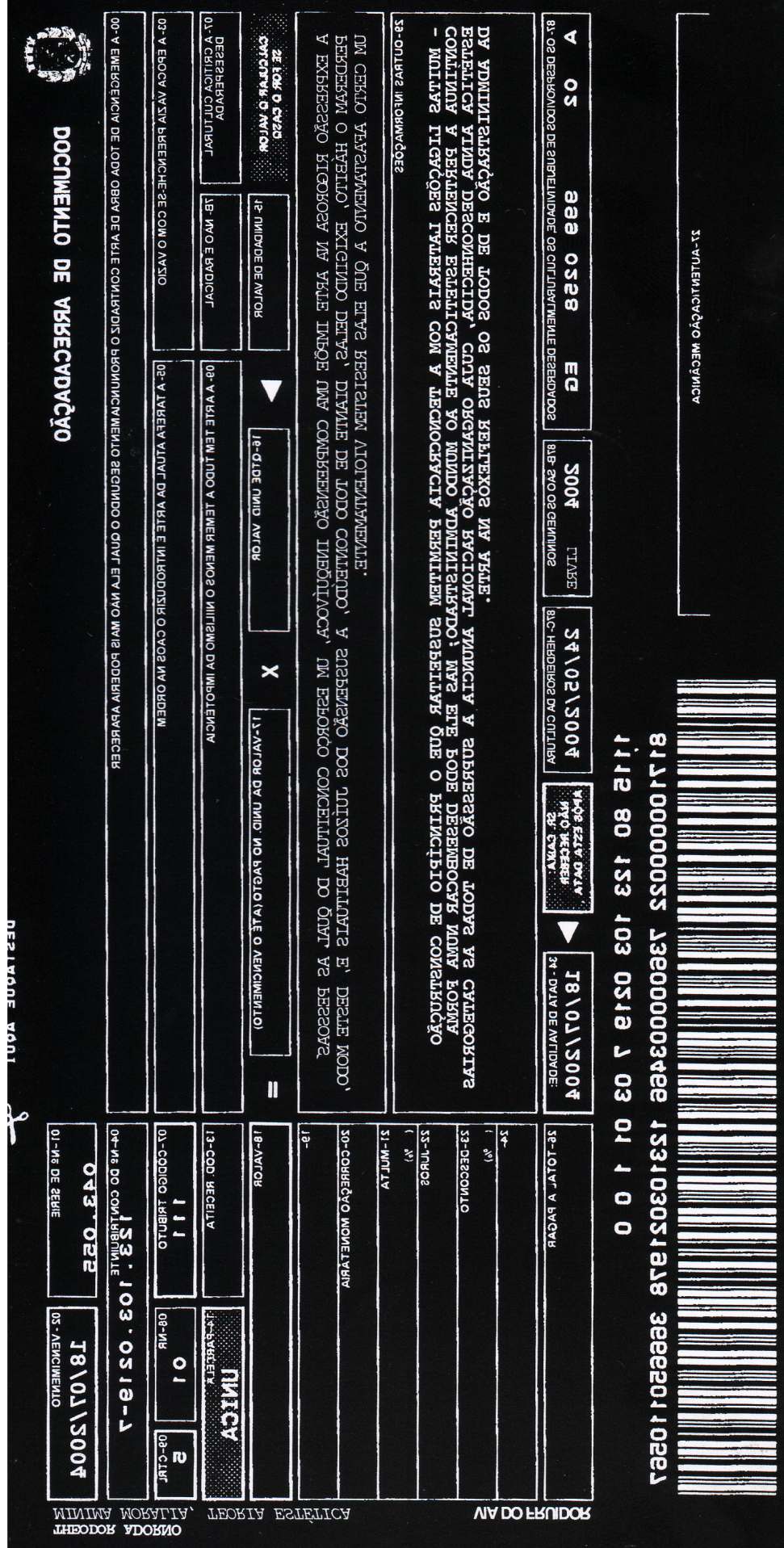





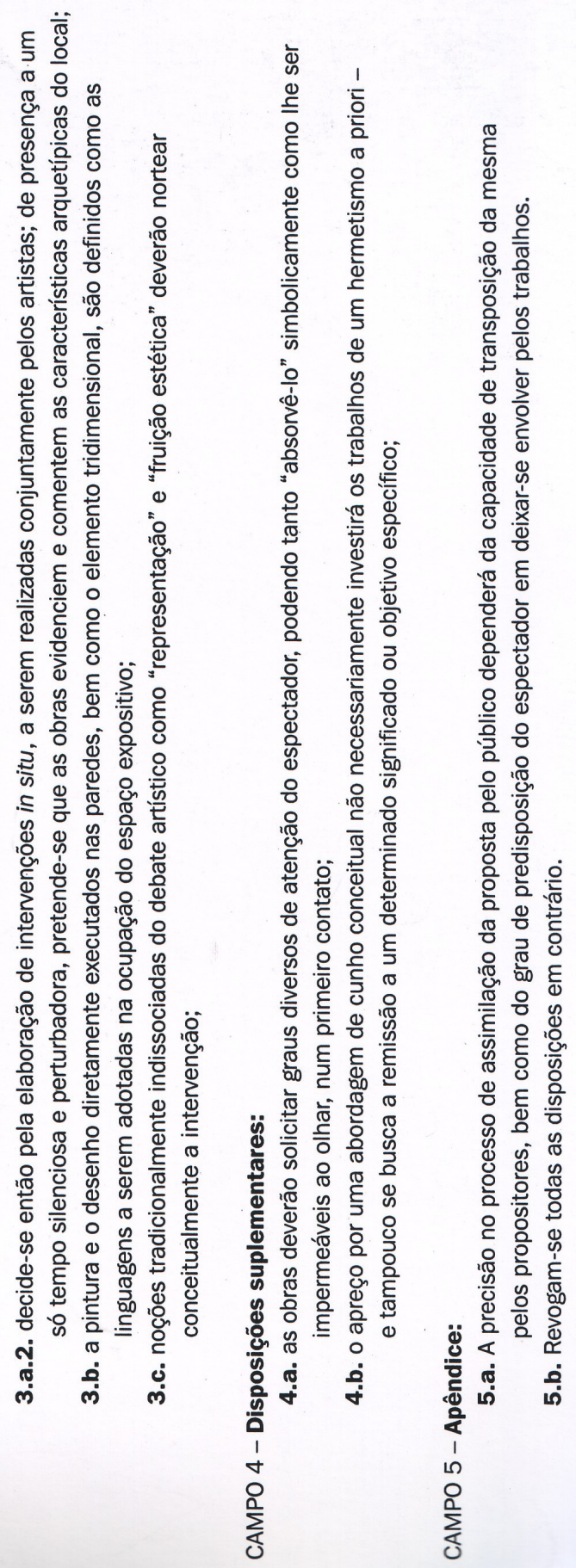




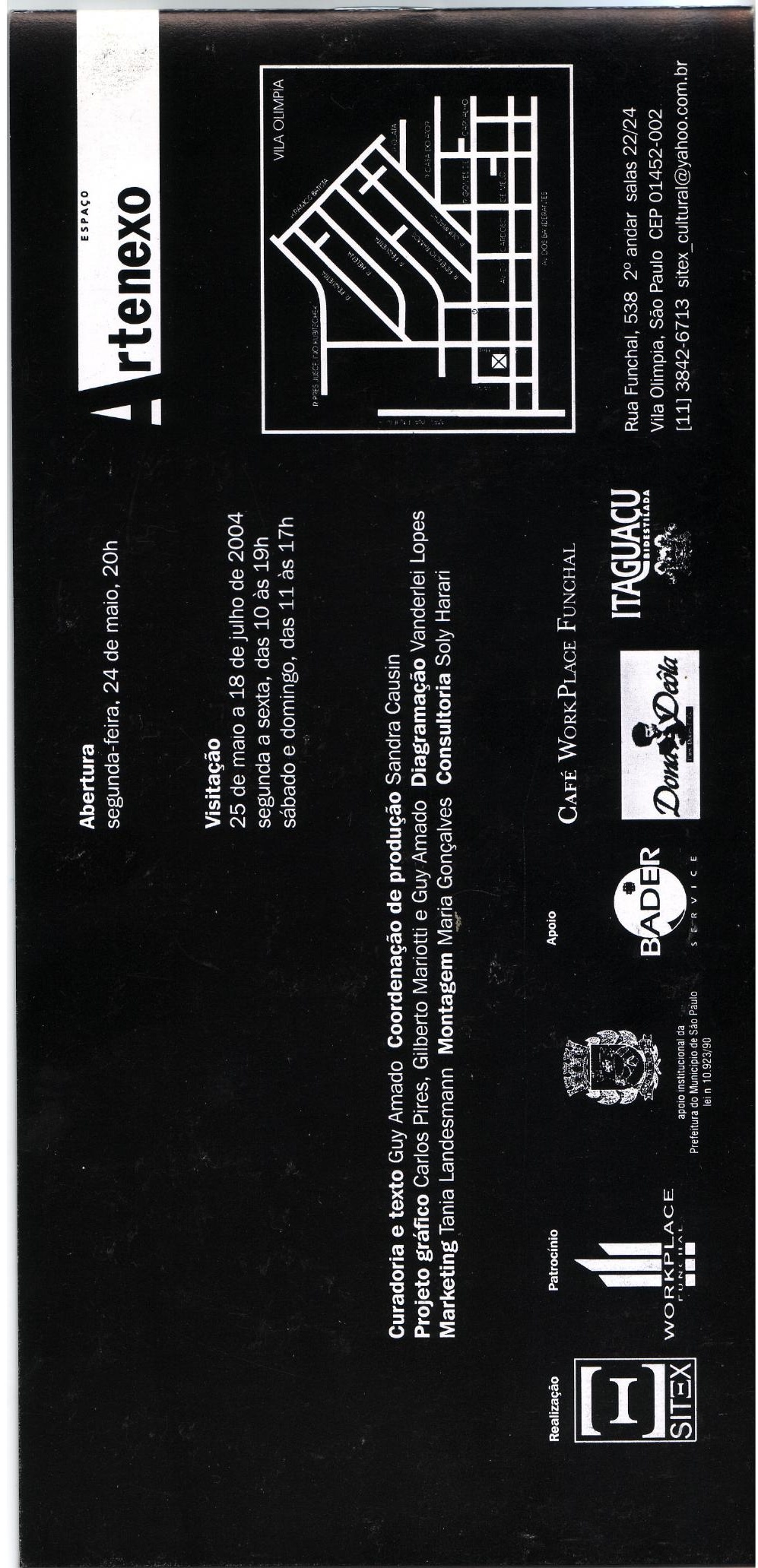


Antes da exposição que apresentamos, foco do estudo de Gilberto, estava interessado em tentar criar um espaço em que pequenas alterações nele mudariam a atenção do observador ou, especificando um pouco mais, colocassem aquele que estava ali em um tipo de situação em que certa impossibilidade da, por falta de termo melhor, experiência estética, reiterada pelo próprio trabalho, em alguma medida se negava e se tornava possível sem cair, ou pretendendo não cair, em mais um bobo reencantamento do mundo. Como essa idéia surgiu: fiz uma exposição em que apresentei seis maquetes com seis diferentes ocupações desse mesmo espaço e, em determinado momento, como me parecia previsível, uma maquete apresentava a própria exposição criando certa duplicação temporal bem lugar comum que temos quando nos situamos em um mapa ou coisa assim. Só que nesse momento era possível ver certas irregularidades do espaço "real" que mostravam certos elementos, visíveis em pequenos pedaços na base que apoiavam as maquetes, que apareciam como marcas, em uma última maquete, que não se podia ver pois os blocos expositivos estavam em cima. Dessa brincadeira, que aliás tentava, sem conseguir na grande maioria dos casos, trazer um outro grau de atenção ao trabalho - a maioria dos comentários apontavam infelizmente para o lado "cool" de expor maquetes e negar a possibilidade de qualquer experiência estética - busquei outra forma de realizar aquela "sensação temporal" estranha sem usar maquetes. Bater na dimensão excessivamente projetiva de grande parte da arte contemporânea - ou para o fato das realizações serem maquetes agigantadas - começou a parecer pouco. Fiz, então, alguns trabalhos que aconteciam em diferentes lugares de uma mesma exposição em que plantas e pedaços do espaço miniaturizados buscavam algo na direção que me interessou no trabalho anterior. Nessas plantas e trabalhos usei o recurso de mudar o branco para causar as pequenas irregularidades, branco que acabava por ser o lugar ausente, uma espécie de pegada, de quem olhava a última planta - não bem solucionada na coerência da forma, tra- 
zia certo lugar comum publicitário para um trabalho que mesmo com certo humor se pretendia composto por materiais de outra origem - tentei limpar o aspecto "cool" das maquetes e caí, sem querer, em certo terreno talvez pior. Essa ironia me levou a pensar em como incorporar esses elementos que pareciam postiços no trabalho das plantas com um grau maior de verdade em um trabalho. Pensei então em um espaço em que certo lugar comum de construções populares, hospitais e escolas - aquela faixa de cor brilhante que se pinta nas paredes do chão até mais ou menos um metro para, talvez, facilitar a limpeza - entrasse como um elemento compositivo que funcionasse, com perdão do clichê, contaminando os objetos expostos e, por último, o "observador" na pegada que ele deixaria impressa em um cubo limpo que poderia usar de apoio para enxergar algo que estava fora do campo de visão sobre um cubo agigantado - outra pegada impressa no branco que "contaminava" os objetos da sala. A preocupação com a luz que anulava a diferença dos brancos até o observador entrar e começar a perceber essas pequenas diferenças causou um curioso julgamento de fora da sala que mal foi visitada: as pessoas passavam, colocavam a cara para dentro e comentavam coisas nessa direção: "aí não tem nada, vamos para a outra" ou, quando era um observador do ramo, "mais um trabalho minimal" etc. A exposição que o Gilberto nomeou WP/WP aconteceu dentro de um projeto que teve vida curta chamado artenexo. Como fomos chamados para ele e colocados juntos em seu programa, resolvemos tentar fazer um trabalho que se mantivesse íntegro em relação aquela situação, ou que no mínimo não nos envergonhasse seis meses depois, e que mantivesse a integridade dos dois trabalhos. Começamos, então, a pensar em algo. Para mim estava claro que a direção tinha que se dar a partir do trabalho anterior dentro da brincadeira com os "dois espaços" dados pela diferença sutil entre brancos e para o Gilberto, acredito, dentro da sua pesquisa com pintura. Fomos visitar o espaço, um centro comercial com salas de escritório que disponibilizou duas para o projeto. A primeira sensação, acho que de ambos, foi o pé direito baixo dessas construções. Começamos em cima disso a pensar. 
Precisávamos deixar essa sensação um pouco pior, o branco brilhante suspenso foi o elemento que talvez desse esse efeito. Só que precisávamos de algo que o mantivesse suspenso. Pensamos, então, na estrutura central feita com o mínimo de elementos para mantê-la em pé. Mas essa, frágil, não conseguia cumprir sua função, a massa branca a atravessa na parte superior. Mesmo ocupando o espaço repetindo um desenho funcional considerando a possibilidade mais simples para apoios de sarrafos de madeira, isso ficou com uma aparência precária - um observador falou em barraquinhas de festa junina de interior, outro, na parte de baixo de um píer. Essa aparência precária não estava completamente fora do nosso horizonte, tinha que ser uma estrutura de sustentação que não conseguia sustentar a massa invisível branca. $\mathrm{Na}$ minha ingenuidade, achei que o cuidado, entre todos os outros, de procurar uma correspondência ao brilho do branco na madeira fosse suficiente para evitar essa leitura, o que obviamente não aconteceu como pude ouvir em alguns depoimentos. A alcunha de minimal apareceu em outros, como no trabalho anterior. Mas alguns depoimentos, de pessoas que não eram do ramo, saíram desses lugares comuns culturais e propuseram leituras interessantes: o observador que falou na estrutura de um píer, notou, em seguida, que as coisas parecem acontecer no píer, que estamos nessa subvida a espera daquilo que não alcançaremos; ou outro que questionou certa obsessão dos "artistas" com a reiteração da forma de estrutura, como se a lógica ou racionalidade no trabalho fosse mais uma espécie de ritual do que um elemento orientado para algum meio de esclarecimento. A realização desse que foi meu último trabalho - e, ao que parece, continuará sendo - mais essas trocas que nos recolocam de frente com o que fizemos, formam o resto dessa interessante, do ponto de vista individual apenas, e fracassada experiência. 

Agradeço muitíssimo a:

Ana Tavares e Martin Grossman, pela confiança; Carlos Pires, pela possibilidade de discussão; José Antonio Pasta e Sônia Salzstein, pela leitura para o exame de qualificação; Renata Guarido, pela crítica atenciosa; Marlito de Souza e Rodrigo Naves, pelas sugestões; Iuri Pereira, pela escuta; Néstor Gutiérrez, pela interlocução; Santiago Reyes, pelo ânimo; Ionit Zilberman, por reclamar de minha ausência; Janaina Navarro, por todo o apoio no dia do perdedor; Guy Amado, pelo convite que nos fez como curador do Arte nexo; Gilberto e Eni Mariotti, por tudo. E a Inês, por inventar comigo o mais feliz dos motivos para minha falta de concentração na revisão deste trabalho: nossa querida Olivia. 